\title{
The AMPK-MNK1 signaling axis
}

Citation for published version (APA):

Zhu, X. (2016). The AMPK-MNK1 signaling axis. [Doctoral Thesis, Maastricht University]. Maastricht University. https://doi.org/10.26481/dis.20161020xz

Document status and date:

Published: 01/01/2016

DOI:

10.26481/dis.20161020xz

Document Version:

Publisher's PDF, also known as Version of record

\section{Please check the document version of this publication:}

- A submitted manuscript is the version of the article upon submission and before peer-review. There can be important differences between the submitted version and the official published version of record.

People interested in the research are advised to contact the author for the final version of the publication, or visit the DOI to the publisher's website.

- The final author version and the galley proof are versions of the publication after peer review.

- The final published version features the final layout of the paper including the volume, issue and page numbers.

Link to publication

\footnotetext{
General rights rights.

- You may freely distribute the URL identifying the publication in the public portal. please follow below link for the End User Agreement:

www.umlib.nl/taverne-license

Take down policy

If you believe that this document breaches copyright please contact us at:

repository@maastrichtuniversity.nl

providing details and we will investigate your claim.
}

Copyright and moral rights for the publications made accessible in the public portal are retained by the authors and/or other copyright owners and it is a condition of accessing publications that users recognise and abide by the legal requirements associated with these

- Users may download and print one copy of any publication from the public portal for the purpose of private study or research.

- You may not further distribute the material or use it for any profit-making activity or commercial gain

If the publication is distributed under the terms of Article $25 \mathrm{fa}$ of the Dutch Copyright Act, indicated by the "Taverne" license above, 


\section{The AMPK-MNK1 signaling axis}


(C) Xiaoqing Zhu, 2016. For all articles published, the copyright has been transferred to the respective publisher. No part of this publication may be reproduced, stored in a retrieval system or transmitted in any form by any means, without prior written permission from the author, or when appropriate, from the publisher.

ISBN: 978-90-9029980-8

Cover design: Xinjie Zhan (詹金金婕), Xiaoqing Zhu (朱小庆) \& Tomasz Karawajczyk Layout: Tomasz Karawajczyk 


\title{
The AMPK-MNK1 signaling axis
}

\author{
DISSERTATION \\ to obtain the degree of Doctor at Maastricht University, \\ on the authority of the Rector Magnificus, Prof. dr. Rianne. M. Letschert, \\ in accordance with the decision of the Board of Deans, \\ to be defended in public
}

On Thursday, October $20^{\text {th }} 2016$ at $10.00 \mathrm{hrs}$

by

\section{Xiaoqing Zhu}

Born on May 13th 1987 in Shandong China 
Supervisor:

Prof. dr. J.F.C. Glatz

\section{Co-supervisors:}

Dr. D. Neumann

Dr. J.W. Voncken

\section{Assessment committee:}

Prof. dr. R. Shiri-Sverdlov (Chair)

Dr. R.C. Langen

Prof. dr. S. Ludwig (University of Münster, Germany)

Prof. dr. Kei Sakamoto (Nestlé Institute of Health Sciences, Switzerland)

Dr. T. Welting 


\section{Contents}

Chapter 1 General Introduction

Chapter 2 In vitro methods to study AMPK

Chapter 3 AMP-activated protein kinase upregulates MAP kinase interacting serine/threonine kinase 1a-dependent phosphorylation of eukaryotic translation initiation factor $4 \mathrm{E}$

Chapter 4 AMPK and ERK control MNK1a-mediated elF4E phosphorylation in cell survival

Chapter 5 A complex of AMPK, MNK1a and EGR1 controls metabolic stress-induced transcriptional responses

Chapter 6 General discussion

Appendices

Summary

Samenvatting

总结

Valorization

Curriculum vitae 123

Acknowledgments 



\section{Chapter 1}

\section{General Introduction}
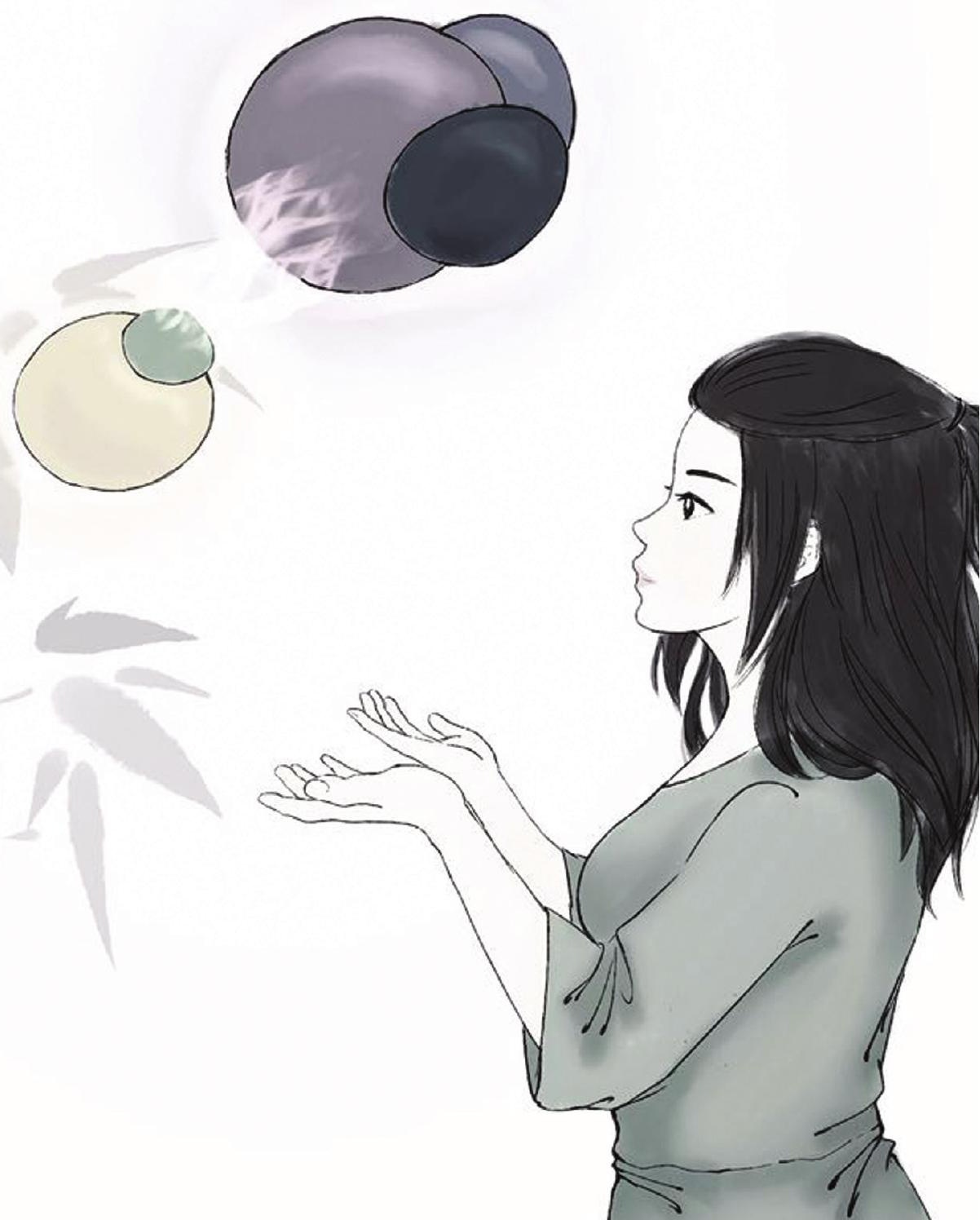


\section{Introduction}

For any living species, energy homeostasis is crucial for survival and it is maintained by a balanced regulation between energy intake and expenditure (1). Therefore, living cells also constantly control the energy equilibrium by adjusting the rate of catabolism and anabolism. Upon an energy challenge, cellular ATP is depleted and consequentially the cellular AMP level rises. In decades of study, AMP-activated protein kinase (AMPK) has been established as the principal energy sensor in most eukaryotic cells. In this chapter, the current status of knowledge on AMPK function in relation to cellular energy metabolism will be shortly reviewed before turning to MAP kinase-interacting serine/ threonine-protein kinase 1 (MNK1) as a possible novel downstream target of AMPK. The focus of this thesis is the elucidation of the putative AMPK-MNK1 connection.

\section{AMPK regulation and function}

The heterotrimeric AMPK complex consists of three subunits: a catalytic $\alpha$ subunit and the regulatory $\beta$ and $\gamma$ subunits. In structure, $\alpha$ subunit contains both a serinethreonine kinase domain for activation and an auto-inhibitory domain; $\beta$ subunit tethers $\alpha$ and $\gamma$ subunits; and $\gamma$ subunit carries sequence repeats for adenine nucleotides binding (2). So far, two $\alpha$ isoforms $(\alpha 1, \alpha 2)$, two $\beta(\beta 1, \beta 2)$ and three $\gamma(\gamma 1, \gamma 2, \gamma 3)$ have been identified and they show different expression profiles among animal tissues. In mice and rats, $\alpha 1 / \beta 1$ is more ubiquitous in heart, liver, kidney, brain, spleen, lung and skeletal muscle, while $\alpha 2 / \beta 2$ is most abundant in muscular tissues; $\gamma 1$ and $\gamma 2$ are also widely expressed and $\gamma 3$ is restricted to skeletal muscle (3). Also, AMPK $\alpha 2$ subunit has been implicated in transcriptional regulation for its preferential nuclear localization (4).

For AMPK activation, phosphorylation on Threonine (Thr) 172 residue in $\alpha$ subunit is the main activation step (5). To date, three upstream kinase have been reported for AMPK activation: liver kinase B1 (LKB1), $\mathrm{Ca}^{2+} /$ calmodulin-dependent protein kinase kinase (CaMKK) and transforming growth factor- $\beta$-activated protein kinase-1 (TAK1) (6). During energy stress, caused by e.g. nutrient or oxygen deprivation, when intracellular ATP declines and AMP increases, LKB1 is the major kinase to phosphorylate the activation loop (Thr172) of AMPKa (7). Elevation of intracellular $\mathrm{Ca}^{2+}$ was later shown to also induce AMPK activation via CaMKK $\beta$ (8). Although not much is known yet about TAK1-mediated AMPK regulation, the TAK1-AMPK axis appears implicated in regulating cytoprotective autophagy pathways (9). Structurally, with AMP: ATP ratio shift upon energy depletion, AMPK $\gamma$ subunit shows slight higher binding affinity with AMP, which thus promotes direct allosteric activation and also protects AMPK from dephosphorylation via a conformational change $(10,11)$.

Among chemical compounds for AMPK activation, 5-aminoimidazole-4-carboxamide 


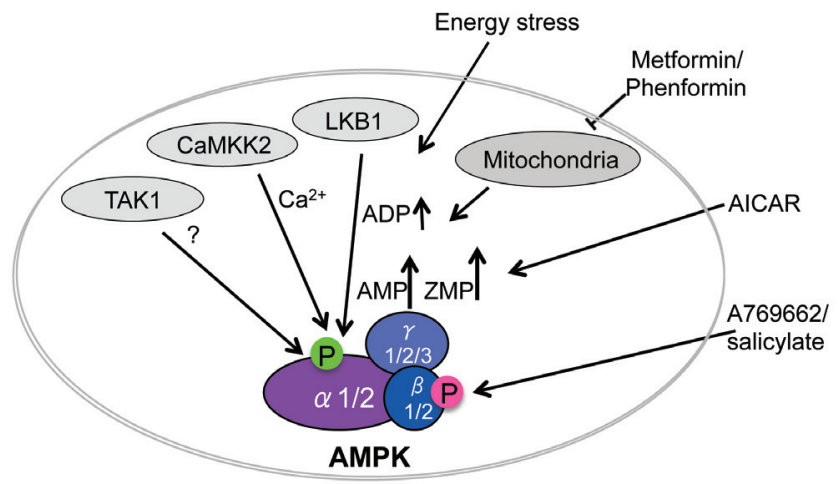

Figure 1. The AMPK heterotrimer and its regulation. AMPK is a heterotrimer with various isoform combinations and AMPK Thr172 phosphorylation (in green) is the main activation step. Upon energy stress, LKB1 is the major kinase for AMPK activation; Ca2+ influx induces AMPK activation via CaMKK2; TAK1-mediated AMPK activation mechanism remains unclear. For compounds as AMPK activators, metformin/phenformin inhibits mitochondrial function and thus may affect ATP synthesis, which would mimic energy starvation; AICAR activates AMPK via forming ZMP in cells that acts as an analog of AMP; A769662 and salicylate induces allosteric activation requiring AMPK autophosphorylation (at serine 108, in pink) in the $\beta$ subunit.

1-D-ribofuranoside (AICAR) forms ZMP in cells as an analog of AMP and thus is capable of inducing AMPK activation with high popularity in AMPK studies. Through a different mechanism, i.e. by binding via the serine 108, an autophosphorylation site in the $\beta$ subunit, A769662 and salicylate allosterically activate AMPK. Furthermore, metformin and phenformin activate AMPK via inhibiting mitochondrial ATP synthesis, which mimics an energy-starvation status. (Figure 1)

AMPK in metabolism - Metabolism, categorized by catabolism and anabolism, is the chemical process that all cells in an organism perform to transform nutrients into fuel/ energy. As part of the normal human metabolic sustenance, foods are stored (anabolism) as either glycogen in liver and skeletal muscles or triglycerides in adipose tissue (12). During fasting or stress (catabolism), stored fuel would be used by the anti-insulin effects from catabolic hormones or factors (12). In regards to its pivotal role in energy balance regulation, signaling pathways in which AMPK is involved have been extensively studied under both conditions. In general, AMPK increases catabolic processes, such as glucose uptake/oxidation and fatty acid oxidation and inhibits anabolic outcomes, such as glycogen and lipid synthesis (13). Per example, AMPK regulates glucose transporter type 4 (GLUT4) trafficking in glucose uptake via phosphorylating TBC1 domain family member 1 and 4 (TBC1D1/4) (14). Similarly, glycogen synthase in glycogen synthesis and CD36 in fatty acid uptake are regulated by AMPK, although the exact mechanisms involved are less clear (13). In fatty acid synthesis and oxidation, acetyl CoA carboxylases (ACC1 and ACC2) are solidly accepted as AMPK downstream targets (15). Further, AMPK participates 
in lipase phosphorylation, such as hormone sensitive lipase (HSL) and adipocyte triglyceride lipase (ATGL) (16), and it is even playing a role in transcriptional control of metabolic enzymes. For example, sterol regulatory element binding protein 1c (SREBP) is found to be suppressed by AMPK which results in reduced lipogenesis and lipid accumulation (17). It has also been established that inflammatory conditions, usually coupled with metabolic disorders, is associated with reduction of AMPK activity; relevantly, AMPK acts as an inflammation suppressor via inhibition of NF-KB signaling (18).

AMPK in cell growth- Cell growth occurs in cell populations as part of cell cycle progression during gap phases 1 and 2 (G1, G2), in which nutrients and growth factors are necessary for energy supply and signal transduction. In this process, a conserved serine/threonine kinase mTOR (the mammalian target of rapamycin) plays crucial roles in regulating translation and cell division. Its kinase activity is also influenced by nutrient availability to determine whether cells undergo normal growing. As a metabolic checkpoint, AMPK suppresses mTORC1 (mTOR complex 1, both rapamycin- and nutrientsensitive (19)) activity via two pathways: 1) AMPK directly phosphorylates the tumor suppressor TSC2, a GTPase activating protein that, in conjunction with TSC1, negatively controls Rheb, a GTPase that activates mTORC1, and 2) AMPK phosphorylates Raptor (regulatory associated protein of mTORC1) which blocks mTORC1 phosphorylating substrates for signal transduction (20). Following nutrient starvation, AMPK also phosphorylates serine/threonine-protein kinase ULK1, which is required for autophagy (cellular amino acid 'recycling' mechanism) (21). Under stress conditions, e.g. glucose withdrawal, AMPK has also been reported to phosphorylate tumor suppressor protein P53 (22) and mediate a cells' "decision" on autophagy/apoptosis via phosphorylating cyclin-dependent kinase inhibitor 1B (p27) (23).

In summary, the (metabolic) stress-responsive AMPK holoenzyme is expressed in various isoform combinations in different cells and is regulated via different mechanisms, including cellular AMP level, $\mathrm{Ca}^{2+}$ influx and post-translational modifications. The complexity of AMPK regulation is reflected in its multiple functions in various cellular responses to nutrient environment, including metabolism and cell growth (Figure 2). Impaired AMPK activity is widely observed in metabolic disorders and inflammation; this makes AMPK an emerging druggable target for diabetes and other metabolic syndromes (24). The relevance of AMPK as a potential target in cancer (abnormal cell growth) remains under debate, due to its ambivalent involvement in cancer in both inhibition of anabolism for cancer cell proliferation and contribution in the plasticity of cancer cell for survival (25). Despite its recognized involvement in the regulation of a multitude of ATPdependent cellular processes, the exact mechanisms by which these processes are 


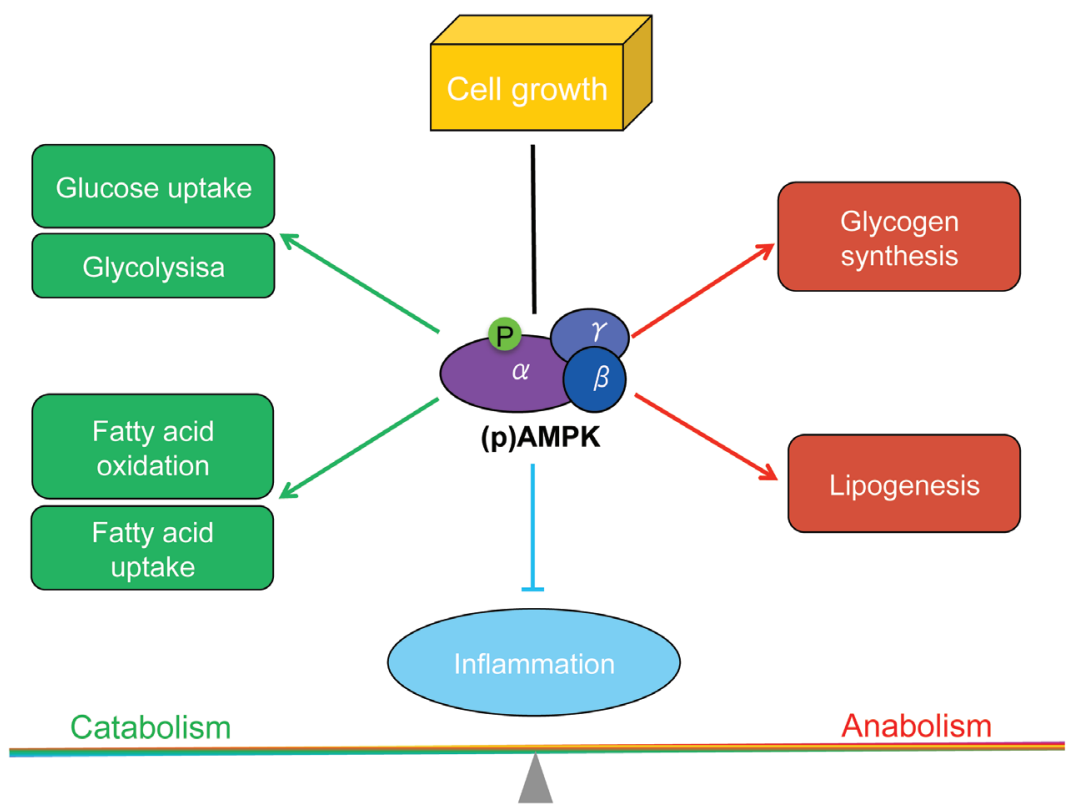

Figure 2. Cellular AMPK functions. The main role of AMPK in metabolism generally includes induction (in green) of catabolism (glucose uptake, glycolysis, fatty acid oxidation and fatty acid uptake) and inhibition (in red) of anabolism (glycogen synthesis and lipogenesis). AMPK works as a suppressor of inflammation. AMPK also regulates cell growth and cellular responses to microenvironment with various roles.

controlled by AMPK, and the identity of relevant AMPK targets and pathways are still largely obscure. Consequently, efforts aimed at AMPK-substrates identification are crucial for further elucidation of AMPK signaling networks and development of its full therapeutic potential.

\section{Novel AMPK target identification}

Various screening approaches have been developed for kinase-substrates identification with promising results, e.g. cDNA expression library (26), direct phosphorylation screenings of cell/tissue lysates $(27,28)$ or immunoprecipitation with specific antibody of AMPK substrate phosphorylation motif (29). Also, protein interaction studies were found to be effective in searching out putative substrates, e.g. coimmunoprecipitation coupled with mass spectrometry and yeast-two-hybrid technology $(30,31)$.

Among the methods to screen for kinase targets, the use of high-density human protein microarrays stands out, since it facilitates the identification of human kinasesubstrate proteins on a proteomic scale within a few working days (32-34). Preceding the studies reported herein, this method has been applied to screen AMPK substrates and a list of potential AMPK phosphorylation targets has been identified (35). MAP kinase- 


\begin{tabular}{|c|c|c|c|c|}
\hline & $\begin{array}{r}\text { NLS \& } \\
\text { elF4G } \\
\text { binding }\end{array}$ & $\begin{array}{c}\text { ATP } \\
\text { binding }\end{array}$ & $\begin{array}{c}\text { Activation } \\
\text { Loop(T209/214) }\end{array}$ & NES \\
\hline Mnk1a & & K & T T & \\
\hline Mnk1b & & K & $\mathbf{T} \mathbf{T}$ & \\
\hline
\end{tabular}

Figure 3. Structure of MNK1a and MNK1b. Schematic representation of MNK1 isoform difference. NLS, nuclear localization signal; NES, nuclear export signal.

interacting serine/threonine-protein kinase 1 (MNK1) has been identified as a potential AMPK target with highest score. The functional interaction of MNK1 and AMPK was extensively studied in this thesis.

\section{MNK1 regulation and function}

MNK1 structure and regulation-As one of the MAP kinase-interacting serine/threonineprotein kinases (MNKs), MNK1 was firstly identified in a substrate-screening report for extracellular-signal-regulated kinase 1 (ERK1) (26). Two isoforms encoded by the MNKN1 gene, MNK1a and MNK1b (Figure 3), were identified later with distinct C-terminal domain structure: MNK1a contains unique 89 amino acid C-terminus, harboring an nuclear export sequence (NES) and a MAPK-binding domain, while the C-terminus of MNK1b consists of distinct 12 amino acids (36). Functionally, MNK1a is tightly regulated by ERK and P38 in cellular responses to both growth factors and stress (37), while MNK1b shows higher basal kinase activity $(36,38)$. Phosphorylation of Thr209 and Thr214 in the activation T-loop of MNK1a and MNK1b is necessary for kinase activation (39). Furthermore, MNK1a has been shown to undergo conformational changes upon T-loop phosphorylation and an $\alpha$-helical domain in its $\mathrm{C}$-terminus was suggested to regulate the kinase activity, probably via influencing the access of MAPKs to the kinase domain (40).

\section{MNK1 function}

elF4E in protein translation-The best characterized substrate of MNK1 is the eukaryotic translation initiation factor 4E (elF4E) (41), which directs ribosomes to the cap-structure of mRNA. In this process, elF4G is thought to recruit both activated MNK1 and elF4E in order to facilitate MNK1-mediated elF4E Ser209 phosphorylation (42). Although the exact functional relevance of elF4E phosphorylation in protein translation still remains undetermined (43), aberrant expression of eIF4E has been associated with promotion of tumorigenesis and tumor progression $(44,45)$. Interestingly, expression of MNKs (MNK1 and MNK2) and phosphorylation of elF4E have been found to be dispensable for normal cell growth (46). Furthermore MNKs have been implicated in drug resistance development in the context of different cancer types (47-49). Because of these observations, MNKs are currently considered as potential cancer therapy targets (50).

hnRNP A1 \& PSF in TNF-a production-The mRNA translation of the pro-inflammatory 


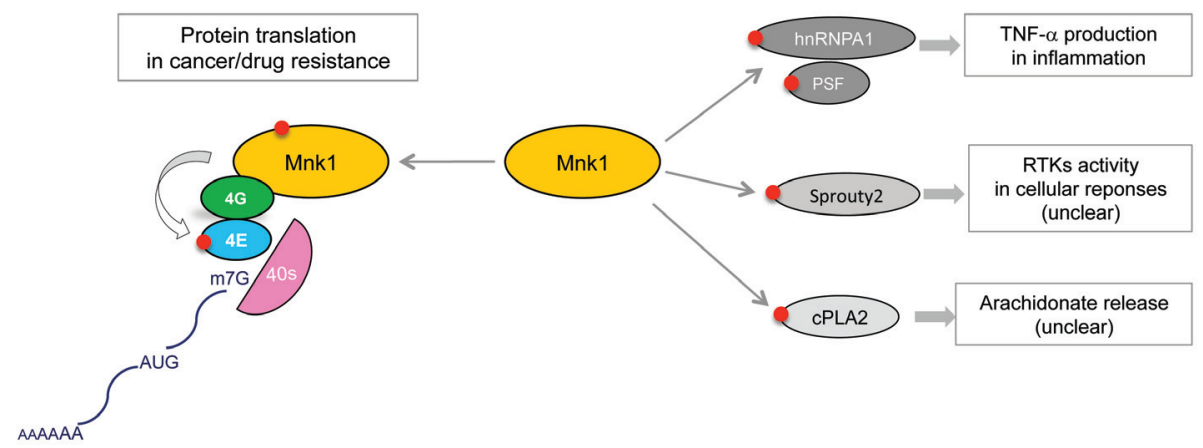

Figure 4. MNK1 cellular functions. The best-studied function of MNK1 is its phosphorylation of elF4E via elF4G binding. elF4E recognizes cap-structure of $\mathrm{mRNA}$ and directs ribosomes for translation scanning. MNK1-elF4E is currently associated with cancer therapy and drug resistance researches. MNK1-mediated phosphorylation of hnRNPA1 and PSF regulates pro-inflammatory TNF- $\alpha$ mRNA translation via its AU rich elements (AREs). MNK1 stablizes Sprouty2 for mediation of RTKs activity. MNK1 also phosphorylates CPLA2 for arachidonate release. elF4, eukaryotic translation initiation factor 4; 40s, ribosome; hnRNPA1, Heterogenous nuclear ribonucleoprotein A1; PSF, the PTB (polypyrimidine tract- binding protein)-associated splicing factor; TNF- $\alpha$, tumor necrosis factor- $\alpha$; RTKs, receptor tyrosine kinases; cPLA2, cytosolic phospholipase A2.

cytokine TNF-a is tightly regulated by the AU rich elements (AREs) in the 3'UTR. As a TNF-a ARE binding protein, hnRNP A1 is directly phosphorylated by MNKs which leads to its dissociation from AREs and enhancement of TNF-a production (51). Similarly, PSF [the PTB (polypyrimidine tract- binding protein)-associated splicing factor] is also both a TNF-a AREs binding partner and a phosphorylation target for MNKs, however, the effect of MNKs-PSF on TNF-a translation still remains unclear (52).

Other targets-MNK1 has been reported to increase the stability of Sprouty2, which acts as a negative mediator of receptor tyrosine kinases (RTKs) activity $(53,54)$. It was also shown that type I interferon (IFN), a cytokine with anti-proliferative and anti-viral activity, induces up-regulation of Sprouty proteins in a MNK kinase-dependent manner (55). Although MNK-Sprouty signaling is believed to be implicated in a wide variety of cellular responses, their exact biological relevance awaits further elucidation. Another potential target of MNK1 is cytosolic phospholipase A2 (cPLA2). MNK1 is found to phosphorylate cPLA2 directly and thereby regulate arachidonate release, which acts as an important messenger precursor in inflammation, immunity and in the central nervous system $(56,57)$. Nevertheless, the exact role of MNK1 and the connections to potential MNK1 substrates has remained scarce.

In summary, MNK1 mediates cellular signaling pathways in response to both growth factors and stress (Figure 4). MNK1 is mainly known for its involvement in cap-dependent/independent protein translation and inflammation. Inhibitors of MNK are considered as a possible anti-cancer strategy. 


\section{Aims of the thesis}

With the intention of identifying more AMPK targets, the lab previously carried out a protein microarray screen that yielded a list of potential candidate substrates (35). MNK1 stood out with highest scores, i.e. strongly phosphorylated by active AMPK. Based on the novelty of the AMPK-MNK1 connection and possible roles in protein translation and thus in multifactorial human conditions like metabolic syndrome and cancer, the project was initiated in order to first examine their functional relation at the molecular level. Chapter $\mathbf{2}$ summarizes a number of in vitro methods used to study AMPK. Chapter $\mathbf{3}$ outlines a series of experiments aimed at validation of MNK1 as a novel AMPK target in both cellfree and mammalian cell systems. In this chapter, MNK1a serine 353 (S353) was identified and validated as specific AMPK phosphorylation site. Furthermore, mutation of S353 to a phosphorylation mimicking state (S353D) was observed to result in higher kinase activity toward elF4E phosphorylation. In Chapter 4, the effect of AMPK-dependent MNK1a phosphorylation is further tested in the context of the regulation of protein translation as well as cell growth control. In addition, the tripartite regulatory interaction between AMPK, MNK and ERK is explored at a molecular level. Following up on the properties of other MAPKAPK family members, Chapter $\mathbf{5}$ focuses on investigating possible roles of the AMPK-MNK1 axis in regulating gene transcription. As general discussion, Chapter 6 shortly reviews selected critical aspects and offers perspectives for further research. 


\section{References}

1. Galgani, J., and Ravussin, E. (2008) Int J Obes (Lond) 32 Suppl 7, S109-119

2. Viollet, B., Horman, S., Leclerc, J., Lantier, L., Foretz, M., Billaud, M., Giri, S., and Andreelli, F. (2010) Crit Rev Biochem Mol Biol 45, 276-295

3. Steinberg, G. R., and Kemp, B. E. (2009) Physiol Rev 89, 1025-1078

4. Salt, I., Celler, J. W., Hawley, S. A., Prescott, A., Woods, A., Carling, D., and Hardie, D. G. (1998) Biochem J 334 ( Pt 1), 177-187

5. Woods, A., Vertommen, D., Neumann, D., Turk, R., Bayliss, J., Schlattner, U., Wallimann, T., Carling, D., and Rider, M. H. (2003) J Biol Chem 278, 28434-28442

6. Fogarty, S., and Hardie, D. G. (2010) Biochim Biophys Acta 1804, 581-591

7. Shackelford, D. B., and Shaw, R. J. (2009) Nat Rev Cancer 9, 563-575

8. Woods, A., Dickerson, K., Heath, R., Hong, S. P., Momcilovic, M., Johnstone, S. R., Carlson, M., and Carling, D. (2005) Cell Metab 2, 21-33

9. Herrero-Martin, G., Hoyer-Hansen, M., GarciaGarcia, C., Fumarola, C., Farkas, T., Lopez-Rivas, A., and Jaattela, M. (2009) Embo J 28, 677-685

10. Xiao, B., Heath, R., Saiu, P., Leiper, F. C., Leone, P., Jing, C., Walker, P. A., Haire, L., Eccleston, J. F., Davis, C. T., Martin, S. R., Carling, D., and Gamblin, S. J. (2007) Nature 449, 496-500

11. Suter, M., Riek, U., Tuerk, R., Schlattner, U., Wallimann, T., and Neumann, D. (2006) J Biol Chem 281, 32207-32216

12. Tsatsoulis, A., Mantzaris, M. D., Bellou, S., and Andrikoula, M. (2013) Metabolism 62, 622-633

13. Hardie, D. G., Ross, F. A., and Hawley, S. A. (2012) Nat Rev Mol Cell Biol 13, 251-262

14. Sakamoto, K., and Holman, G. D. (2008) Am J Physiol Endocrinol Metab 295, E29-37

15. Carling, D., Zammit, V. A., and Hardie, D. G. (1987) FEBS Lett 223, 217-222

16. Mihaylova, M. M., and Shaw, R. J. (2013) Trends Endocrinol Metab 24, 48-57

17. Li, Y., Xu, S., Mihaylova, M. M., Zheng, B., Hou, X., Jiang, B., Park, O., Luo, Z., Lefai, E., Shyy, J. Y., Gao, B., Wierzbicki, M., Verbeuren, T. J., Shaw, R. J., Cohen, R. A., and Zang, M. (2011) Cell Metab 13, 376-388

18. Salminen, A., Hyttinen, J. M., and Kaarniranta, K. (2011) J Mol Med (Berl) 89, 667-676

19. Guertin, D. A., and Sabatini, D. M. (2007) Cancer Cell 12, 9-22

20. Mihaylova, M. M., and Shaw, R. J. (2011) Nat Cell Biol 13, 1016-1023

21. Egan, D. F., Shackelford, D. B., Mihaylova, M. M., Gelino, S., Kohnz, R. A., Mair, W., Vasquez, D. S.,
Joshi, A., Gwinn, D. M., Taylor, R., Asara, J. M., Fitzpatrick, J., Dillin, A., Viollet, B., Kundu, M., Hansen, M., and Shaw, R. J. (2011) Science 331, 456-461

22. Jones, R. G., Plas, D. R., Kubek, S., Buzzai, M., $\mathrm{Mu}$, J., Xu, Y., Birnbaum, M. J., and Thompson, C. B. (2005) Mol Cell 18, 283-293

23. Liang, J., Shao, S. H., Xu, Z. X., Hennessy, B., Ding, Z., Larrea, M., Kondo, S., Dumont, D. J., Gutterman, J. U., Walker, C. L., Slingerland, J. M., and Mills, G. B. (2007) Nat Cell Biol 9, 218224

24. Zhang, B. B., Zhou, G., and Li, C. (2009) Cell Metab 9, 407-416

25. Zadra, G., Batista, J. L., and Loda, M. (2015) Mol Cancer Res 13, 1059-1072

26. Fukunaga, R., and Hunter, T. (1997) Embo J 16, 1921-1933

27. Knebel, A., Morrice, N., and Cohen, P. (2001) Embo J 20, 4360-4369

28. Tuerk, R. D., Thali, R. F., Auchli, Y., Rechsteiner, H., Brunisholz, R. A., Schlattner, U., Wallimann, T., and Neumann, D. (2007) J Proteome Res 6, 3266-3277

29. Kane, S., Sano, H., Liu, S. C., Asara, J. M., Lane, W. S., Garner, C. C., and Lienhard, G. E. (2002) J Biol Chem 277, 22115-22118

30. Archambault, V., Chang, E. J., Drapkin, B. J., Cross, F. R., Chait, B. T., and Rout, M. P. (2004) Mol Cell 14, 699-711

31. Causier, B. (2004) Mass Spectrom Rev 23, 350367

32. MacBeath, G., and Schreiber, S. L. (2000) Science 289, 1760-1763

33. Schnack, C., Hengerer, B., and Gillardon, F. (2008) Proteomics 8, 1980-1986

34. Mok, J., Im, H., and Snyder, M. (2009) Nat Protoc 4, 1820-1827

35. Thali, R. F. (2010) Exploring the Target Spectrum of AMP-activated protein kinase, ETH Zürich, Zürich, Switzerland

36. O'Loghlen, A., Gonzalez, V. M., Pineiro, D., Perez-Morgado, M. I., Salinas, M., and Martin, M. E. (2004) Exp Cell Res 299, 343-355

37. Waskiewicz, A. J., Flynn, A., Proud, C. G., and Cooper, J. A. (1997) Embo J 16, 1909-1920

38. O'Loghlen, A., Gonzalez, V. M., Jurado, T., Salinas, M., and Martin, M. E. (2007) Biochim Biophys Acta 1773, 1416-1427

39. Chrestensen, C. A., Shuman, J. K., Eschenroeder, A., Worthington, M., Gram, H., and Sturgill, T. W. (2007) J Biol Chem 282, 4243-4252

40. Goto, S., Yao, Z., and Proud, C. G. (2009) Biochem J 423, 279-290 
41. Wang, X., Flynn, A., Waskiewicz, A. J., Webb, B. L., Vries, R. G., Baines, I. A., Cooper, J. A., and Proud, C. G. (1998) J Biol Chem 273, 9373-9377

42. Shveygert, M., Kaiser, C., Bradrick, S. S., and Gromeier, M. (2010) Mol Cell Biol 30, 51605167

43. Joshi, S., and Platanias, L. C. (2014) World journal of biological chemistry 5, 321-333

44. Furic, L., Rong, L., Larsson, O., Koumakpayi, I. H., Yoshida, K., Brueschke, A., Petroulakis, E., Robichaud, N., Pollak, M., Gaboury, L. A., Pandolfi, P. P., Saad, F., and Sonenberg, N. (2010) Proceedings of the National Academy of Sciences of the United States of America 107, 14134-14139

45. Proud, C. G. (2015) Biochim Biophys Acta 1849, 766-773

46. Ueda, T., Watanabe-Fukunaga, R., Fukuyama, H., Nagata, S., and Fukunaga, R. (2004) Mol Cell Biol 24, 6539-6549

47. Zhang, M., Fu, W., Prabhu, S., Moore, J. C., Ko, J., Kim, J. W., Druker, B. J., Trapp, V., Fruehauf, J., Gram, H., Fan, H. Y., and Ong, S. T. (2008) Mol Cell Biol 28, 6496-6509

48. Astanehe, A., Finkbeiner, M. R., Krzywinski, M., Fotovati, A., Dhillon, J., Berquin, I. M., Mills, G. B., Marra, M. A., and Dunn, S. E. (2012) Oncogene 31, 4434-4446

49. Kern, S. E., Shi, C., and Hruban, R. H. (2011) J Pathol 223, 295-306
50. Hou, J., Lam, F., Proud, C., and Wang, S. (2012) Oncotarget 3, 118-131

51. Buxade, M., Parra, J. L., Rousseau, S., Shpiro, N., Marquez, R., Morrice, N., Bain, J., Espel, E., and Proud, C. G. (2005) Immunity 23, 177-189

52. Buxade, M., Morrice, N., Krebs, D. L., and Proud, C. G. (2008) J Biol Chem 283, 57-65

53. Yigzaw, Y., Cartin, L., Pierre, S., Scholich, K., and Patel, T. B. (2001) J Biol Chem 276, 22742-22747

54. Yusoff, P., Lao, D. H., Ong, S. H., Wong, E. S., Lim, J., Lo, T. L., Leong, H. F., Fong, C. W., and Guy, G. R. (2002) J Biol Chem 277, 3195-3201

55. Sharma, B., Joshi, S., Sassano, A., Majchrzak, B., Kaur, S., Aggarwal, P., Nabet, B., Bulic, M., Stein, B. L., McMahon, B., Baker, D. P., Fukunaga, R., Altman, J. K., Licht, J. D., Fish, E. N., and Platanias, L. C. (2012) J Biol Chem 287, 42352 42360

56. Hefner, Y., Borsch-Haubold, A. G., Murakami, M., Wilde, J. I., Pasquet, S., Schieltz, D., Ghomashchi, F., Yates, J. R., 3rd, Armstrong, C. G., Paterson, A., Cohen, P., Fukunaga, R., Hunter, T., Kudo, I., Watson, S. P., and Gelb, M. H. (2000) J Biol Chem 275, 37542-37551

57. Funk, C. D. (2001) Science 94, 1871-1875 

2.

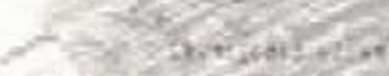

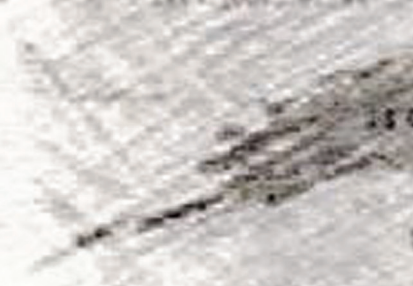

$7{ }^{2}$

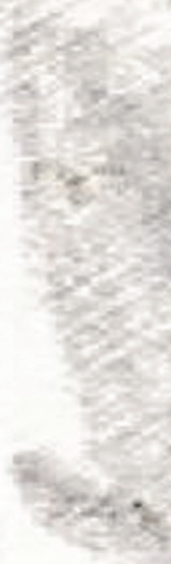

N5
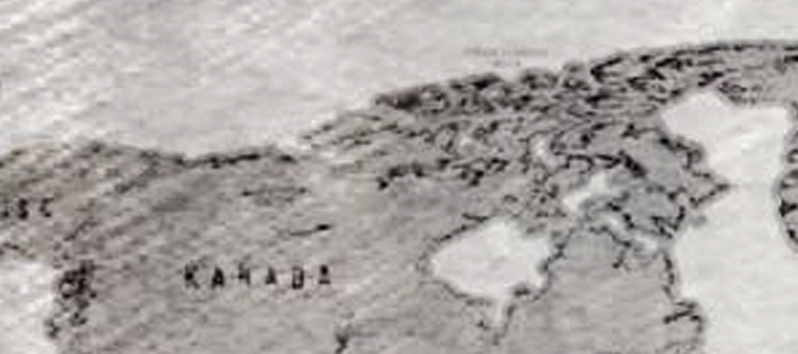

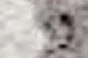

CA+Ca:
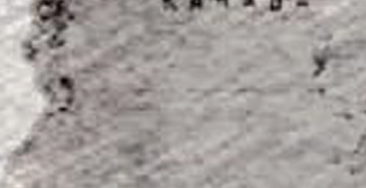

$7=0 \leq-y \leq A$

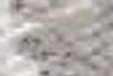
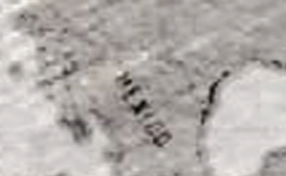

$\cdots$ 


\section{In vitro methods to study AMPK}

Xiaoqing Zhu, J. Willem Voncken, Dietbert Neumann*

*corresponding author: d.neumann@maastrichtuniversity.nl Department of Molecular Genetics, CARIM School for Cardiovascular Diseases,

Maastricht University Medical Centre, P.O. Box 616, 6200 MD Maastricht, The Netherlands 


\begin{abstract}
AMPK studies in cell-free and cellular systems have significantly contributed to recent progress in the AMPK field. Biochemical characterization, structure determination and elucidation of AMPK-dependent signaling events benefit from application of state-of-the-art tools and methodology. This chapter provides a synopsis of recombinant protein expression systems, biochemical and cell-based study methods. We summarize three different expression systems for AMPK production: bacteria, insect cells and mammalian cells. In addition, kinase activity measurement, kinase substrate identification and determination of physical interaction with AMPK are discussed. The last part of this chapter focuses on the use of pharmacological activation, inhibition and molecular genetic tools to study AMPK involvement in cellular signaling pathways.
\end{abstract}




\section{Expression/Production of AMPK protein}

To biochemically characterize AMPK and to study its involvement in cellular processes, AMPK protein expression is an essential step. For any expressed protein, quality and quantity are two crucial factors for further successful application in vitro or in vivo. Since cellular AMPK functions as a heterotrimeric protein complex comprising $\alpha, \beta$ and $\gamma$ subunits, the formation of AMPK requires co-expression of all three subunits. To date, a number of expression systems are used in the AMPK field, including prokaryotic systems, insect virus-based and mammalian systems. These systems and their applications are discussed in the sections below.

\section{Prokaryotic expression systems}

As the easiest and most widely used method for recombinant protein production, the bacterial expression system combines several potential advantages, such as a rapid result, high yield, including the possibility of upscaling and absence of posttranslational modifications (PTMs).

Production of AMPK heterotrimeric complexes has been a challenging task, due to low protein solubility and failure of co-renaturation from separately purified denatured single subunits. A polycistronic bacterial expression system has been developed to overcome these problems (1). Expression of all three subunits from a single tricistronic vector in bacteria conveniently produces the functional heterotrimer. AMPK complexes can thus be obtained in the milligram range from Escherichia coli. This method was also shown to be valuable for production of uniform subunit isoform composition and was applied in the majority of biochemical and structural studies. However, the tricistronic expression strategy is not equally powerful for all subunit isoform combinations. For example, the human muscle-specific AMPK isoform combination $\alpha 2 \beta 2 \gamma 3$ was successfully expressed and purified from a single tricistronic transcript in E. coli, which offered insight into the function of this AMPK (2), but expression levels of this isoform complex were too low to enable structural studies using e.g. X-ray crystallography.

Notably, an activating phosphorylation event is often required in the case of recombinant protein kinases. Indeed AMPK heterotrimers purified from the above described tricistronic vectors are almost entirely inactive due to the absence of upstream activating kinases in bacteria. In order to activate AMPK, upstream kinases (e.g. LKB1 complex or CaMKK2) have thus been added to purified bacterially expressed AMPK complexes in the presence of ATP. CaMKK2 can be easily produced in bacteria, which makes this kinase suitable for applications where an activating AMPK $\alpha$ threonine 172 (T172) phosphorylation event is part of the assay (3). It has also been reported that activated AMPK could be re-purified after in vitro activation by either recombinant CaMKK2 or LKB1 


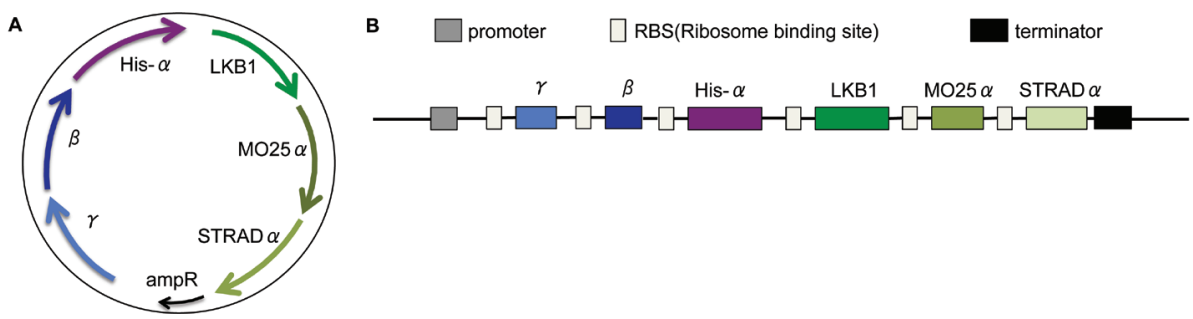

Figure 1. Bacterial expression construct for production of active AMPK complexes. (A) Schematic representation of the hexacistronic expression vector encoding for the AMPK heterotrimer and LKB1 complex for expression of active AMPK in bacteria. (B) The hexacistronic gene construct consists of a single promoter, open reading frames of AMPK $\gamma$ subunit, $\beta$ subunit, hexahistidine-tagged $\alpha$ subunit, LKB1, MO25a and STRADa, respectively, interspersed with ribosome binding sites (RBS), and a transcriptional terminator sequence. Plasmid maps are not drawn to scale. This vector and its application were described recently $(6,7)$.

complex (4). Functional LKB1 complex (consisting of LKB1, MO25 $\alpha$ and STRAD $\alpha$ ) can also be produced in bacteria, although purification yield was low (5). In cases where bacterial production of active AMPK is desirable, LKB1 complex can be co-expressed with AMPK. For this purpose a single hexacistronic expression vector encoding three AMPK and three LKB1 subunits was employed (Figure 1A\&B). This strategy directly yields active AMPK, as reported recently $(6,7)$.

Tricistronic constructs for expression of AMPK usually encode a hexahistidine (His)tagged $\alpha$-subunit and non-tagged $\beta$ and $\gamma$-subunits (although this might not be exclusive). Thus, commonly, His-tagged AMPK protein obtained from a prokaryotic expression system can be purified by Nickel affinity chromatography in a single-step using standard procedures (Figure 2). To exclude possible problems from the presence of His-tag for biochemical characterization of AMPK, especially crystallization, non-tagged mammalian AMPK isoform combinations were purified successfully from bacteria using a multi-step chromatography approach that included anion exchange chromatography and size-exclusion chromatography (8). Automation of such multi-dimensional purification protocol was established even allowing for full Internet remote control (9).

To date, the bacterial expression system has been validated as a useful source of various AMPK isoforms as either active or inactive enzyme. Moreover, the bacterial system has been utilized for expression of functional mutants, such as kinase-defective mutants (e.g. $\alpha 1 \mathrm{D} 157 \mathrm{~A} \beta 1 \gamma 1$ ) or truncation mutants (e.g. lacking the kinase domain in the $\alpha$-subunit).

\section{Baculovirus-insect cell expression systems}

Baculovirus-mediated protein expression can provide both high protein yield and eukaryotic protein PTMs (10). Infected insect cells co-expressing all three AMPK subunits from three individual baculoviral vectors provided stable heterotrimeric complex, 


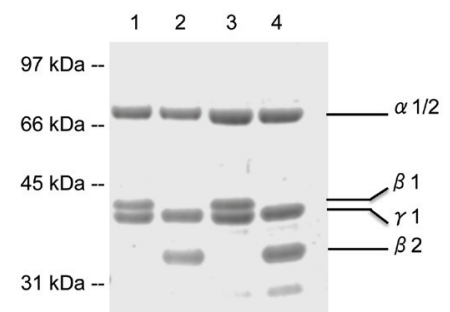

Figure 2. Bacterially expressed purified AMPK isoforms. Tricistronic plasmids encoding various AMPK isoforms were transformed to competent $E$. coli and harvested after overnight expression in auto-inducing media. Proteins were purified by Nickel-affinity chromatography and purity was analysed by SDS-PAGE followed by Coomassie Brilliant Blue staining. His- $\alpha 1 \beta 1 \gamma 1$ (Lane 1), His- $\alpha 1 \beta 2 \gamma 1$ (Lane 2), His- $\alpha 2 \beta 1 \gamma 1$ (Lane 3), His- $\alpha 2 \beta 2 \gamma 1$ (Lane 4).

whereas separate expression/purification resulted in protein insolubility (11). Successful AMPK $\alpha 1 \beta 1 \gamma 1$ complex expression was achieved (12). However, also co-expression of only the $\gamma 1$ and the $C$-terminus of $\beta 1$ subunit resulted in a stable complex in the absence of the $\alpha$ subunit in insect cells (12).

The main advantage of insect cell expression is the presence of eukaryotic PTMs, which is for example highlighted by the identification of a gatekeeper function for $\mathrm{N}$-terminal myristoylation of the $\beta$-subunit (13). Furthermore, by using recombinant human AMPK produced in insect cell systems, several additional phosphorylation sites have been identified (14). Similar to the bacterially expressed protein insect cell-based systems produce relatively high protein yields and for protein purification purposes affinity chromatography and anion exchange chromatography were applied yielding high purity (12). Compared to the bacterial expression system, AMPK expression in insect cells offers the potential advantage that relevant eukaryotic PTMs are present on the artificially expressed AMPK protein.

\section{Mammalian tissues and expression systems}

Mammalian tissues and cells are sources for endogenous AMPK complex proteins. In addition, mammalian cell cultures have been used for recombinant protein expression. The expression of mammalian proteins in mammalian cells generally results in correct folding, assembly of the required protein complex components and post-translational processing, which are all important for faithful biological activity.

In the early days of research into AMPK function, native AMPK was extracted from tissues and enriched in a series of subsequent purification steps, e.g., a combination of DEAE-sepharose, Blue-sepharose and size exclusion chromatography was applied to purify AMPK from male Wistar rat livers (15). Later, a number of bio-affinity based purification methods have been developed to increase the efficiency of AMPK isolation, 
for example a specific ATP- $\gamma$-Sepharose resin (16) and an a1 isoform-specific peptide substrate affinity-chromatography column with ADR1 (222-234)P229 (LKKLTRRPSFSAQ) (17).

For expression of exogenous recombinant protein, different vectors are available to transfer the target genes into host cells. These vectors range from non-selectable vectors to vectors carrying selection markers (usually eukaryotic antibiotic resistance markers) and include non-viral as well as viral (adeno-, retro-, lentiviral) vectors. Widely used and relatively easily transfectable mammalian cell lines include Human embryonic kidney (HEK 293) and Chinese hamster ovary (CHO) cells.

Although mammalian expression systems produce proteins harbouring native features (PTMs, folding, interaction), their main application has been in the exploration of cellular signaling pathways and interaction networks. Hence, over-expression of exogenous AMPK in mammalian cells is a widely applied method. To this end, mammalian expression constructs are transfected or virally transduced to a cell type of choice. As an example, both the constitutively active and dominant-negative forms of AMPK $\alpha$ have been used to define the role of AMPK in glucose uptake regulation by metformin in skeletal muscle cells (18). Notably, although single subunit overexpression is achievable and produces interpretable results, triple transfection ( $\alpha, \beta, \gamma$ subunits co-expression) was shown to increase AMPK kinase activity up to 50-110 fold compared with single subunit expression in mammalian cells (19). Therefore, co-expression of all three AMPKcomplex subunits is highly recommended and widely applied in cellular signaling studies. For instance, co-expression of AMPK $\alpha 1, \beta 1$ and $\gamma 1$ has contributed to the elucidation of the mechanism underlying AMPK activation by A-769662 and AMP (20) and the identification of an autophosphorylation event that regulates AMPK-glycogen binding affinity (7).

For both endogenous and exogenous protein purification, highly specific and highaffinity reagents, such as (PTM-) specific antisera, have been useful to target and immune-capture proteins of interest from cell extracts $(21,22)$. At present, most researchers choose to enrich endogenous AMPK protein by immunoprecipitation from mammalian cells using specific antibodies, e.g, by immunoprecipitating AMPK from cell lysate with a highly selective anti-a1/2 antibodies raised in sheep and protein $\mathrm{G}$ sepharose (23).

\section{Biochemical characterization of AMPK}

Structural and functional analysis of AMPK requires AMPK-specific knowledge and the availability of apt biochemical tools. Vice versa, structural data fertilized the biochemical characterization of AMPK. Thus, the interplay between structural biology 
and biochemistry has provided significant novel insights into the molecular functioning of AMPK.

\section{AMPK kinase activity measurement}

In essence protein kinases are phosphoryl transferases that transfer the $\gamma$-phosphate group of ATP to a threonine, serine or tyrosine residue on specific protein substrates. Therefore, protein kinase activity measurement is the determination of phosphate transfer, i.e. by quantifying the production of the phosphorylated products or by detecting the ADP production, which also should inversely mirror the decrease of ATP (24).

Among various assays for AMPK activity measurement, the radiometric assay is a common method, although the introduction of non-radioactive assay formats has reduced the frequency of its application. In any such assay, AMPK is incubated with a synthetic substrate peptide, in the presence of radiolabeled ( ${ }^{32} \mathrm{P}-\gamma$-ATP or ${ }^{33} \mathrm{P}-\gamma$-ATP) or non-labeled ATP. Incorporation of the radiolabel to the substrate peptide can be quantified by determining scintillation counts after spotting the reaction mix onto a phosphocellulose paper, i.e. the 'classical' kinase assay that has been successfully implemented for numerous kinases. A more rough estimation of kinase activity may alternatively be obtained by using a protein substrate and comparing autoradiography signals after separating the reaction mix by gel electrophoresis. If using nonradiolabeled ATP various commercial kits are available for quantification, such as luminometer-based, fluorescent and colorimetric assays.

Different substrate peptides of AMPK have been reported. The synthetic SAMS peptide (HMRSAMSGLHLVKRR) was shown to be a specific target for AMPK from rat liver (25). Similarly, AMARA peptide (AMARAASAAALARRR) has been used to measure AMPK activity in cell lysates (26). However, the vast majority of researchers utilized SAMS peptide in their AMPK studies, e.g., it was shown that LKB1 directly phosphorylates and activates AMPK kinase activity toward SAMS peptide (27). To determine AMPK activity, various additional technologies and platforms have been developed and are available from commercial suppliers that are based on the recognition of the phosphorylated substrate peptide by suitable phosphorylation-specific antibodies. Alternative methods include the design of fluorescent fusion proteins, which upon phosphorylation induce a change of Förster resonance energy transfer (FRET) as further detailed in Book Chapter 22.

All of the above kinase activity measurements offer their specific advantages, but focus on either substrate phosphorylation or on ATP consumption as a read-out. Analysis of the kinase activity reaction mixture by high performance liquid chromatography 
(HPLC) has been developed as an alternative (4). HPLC-based analysis allows for quantification of all nucleotides (ATP, ADP and AMP), plus it provides an accurate determination of SAMS and phosphorylated SAMS (pSAMS) peptide; the latter requires a separate HPLC run using a different column chemistry, solutes and eluent. In contrast with other methods, the HPLC-based read-out enables monitoring of AMP levels, which may be present as contamination or produced during the assay in the reaction mixture. It is also possible to record dynamic changes of ATP/ADP and pSAMS/SAMS as a function of time (i.e. by taking samples of an activity assay at different time points). Moreover, this single assay-based technology provides important data cross-validation, since a perfect correlation between ADP formation and pSAMS detection within the duration of the AMPK assay was observed (4).

\section{AMPK structure determination}

The detailed atomic structure of AMPK has mainly been captured by X-ray crystallography. Thus, AMPK was purified in large quantities and subjected to crystallization trials. The mammalian AMPK structure and AMP-binding sites were elucidated recently (28). Also, the binding of small molecule activators, such as A769662, was elucidated by X-ray crystallography (29). These studies crucially rely on the ability to produce AMPK complex in sufficient amount, purity and homogeneity. Accordingly, the bacterial polycistronic expression strategy (section 1.1, this chapter) has been used in virtually all AMPK structural studies published to date.

Nuclear magnetic resonance (NMR) spectroscopy is alternative method to obtain structural insight, which has been applied to isolated AMPK domains and even revealed dynamic changes or affinities. As an example, the carbohydrate-binding module of muscle-specific AMPK $\beta 2$ subunit has been found to display higher affinity for carbohydrates than the corresponding domain of the AMPK $\beta 1$ subunit (30). NMR-based analyses have also demonstrated that the isolated CBM domain alone shows weak interaction with A769662 (31).

\section{Screening methods for AMPK downstream target identification}

A multidimensional substrate-screen for protein kinases (MudSeeK) in tissue homogenates has been recently developed to identify downstream targets for AMPK (32). This proteomic method utilises radiolabeling of substrate proteins by activated AMPK in presence of radiolabeled ATP. Phosphorylated substrates are detected after separation of proteins by two-dimensional gel electrophoresis and subsequent autoradiography. Although the principle is simple, several steps are necessary and crucial for success (not further detailed herein). In this study and subsequent work (33), the MudSeeK approach has proven effective for AMPK substrate protein identification with 


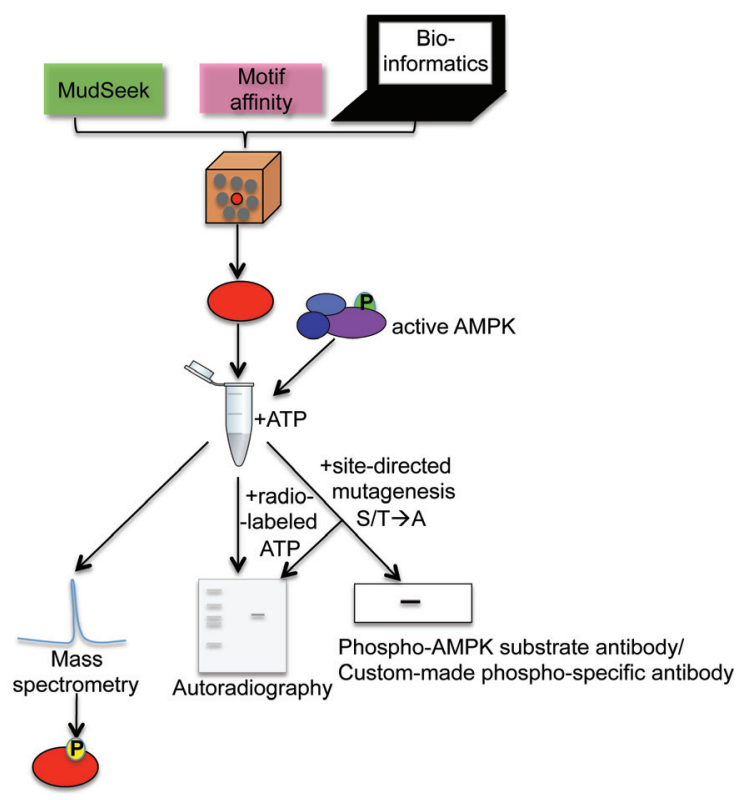

Figure 3. Workflow of AMPK downstream target identification. Potential AMPK targets are identified via MudSeek or motif affinity screening. In silico prediction software yields potential AMPK substrates harbouring potential phosphorylation sites. Validation of a candidate target protein as AMPK substrate can be performed in kinase assays using active AMPK, radiolabeled ATP and autoradiography. Similar reaction mixtures can also be used for mass spectrometric analysis for phosphorylation site identification. Site-directed mutagenesis can then be employed by exchanging the putative serine/ threonine target-residues of candidate substrate proteins into alanine (non-phosphorylatable) to validate whether these amino acids are AMPK targets in vitro and in vivo (using phospho-AMPK substrate antibody/custom-made phosphorylation-specific antibody), and to study the biological relevance of phosphorylation at these sites.

a low number of false-positive hits.

A bioinformatics based approach has been applied to search for the established AMPK substrate motif. Such method predicts potentially novel AMPK substrates and their AMPK-targeted phosphorylation sites. As an example, Serine 722 and 792 of the regulatory-associated protein of mechanistic target of rapamycin (Raptor) have been predicted as AMPK target sites by Scansite (http://mit.scansite.edu) and Prosite (http:// ca.expasy.org/prosite/) (34). Moreover, a substrate-specific antibody was developed based on the known consensus of AMPK phosphorylation motif (LXRXXpS/pT). Using this antibody, 57 proteins recently were identified as potential AMPK targets (35).

Following-up on the results of the screening methods above, each putative AMPK substrate protein requires rigorous validation as AMPK target. As a first step, this can be verified in in-vitro kinase assay (IVK) with active AMPK using radiolabeled ATP and autoradiography. For phosphorylation site identification a similar reaction mix may be subjected to mass spectrometry analysis, most often involving SDS electrophoresis and 
isolation of tryptic peptides from gel pieces. Site-directed mutagenesis in combination with IVK is frequently used to validate a newly identified phosphorylation site. To this end, the presumed serine or threonine residue of the AMPK target site is exchanged to alanine and the target protein is produced in a recombinant expression system. Upon incubation of wild type or the mutant with active AMPK, phosphorylation of the target protein can be detected by either autoradiography or antibodies (phospho-AMPK substrate antibody/custom-made phosphorylation-specific antibody). The workflow of AMPK downstream target identification is depicted in Figure 3.

Recently, a chemical genetics approach was developed to identify AMPK targets (36). In this method, AMPK $\alpha 2$ subunit was genetically engineered to use $\mathrm{N}^{6}$-modified ATPYS analogs for substrate thiophosphorylation. Next, the transferred thiophosphate on serine or threonine residues was chemically alkylated. This alkylation can be recognized by a thiophosphate ester-specific antibody that is used to enrich AMPK target proteins by immuno-affinity capturing for subsequent identification by mass spectrometry.

\section{Physical interaction studies}

Physical interaction studies are performed to explore binding affinity of nucleotides, drugs or interaction partners with AMPK. Among these studies, Surface Plasmon Resonance (SPR) is a widely used method, which is versatile and label-free and has outstanding sensitivity. The technology uses purified AMPK protein that is captured on a sensor chip. Binding of drugs or nucleotides causes a detectable real-time angle shift of light reflected from the chip surface. Variation in binding response value makes the SPR technology useful to detect differences in binding affinity (29). For example, glutathione S-transferases (GST) were identified as AMPK binding partners by using this method (37). Similarly, another optical technique called Bio-layer interferometry (BLI) uncovers AMPK binding with small molecules in real-time by measuring a wavelength shift in the interference pattern (31,38). Nuclear magnetic resonance (NMR) spectroscopy, as previously discussed in the context of atomic structure resolution, can also be applied for this purpose. Extensive studies were performed using the yeast two-hybrid screening approach leading to the identification of multiple novel protein binding partners of AMPK subunits, i.e. with preference for the AMPK $\beta$-subunit (39).

\section{Methods to study AMPK in cellular signaling pathways}

AMPK is a ubiquitous energy sensor of the eukaryotic cell. Thus, AMPK has been studied in many different cellular signaling pathways and specific methodology was applied to elucidate various processes of interest, such as cell growth, autophagy, metabolism and gene transcription $(14,40,41)$. Here, we introduce the common starting points used in AMPK cellular signaling research by focusing on metabolic stressors and 


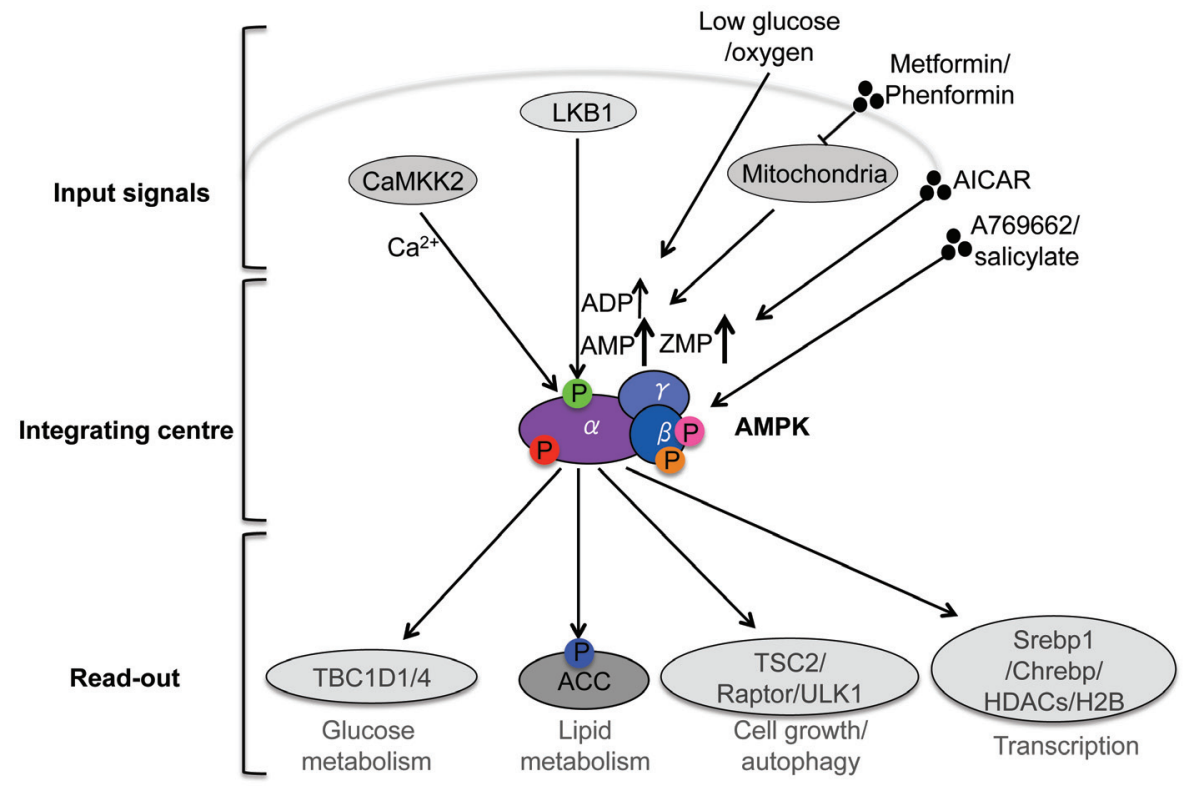

Figure 4. AMPK in the context of cellular signaling studies. The depicted AMPK cellular signaling model comprises three conceptual levels: input signal/activation (by upstream regulatory molecules), AMPK as a signal sensor and convergence/integration point of signaling and downstream targets (biological/functional read-out). As input signals, metabolic stress, like low glucose or oxygen and small molecule activators metformin/phenformin lead to increased cellular AMP/ADP, whereas AICAR forms AICAR-phosphate (ZMP), a structural analog of AMP. Thus LKB1 directly phosphorylates AMPK at T172 for activation, while CaMKK2 activates AMPK in response to calcium influx. Activity of AMPK is increased by activating phosphorylation, and/or pharmacologically, by binding of A769662/ salicylate. The phosphorylation status of AMPK downstream targets changes in response to AMPK activation. As read-out for AMPK activity changes, phosphorylation status of ACC at S79 is most commonly detected, i.e., using commercially available antibodies. Phosphorylation of other substrates, involving in glucose metabolism, cell growth/autophagy and transcription, may also be used as biological endpoints.

pharmacological compounds as input signals, AMPK as the integrating centre and downstream substrates as read-out (Figure 4).

\section{AMPK isoforms and cell models}

In principle, any eukaryotic cell is expected to express AMPK (or a close homologue) and thus can serve as a cell model. However, the composition of the heterotrimeric AMPK and the level of subunit expression and incorporation show differences in a cell type specific context and also at the level of activation, interestingly. In mice, the distribution of different isoforms is well defined: $\alpha 1$ evenly presents across heart, liver, kidney, brain, spleen, lung and skeletal muscle, while $\alpha 2$ is most abundant in heart and skeletal muscle; similarly, the $\beta 2$ subunit is expressed in the same muscular tissues whereas the $\beta 1$ isoform is ubiquitous; $\gamma 1$ and $\gamma 2$ are widely expressed with $\gamma 2$ levels highest in heart, while the $\gamma 3$ isoform is restricted to skeletal muscle (14). These 
observations, therefore, emphasize the importance of choice of a relevant cell model with respect to specific signaling studies and organs. Also, AMPK $\alpha 2$ subunit has been shown with preferential nuclear localization and therefore is more indicated to be involved in transcriptional regulation (42). Studies into processes that depend on AMPK activation often apply HeLa cells, due to their lack of LKB1 (43). Likewise, neurons (44) and T cells (45) are explored for the role of CaMKK2 on AMPK activity. Therefore the AMPK activating mechanisms and controls may differ per cell type and so does the spectrum of AMPK downstream targets.

\section{Physiological and pharmacological modulators of AMPK activity}

AMPK promotes ATP generation in response to increased AMP and ADP levels and thus various metabolic stressors, such as low oxygen or nutrient deprivation, induce AMPK activation (41). In particular, glucose deprivation has been applied to cells in order to activate AMPK. In response to such energy stress, LKB1 directly phosphorylates AMPK at threonine 172 (T172) $(27,43,46)$. CaMKK2, on the other hand, activates AMPK by targeting the same site upon increased calcium influx $(47,48)$. For example, in endothelial cells thrombin has been shown to activate AMPK in a CaMKK2-dependent manner (23).

The compound 5-Aminoimidazole-4-carboxamide ribonucleotide (AICAR) is phosphorylated intracellularly to form AICAR-phosphate (ZMP), a structural analog of AMP, thus capable of activating AMPK and widely used as AMPK activator in cell studies (49). Metformin and phenformin are found to induce AMPK activation via inhibiting mitochondrial ATP synthesis (50) and therefore increasing the cellular AMP-to-ATP ratio. By directly binding to AMPK, A769662 (51) and salicylate (52) induce allosteric activation of AMPK and thus are increasingly used for AMPK cellular function analysis. Importantly, A769662-mediated AMPK activation was also found to reduce the metastatic efficiency of breast tumour cells (53), illustrating the potential clinical importance of both AMPK and small molecule activating compounds. To inhibit AMPK activity, compound $\mathrm{C}$ has been utilized as an ATP-competitor. However, compound C (and other kinase inhibitors) lack specificity for AMPK (54). Although compound C undoubtedly inhibits AMPK and may still be considered useful, the experimental results obtained from using this inhibitor thus should be interpreted with caution. The CaMKK inhibitor STO-609 has been applied in studies of CaMKK2-mediated AMPK activation (48). Inhibitors of LKB1 have remained elusive.

\section{AMPK as the integrating centre for activity modulation}

(1) Antibodies for AMPK activity measurement in cells

Phosphorylation sites in AMPK have been reported in $\alpha$ and $\beta$ subunits mainly and site-specific phosphorylation-sensitive antibodies have been generated against several 
sites. Phospho-AMPK $\alpha$ threonine 172 (pT172) antiserum is commonly used as an indicator of AMPK activity status (55). Phosphorylation at serine 485 ( $\alpha 1$ ) / serine 491 (a2) can also be detected by phospho-specific antibodies and was linked to AMPK inhibition (56). In the CBM of $\beta$ subunit, serine 108 phosphorylation has been monitored by a specific antibody to explore the activation mechanism of small molecule activators (20). Although the role of phosphorylation at serine 182 in $\beta 1$ subunit is not well defined yet, phospho-specific antibody is also commercially available. Several research groups also developed their own antibodies, such as the phospho-AMPK $\beta$ threonine 148 (pT148) antibody (7), which have remained non-commercial.

(2) Genetic intervention for AMPK activity modulation

In addition to pharmacological activation or inhibition, AMPK activity can be modulated by molecular genetic intervention to study and validate its biological relevance in a certain process. As discussed above (section 1.3) AMPK can be expressed in cell models using transient transfection or viral transduction approaches. The expression of available and novel AMPK (subunit) mutants allows analysis of the involvement of specific protein domains or PTMs in regard to a cellular response. Mutation of aspartate 157 to alanine (D157A) within the $\alpha 1$ subunit renders AMPK catalytically inactive (57). Constitutively active (CA-AMPK) and dominant negative (DNAMPK) forms were generated by mutating the threonine residue at 172 into an aspartic acid (T172D) and an alanine (T172A), respectively $(58,59)$. Mutation of serine 485 within the $\alpha 1$ subunit into alanine (S485A) has been used to study possible suppressive signaling pathways of AMPK function (60). Deletion mutant analysis of the $\alpha 1$ subunit was designed to locate specific binding regions for its binding partners (61). Likewise, an autophosphorylation site mutant at serine 108 in $\beta$ subunit (S108A) was used to study the mechanism by which A769662 activates AMPK (62). An isolated carbohydratebinding module (CBM) located in the $\beta$ subunit and $\beta$ threonine 148 mutant (T148A) was used in AMPK-glycogen binding study (7). Interestingly, mutation of arginine 531 into glycine (R531G) in the $\gamma 2$ subunit, which is also found in Wolff-Parkinson-White (WPW) syndrome, causes a lack of AMP/ADP binding (63) and thus has been used as an AMPinsensitive mutant to distinguish upstream activating signals of AMPK that are not requiring elevated $\mathrm{AMP}$ levels (64).

Loss of AMPK function can be obtained genetically (knock-out/knock-down) by use of gene-targeting technology or the use of RNA interference-based post-transcriptional silencing approaches, respectively. To date, various knock-out mice lacking AMPK specific subunits have been created, which are valuable sources for genetically altered cell systems in in-vitro studies. Notably, the animal-derived cell lines can be used in the primary constitution (65) or immortalized to establish novel cellular models, e.g., 
AMPKa-deficient immortalized mouse embryonic fibroblasts (MEFs) were derived from AMPK $\alpha 1$ and $\alpha 2$ double-knockouts mice (66). To achieve AMPK knock-down, small interfering RNA (siRNA) and short hairpin RNA (shRNA) have been developed and verified mainly for $\alpha$ subunit: $\alpha 1$ and $\alpha 2$ subunits knock-down was effectively achieved in both human and mouse cells by siRNA or shRNA, by targeting a completely conserved sequence among human, mouse and rat AMPK (67). In muscle cells, AMPK knock-down has been achieved by both siRNA (68) and lentiviral shRNA (59). Commercial siRNA and shRNA are also available and have been verified in some studies $(69,70)$.

\section{Downstream targets as study read-out}

With increasing knowledge of AMPK signaling network, multiple downstream targets in different pathways have been well studied and established as indicators of AMPK activity. Among all the substrates, acetyl-CoA carboxylase (ACC), a regulator in fatty acid synthesis, is most commonly used. Serine 79 in ACC was identified as the AMPK phosphorylation site (71), and phospho-ACC serine 79 (pS79) has since then been used as a general indicator of the effect of various treatments on AMPK activity $(72,73)$. In cell growth signaling, phosphorylation of tumour suppressor tuberous sclerosis complex 2 (TSC2) $(74,75)$ and regulatory-associated protein of mechanistic target of rapamycin (Raptor) (34) have been associated with the inhibitory effect of AMPK on mechanistic target of rapamycin complex 1 (mTORC1). As downstream targets of mTORC1, phosphorylation of p70S6K1 (Thr389) and 4E-BP1 (Ser65) have also been utilized to check the net of effect of AMPK signaling changes (34). In autophagy, a direct connection between AMPK and phosphorylation of the ULK1 complex was reported (76). In the context of signaling pathways in glucose uptake, phosphorylation of TBC1 domain family member 1 and 4 (TBC1D1/4) has been used as read-out of AMPK involvement $(77,78)$. Further, the role of AMPK in metabolism has been revealed in transcriptional control as well, via directly phosphorylating the lipogenic transcription factor sterol regulatory element-binding transcription factor 1 (Srebp1) (79), the glucose-sensitive transcription factor carbohydrate-responsive element-binding protein (Chrebp) (80), histone deacetylases (HDACs) 4/5/7/9 (81) and histone 2B (H2B) (66).

\section{Perspectives}

Application of up-to-date biochemical and molecular biology techniques has been a major driver of research progress in the AMPK field. Implementation of novel technologies will facilitate advanced insight into AMPK function and functioning in the near future. With the CRISPR/Cas methodology on the rise, it is expected that the nuclear encoded expression of AMPK variants in various cell systems will become available at a much-accelerated rate, i.e., independent of the availability of a corresponding genetic 
mouse model. Thus, functional knockouts, domain and single-site mutants of the endogenous gene can be created by CRISPR/Cas-mediated genome editing to study their cellular effect. Super-resolution microscopy could facilitate the study of AMPK at subcellular and organelle-level, thereby providing insight into AMPK-function in relation to localization. Further, the application of imaging mass spectrometry will allow for analysis of AMPK in biological specimen to provide positional information in combination with identification of neighbouring molecules and/or posttranslational modifications of AMPK. Advancement in chemical genetics may further enhance the study of regulatory pathways and elucidation of causal relationships to AMPK. In conclusion, a new wave of in vitro and in vivo methods is awaiting implementation in the context of AMPK research. Such new data is expected to significantly contribute to the scientific advancement of the AMPK field and can be crucial for clinical application of novel AMPK modulators. 


\section{References:}

1. Neumann, D., Woods, A., Carling, D., Wallimann, T., and Schlattner, U. (2003) Protein Expr Purif 30, 230-237

2. Rajamohan, F., Harris, M. S., Frisbie, R. K., Hoth, L. R., Geoghegan, K. F., Valentine, J. J., Reyes, A. R., Landro, J. A., Qiu, X., and Kurumbail, R. G. (2010) Protein Expr Purif 73, 189-197

3. Kukimoto-Niino, M., Yoshikawa, S., Takagi, T., Ohsawa, N., Tomabechi, Y., Terada, T., Shirouzu, M., Suzuki, A., Lee, S., Yamauchi, T., OkadaIwabu, M., Iwabu, M., Kadowaki, T., Minokoshi, Y., and Yokoyama, S. (2011) J Biol Chem 286, 22570-22579

4. Suter, M., Riek, U., Tuerk, R., Schlattner, U., Wallimann, T., and Neumann, D. (2006) J Biol Chem 281, 32207-32216

5. Neumann, D., Suter, M., Tuerk, R., Riek, U., and Wallimann, T. (2007) Molecular biotechnology 36, 220-231

6. Bullen, J. W., Balsbaugh, J. L., Chanda, D., Shabanowitz, J., Hunt, D. F., Neumann, D., and Hart, G. W. (2014) J Biol Chem 289, 1059210606

7. Oligschlaeger, Y., Miglianico, M., Chanda, D., Scholz, R., Thali, R. F., Tuerk, R., Stapleton, D. I., Gooley, P. R., and Neumann, D. (2015) J Biol Chem 290, 11715-11728

8. Riek, U., Scholz, R., Konarev, P., Rufer, A., Suter, M., Nazabal, A., Ringler, P., Chami, M., Muller, S. A., Neumann, D., Forstner, M., Hennig, M., Zenobi, R., Engel, A., Svergun, D., Schlattner, U., and Wallimann, T. (2008) J Biol Chem 283, 18331-18343

9. Riek, U., Ramirez, S., Wallimann, T., and Schlattner, U. (2009) BioTechniques 46, ix-xii

10. Jarvis, D. L. (2009) Methods in enzymology 463, 191-222

11. Ramanathan, L., Sheth, P. R., Ogas, P., Xiao, L., and Le, H. V. (2010) Protein Expr Purif 70, 13-22

12. Iseli, T. J., Oakhill, J. S., Bailey, M. F., Wee, S., Walter, M., van Denderen, B. J., Castelli, L. A., Katsis, F., Witters, L. A., Stapleton, D., Macaulay, S. L., Michell, B. J., and Kemp, B. E. (2008) J Biol Chem 283, 4799-4807

13. Oakhill, J. S., Chen, Z. P., Scott, J. W., Steel, R., Castelli, L. A., Ling, N., Macaulay, S. L., and Kemp, B. E. (2010) Proc Natl Acad Sci U S A 107, 19237-19241

14. Steinberg, G. R., and Kemp, B. E. (2009) Physiol Rev 89, 1025-1078

15. Carling, D., Clarke, P. R., Zammit, V. A., and Hardie, D. G. (1989) Eur J Biochem 186, 129-136

16. Davies, S. P., Hawley, S. A., Woods, A., Carling, D., Haystead, T. A., and Hardie, D. G. (1994) Eur J Biochem 223, 351-357
17. Michell, B. J., Stapleton, D., Mitchelhill, K. I., House, C. M., Katsis, F., Witters, L. A., and Kemp, B. E. (1996) J Biol Chem 271, 28445-28450

18. Turban, S., Stretton, C., Drouin, O., Green, C. J., Watson, M. L., Gray, A., Ross, F., Lantier, L., Viollet, B., Hardie, D. G., Marette, A., and Hundal, H. S. (2012) J Biol Chem 287, 2008820099

19. Dyck, J. R., Gao, G., Widmer, J., Stapleton, D., Fernandez, C. S., Kemp, B. E., and Witters, L. A. (1996) J Biol Chem 271, 17798-17803

20. Scott, J. W., Ling, N., Issa, S. M., Dite, T. A., O’Brien, M. T., Chen, Z. P., Galic, S., Langendorf, C. G., Steinberg, G. R., Kemp, B. E., and Oakhill, J. S. (2014) Chem Biol 21, 619-627

21. Kim, T. K., and Eberwine, J. H. (2010) Anal Bioanal Chem 397, 3173-3178

22. Khan, K. H. (2013) Adv Pharm Bull 3, 257-263

23. Stahmann, N., Woods, A., Carling, D., and Heller, R. (2006) Molecular and cellular biology 26, 5933-5945

24. Ma, H., Deacon, S., and Horiuchi, K. (2008) Expert opinion on drug discovery 3, 607-621

25. Davies, S. P., Carling, D., and Hardie, D. G. (1989) Eur J Biochem 186, 123-128

26. Salt, I. P., Johnson, G., Ashcroft, S. J., and Hardie, D. G. (1998) Biochem J 335 ( Pt 3), 533-539

27. Shaw, R. J., Kosmatka, M., Bardeesy, N., Hurley, R. L., Witters, L. A., DePinho, R. A., and Cantley, L. C. (2004) Proc Natl Acad Sci U S A 101, 33293335

28. Xiao, B., Sanders, M. J., Underwood, E., Heath, R., Mayer, F. V., Carmena, D., Jing, C., Walker, P. A., Eccleston, J. F., Haire, L. F., Saiu, P., Howell, S. A., Aasland, R., Martin, S. R., Carling, D., and Gamblin, S. J. (2011) Nature 472, 230-233

29. Xiao, B., Sanders, M. J., Carmena, D., Bright, N. J., Haire, L. F., Underwood, E., Patel, B. R., Heath, R. B., Walker, P. A., Hallen, S., Giordanetto, F., Martin, S. R., Carling, D., and Gamblin, S. J. (2013) Nat Commun 4, 3017

30. Koay, A., Woodcroft, B., Petrie, E. J., Yue, H., Emanuelle, S., Bieri, M., Bailey, M. F., Hargreaves, M., Park, J. T., Park, K. H., Ralph, S., Neumann, D., Stapleton, D., and Gooley, P. R. (2010) FEBS Lett 584, 3499-3503

31. Calabrese, M. F., Rajamohan, F., Harris, M. S., Caspers, N. L., Magyar, R., Withka, J. M., Wang, H., Borzilleri, K. A., Sahasrabudhe, P. V., Hoth, L. R., Geoghegan, K. F., Han, S., Brown, J., Subashi, T. A., Reyes, A. R., Frisbie, R. K., Ward, J., Miller, R. A., Landro, J. A., Londregan, A. T., Carpino, P. A., Cabral, S., Smith, A. C., Conn, E. L., Cameron, K. O., Qiu, X., and Kurumbail, R. G. (2014) Structure 22, 1161-1172 
32. Tuerk, R. D., Thali, R. F., Auchli, Y., Rechsteiner, H., Brunisholz, R. A., Schlattner, U., Wallimann, T., and Neumann, D. (2007) J Proteome Res 6, 3266-3277

33. Thali, R. F., Tuerk, R. D., Scholz, R., Yoho-Auchli, Y., Brunisholz, R. A., and Neumann, D. (2010) Biochem Biophys Res Commun 398, 296-301

34. Gwinn, D. M., Shackelford, D. B., Egan, D. F., Mihaylova, M. M., Mery, A., Vasquez, D. S., Turk, B. E., and Shaw, R. J. (2008) Molecular cell 30, 214-226

35. Ducommun, S., Deak, M., Sumpton, D., Ford, R. J., Nunez Galindo, A., Kussmann, M., Viollet, B., Steinberg, G. R., Foretz, M., Dayon, L., Morrice, N. A., and Sakamoto, K. (2015) Cell Signal 27, 978-988

36. Banko, M. R., Allen, J. J., Schaffer, B. E., Wilker, E. W., Tsou, P., White, J. L., Villen, J., Wang, B., Kim, S. R., Sakamoto, K., Gygi, S. P., Cantley, L. C., Yaffe, M. B., Shokat, K. M., and Brunet, A. (2011) Molecular cell 44, 878-892

37. Klaus, A., Zorman, S., Berthier, A., Polge, C., Ramirez, S., Michelland, S., Seve, M., Vertommen, D., Rider, M., Lentze, N., Auerbach, D., and Schlattner, U. (2013) PLoS One 8, e62497

38. Zhan, Y. Y., Chen, Y., Zhang, Q., Zhuang, J. J., Tian, M., Chen, H. Z., Zhang, L. R., Zhang, H. K., He, J. P., Wang, W. J., Wu, R., Wang, Y., Shi, C., Yang, K., Li, A. Z., Xin, Y. Z., Li, T. Y., Yang, J. Y., Zheng, Z. H., Yu, C. D., Lin, S. C., Chang, C., Huang, P. Q., Lin, T., and Wu, Q. (2012) Nat Chem Biol 8, 897-904

39. Sanz, P., Rubio, T., and Garcia-Gimeno, M. A. (2013) Febs J 280, 3723-3733

40. Hardie, D. G., Ross, F. A., and Hawley, S. A. (2012) Nat Rev Mol Cell Biol 13, 251-262

41. Mihaylova, M. M., and Shaw, R. J. (2011) Nat Cell Biol 13, 1016-1023

42. Salt, I., Celler, J. W., Hawley, S. A., Prescott, A., Woods, A., Carling, D., and Hardie, D. G. (1998) Biochem J 334 ( Pt 1), 177-187

43. Hawley, S. A., Boudeau, J., Reid, J. L., Mustard, K. J., Udd, L., Makela, T. P., Alessi, D. R., and Hardie, D. G. (2003) Journal of biology 2, 28

44. Anderson, K. A., Ribar, T. J., Lin, F., Noeldner, P. K., Green, M. F., Muehlbauer, M. J., Witters, L. A., Kemp, B. E., and Means, A. R. (2008) Cell Metab 7, 377-388

45. Tamas, P., Hawley, S. A., Clarke, R. G., Mustard, K. J., Green, K., Hardie, D. G., and Cantrell, D. A. (2006) J Exp Med 203, 1665-1670

46. Woods, A., Johnstone, S. R., Dickerson, K., Leiper, F. C., Fryer, L. G., Neumann, D., Schlattner, U., Wallimann, T., Carlson, M., and Carling, D. (2003) Current biology : CB 13, 20042008
47. Hawley, S. A., Pan, D. A., Mustard, K. J., Ross, L., Bain, J., Edelman, A. M., Frenguelli, B. G., and Hardie, D. G. (2005) Cell Metab 2, 9-19

48. Hurley, R. L., Anderson, K. A., Franzone, J. M., Kemp, B. E., Means, A. R., and Witters, L. A. (2005) J Biol Chem 280, 29060-29066

49. Guo, D., Hildebrandt, I. J., Prins, R. M., Soto, H., Mazzotta, M. M., Dang, J., Czernin, J., Shyy, J. Y., Watson, A. D., Phelps, M., Radu, C. G., Cloughesy, T. F., and Mischel, P. S. (2009) Proc Natl Acad Sci U S A 106, 12932-12937

50. Andrzejewski, S., Gravel, S. P., Pollak, M., and StPierre, J. (2014) Cancer \& metabolism 2, 12

51. Cool, B., Zinker, B., Chiou, W., Kifle, L., Cao, N., Perham, M., Dickinson, R., Adler, A., Gagne, G., lyengar, R., Zhao, G., Marsh, K., Kym, P., Jung, P., Camp, H. S., and Frevert, E. (2006) Cell Metab 3, 403-416

52. Hawley, S. A., Fullerton, M. D., Ross, F. A., Schertzer, J. D., Chevtzoff, C., Walker, K. J., Peggie, M. W., Zibrova, D., Green, K. A., Mustard, K. J., Kemp, B. E., Sakamoto, K., Steinberg, G. R., and Hardie, D. G. (2012) Science 336, 918-922

53. Chakrabarti, K. R., Whipple, R. A., Boggs, A. E., Hessler, L. K., Bhandary, L., Vitolo, M. I., Thompson, K., and Martin, S. S. (2015) Oncotarget

54. Liu, X., Chhipa, R. R., Nakano, I., and Dasgupta, B. (2014) Mol Cancer Ther 13, 596-605

55. Hawley, S. A., Davison, M., Woods, A., Davies, S. P., Beri, R. K., Carling, D., and Hardie, D. G. (1996) J Biol Chem 271, 27879-27887

56. Suzuki, T., Bridges, D., Nakada, D., Skiniotis, G., Morrison, S. J., Lin, J. D., Saltiel, A. R., and Inoki, K. (2013) Molecular cell 50, 407-419

57. Woods, A., Vertommen, D., Neumann, D., Turk, R., Bayliss, J., Schlattner, U., Wallimann, T., Carling, D., and Rider, M. H. (2003) J Biol Chem 278, 28434-28442

58. Vingtdeux, V., Giliberto, L., Zhao, H., Chandakkar, P., Wu, Q., Simon, J. E., Janle, E. M., Lobo, J., Ferruzzi, M. G., Davies, P., and Marambaud, P. (2010) J Biol Chem 285, 9100-9113

59. Turban, S., Stretton, C., Drouin, O., Green, C. J., Watson, M. L., Gray, A., Ross, F., Lantier, L., Viollet, B., Hardie, D. G., Marette, A., and Hundal, H. S. (2012) J Biol Chem 287, 2008820099

60. Ning, J., Xi, G., and Clemmons, D. R. (2011) Endocrinology 152, 3143-3154

61. Lee, K. M., Jo, S., Kim, H., Lee, J., and Park, C. S. (2011) Biochimica et biophysica acta 1813, 448455

62. Sanders, M. J., Ali, Z. S., Hegarty, B. D., Heath, R., Snowden, M. A., and Carling, D. (2007) J Biol Chem 282, 32539-32548 
63. Scott, J. W., Hawley, S. A., Green, K. A., Anis, M., Stewart, G., Scullion, G. A., Norman, D. G., and Hardie, D. G. (2004) J Clin Invest 113, 274-284

64. Hawley, S. A., Ross, F. A., Chevtzoff, C., Green, K. A., Evans, A., Fogarty, S., Towler, M. C., Brown, L. J., Ogunbayo, O. A., Evans, A. M., and Hardie, D. G. (2010) Cell Metab 11, 554-565

65. Foretz, M., Hebrard, S., Leclerc, J., Zarrinpashneh, E., Soty, M., Mithieux, G., Sakamoto, K., Andreelli, F., and Viollet, B. (2010) J Clin Invest 120, 2355-2369

66. Bungard, D., Fuerth, B. J., Zeng, P. Y., Faubert, B., Maas, N. L., Viollet, B., Carling, D., Thompson, C. B., Jones, R. G., and Berger, S. L. (2010) Science 329, 1201-1205

67. Tangeman, L., Wyatt, C. N., and Brown, T. L. (2012) Journal of RNAi and gene silencing : an international journal of RNA and gene targeting research 8, 470-478

68. Aguilar, V., Alliouachene, S., Sotiropoulos, A., Sobering, A., Athea, Y., Djouadi, F., Miraux, S., Thiaudiere, E., Foretz, M., Viollet, B., Diolez, P., Bastin, J., Benit, P., Rustin, P., Carling, D., Sandri, M., Ventura-Clapier, R., and Pende, M. (2007) Cell Metab 5, 476-487

69. Harhaji-Trajkovic, L., Vilimanovich, U., KravicStevovic, T., Bumbasirevic, V., and Trajkovic, V. (2009) J Cell Mol Med 13, 3644-3654

70. Zhou, J., Huang, W., Tao, R., Ibaragi, S., Lan, F., Ido, Y., Wu, X., Alekseyev, Y. O., Lenburg, M. E., Hu, G. F., and Luo, Z. (2009) Oncogene 28, 19932002

71. Ha, J., Daniel, S., Broyles, S. S., and Kim, K. H. (1994) J Biol Chem 269, 22162-22168

72. Sujobert, P., Poulain, L., Paubelle, E., Zylbersztejn, F., Grenier, A., Lambert, M., Townsend, E. C., Brusq, J. M., Nicodeme, E., Decrooqc, J., Nepstad, I., Green, A. S., Mondesir, J., Hospital, M. A., Jacque, N., Christodoulou, A., Desouza, T. A., Hermine, O., Foretz, M., Viollet,
B., Lacombe, C., Mayeux, P., Weinstock, D. M., Moura, I. C., Bouscary, D., and Tamburini, J. (2015) Cell reports 11, 1446-1457

73. Hoogendijk, A. J., Pinhancos, S. S., van der Poll, T., and Wieland, C. W. (2013) J Biol Chem 288, 7047-7052

74. Inoki, K., Zhu, T., and Guan, K. L. (2003) Cell 115, 577-590

75. Shaw, R. J., Bardeesy, N., Manning, B. D., Lopez, L., Kosmatka, M., DePinho, R. A., and Cantley, L. C. (2004) Cancer cell 6, 91-99

76. Hardie, D. G. (2011) Embo J 30, 634-635

77. Treebak, J. T., Glund, S., Deshmukh, A., Klein, D. K., Long, Y. C., Jensen, T. E., Jorgensen, S. B., Viollet, B., Andersson, L., Neumann, D. Wallimann, T., Richter, E. A., Chibalin, A. V., Zierath, J. R., and Wojtaszewski, J. F. (2006) Diabetes 55, 2051-2058

78. Taylor, E. B., An, D., Kramer, H. F., Yu, H., Fujii, N. L., Roeckl, K. S., Bowles, N., Hirshman, M. F., Xie, J., Feener, E. P., and Goodyear, L. J. (2008) J Biol Chem 283, 9787-9796

79. Li, Y., Xu, S., Mihaylova, M. M., Zheng, B., Hou, X., Jiang, B., Park, O., Luo, Z., Lefai, E., Shyy, J. Y., Gao, B., Wierzbicki, M., Verbeuren, T. J., Shaw, R. J., Cohen, R. A., and Zang, M. (2011) Cell Metab 13, 376-388

80. Kawaguchi, T., Osatomi, K., Yamashita, H., Kabashima, T., and Uyeda, K. (2002) J Biol Chem 277, 3829-3835

81. McGee, S. L., van Denderen, B. J., Howlett, K. F., Mollica, J., Schertzer, J. D., Kemp, B. E., and Hargreaves, M. (2008) Diabetes 57, 860-867 



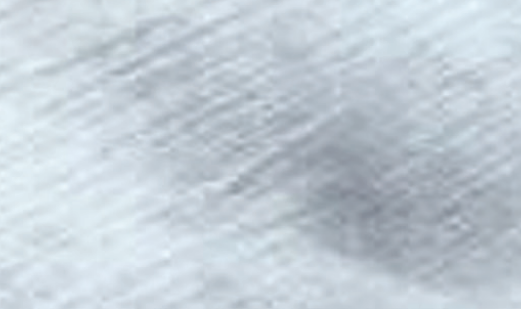

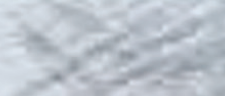
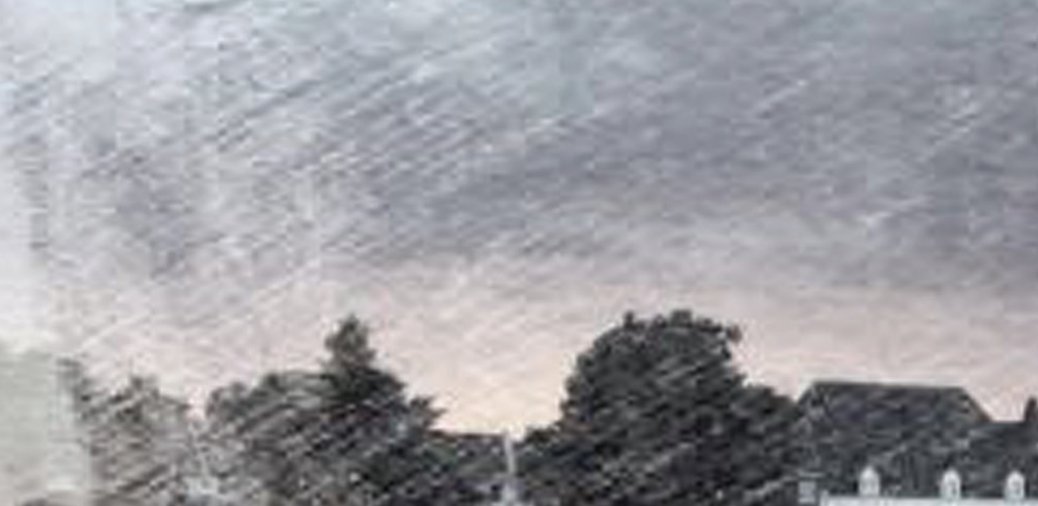

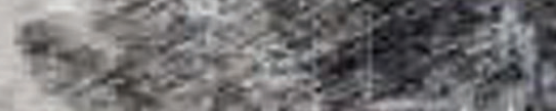

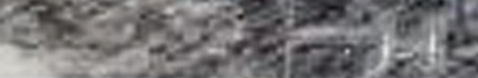

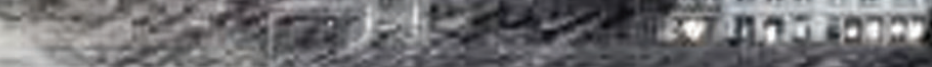

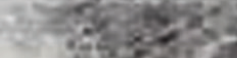

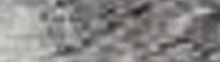

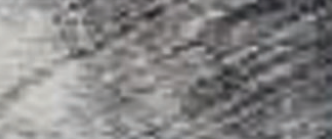

of

if $25=0$

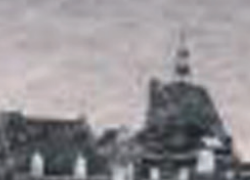




\title{
Chapter 3
}

\section{AMP-activated protein kinase upregulates MAP kinase interacting serine/threonine kinase 1a-dependent phosphorylation of eukaryotic translation initiation factor $4 \mathrm{E}$}

\author{
Xiaoqing Zhu ${ }^{1}$, Vivian Dahlmans ${ }^{2}$, Ramon Thali ${ }^{3}$, Christian Preisinger', \\ Benoit Viollet ${ }^{5,6,7}$, J. Willem Voncken ${ }^{2 \#}$, Dietbert Neumann ${ }^{1,3 \#}$
}

\begin{abstract}
${ }^{1}$ Dept. of Molecular Genetics, CARIM School of Cardiovascular Diseases; ${ }^{2}$ Dept. of Molecular Genetics, Maastricht University Medical Center, Maastricht, the Netherlands; ${ }^{3}$ Institute of Cell Biology, ETH Zurich, 8093 Zurich, Switzerland; " ${ }^{P}$ roteomics Facility, Interdisciplinary Center for Clinical Research (IZKF), RWTH University Hospital Aachen, Germany; ${ }^{5}$ Institut Cochin, INSERM U1016, Dpt. of Endocrinology, Metabolism and Diabetes, Paris, France; ${ }^{6}$ CNRS UMR 8104, Paris, France; ${ }^{7}$ Université Paris Descartes, Sorbonne Paris Cité, Paris, France.
\end{abstract}

\# These authors contributed equally

To whom correspondence should be addressed: D. Neumann, Dept. of Molecular Genetics, CARIM School for Cardiovascular Diseases, Maastricht University, 6200 MD Maastricht, The Netherlands, Tel.: +31(43)388-1851; Fax.: +31(43)388-4574;

E-mail:d.neumann@maastrichtuniversity.nl 


\begin{abstract}
AMP-activated protein kinase (AMPK) is a molecular energy sensor that acts to sustain cellular energy balance. Although AMPK is implicated in the regulation of a multitude of ATP-dependent cellular processes, exactly how these processes are controlled by AMPK and the identity of AMPK targets and pathways continues to evolve. We here identify MAP kinase interacting serine/threonine-protein kinase 1a (MNK1a) as a novel AMPK target. Specifically, we show AMPK-dependent serine 353 (S353) phosphorylation of the human MNK1a isoform in cell-free and cellular systems. We show that AMPK and MNK1a physically interact and that in vivo MNK1a-S353 phosphorylation requires T-loop phosphorylation, in good agreement with a recently proposed structural regulatory model of MNK1a. Our data suggest a physiological role for MNK1a-S353-phosphorylation in regulation of the MNK1a kinase, which correlates with increased eIF4E phosphorylation in vitro and in vivo.
\end{abstract}

Keywords: AMP-activated protein kinase (AMPK), MAP kinase interacting serine/ threonine kinase 1a (MNK1a), phosphorylation, translation, elF4E, post-translational modification 


\section{Introduction}

Balancing catabolic and anabolic processes is fundamental to energy homeostasis and metabolic adaptation. The $\alpha \beta \gamma$ heterotrimeric AMP-activated protein kinase (AMPK) promotes ATP-production and limits ATP-consumption (1,2). Shifts in the cellular AMP:ATP ratio are detected through the $\gamma$ subunit, which cooperatively binds AMP. Consequential conformational changes within the heterotrimer stimulate AMPK kinase activity. Activation of AMPK further involves threonine 172 (T172) phosphorylation in the activation-loop of the a subunit kinase domain (3). Additional (auto)phosphorylation events are known to regulate AMPK (4-6). Through its established roles in lipid, glucose and protein metabolism, AMPK functions at the cross roads of energy metabolism and basic cellular processes including cell proliferation, growth and survival (7-9). For example, AMPK-mediated regulation of acetyl CoA carboxylases ACC1 and ACC2 accelerates fatty acid synthesis and inhibits fatty acid oxidation, respectively (10). AMPK is involved in control of cell growth via phosphorylation of regulatory-associated protein of mTOR (Raptor) and tuberous sclerosis 2 (TSC2, tumor suppressor) $(11,12)$.

Despite its well-known role as energy sensor, a lack of knowledge on the identity of direct AMPK targets and thus of pathways involved in these processes persists. A substantial amount of functional screening approaches have been developed to identify AMPK downstream targets and interaction partners (13-17). High-density protein microarrays enable the rapid identification of potentially novel human kinase substrates at a proteomic scale (18). Using this strategy we identified MAP-kinase interacting serine/ threonine-protein kinase 1 (MNK1) as a putative novel AMPK target (19). The human MKNK1 gene encodes two splice variants, MNK1a and MNK1b, which differ in their Cterminal sequences. In contrast to other MNKs, MNK1a has low basal activity and is highly induced upon activation (20). MNK1a is activated by Mitogen and Stress Activated Protein Kinases (M/SAPK) ERK (Extracellular-signaling Regulated Kinase) and P38, via phosphorylation of two threonine residues (T209 and T214) within the activation/T-loop $(21,22)$. MNK1 and MNK2 isoforms phosphorylate the eukaryotic translation initiation factor and mRNA cap-binding protein 4E (elF4E) on serine 209 (23-25). Although the exact biological relevance of this phosphorylation event is still under debate, cellular elF4E plays an important role in the regulation of mRNA translation, in which interaction with the $5^{\prime}$-cap structure of mRNA appears pivotal (26). Deregulation of elF4E has been linked to tumorigenesis $(26,27)$; inhibition of protein translation, e.g. via MNK, is considered for cancer treatment (20).

Here we show that MNK1a is a genuine AMPK target in vitro and in vivo. MNK1a phosphorylation at S353 by AMPK increases its kinase activity toward elF4E phosphorylation. The relevance of our findings for human metabolic and neoplastic 
conditions is discussed.

\section{Results}

\section{MNK1a is a novel AMPK target in vitro}

The online tool (http://scansite3.mit.edu) predicted the presence of a putative AMPK phosphorylation motif LQRNSSTMDL in MNK1a; this domain is absent in MNK1b. The putative AMPK-target site in this motif, S353, is evolutionarily highly conserved among mammals and lower vertebrates (Fig. $1 \boldsymbol{A}$ ). To validate the initial phospho-protein microarray finding, cell-free in vitro kinase (IVK) assays were performed using recombinant AMPK and MNK1a. Mass spectrometric analysis of in vitro phosphorylated recombinant MNK1aWT, indicated S353 as the primary phospho-site in the MNK1aspecific tryptic peptide sequence NSSTTMDLTLFAAEAIALNR (S353 underlined; localization probability: 74\%; Fig1A). To further probe the specificity of this phospho-event in vitro, the GST-tag was also proteolytically removed from recombinant GST:MNK1a to exclude interference by that GST-tag phosphorylation (28). Both GST:MNK1aWT and MNK1aWT protein were phosphorylated specifically and only in the presence of AMPK (Fig. 1B). The absence of radiolabeled MNK1 ${ }^{\mathrm{WT}}$ protein in AMPK-free control reactions, suggested that MNK1a ${ }^{\text {WT }}$ phosphorylation in vitro was AMPK-dependent and that MNK1a ${ }^{\text {WT }}$ protein did not show auto-phosphorylation under these conditions. A commercially available AMPKsubstrate antiserum which detects a common AMPK-phosphorylated LxRxxpS/pI motif, recognized in vitro phosphorylated $\mathrm{MNK1}^{\mathrm{WT}}$ indicating that MNK1a phosphorylation occurred at an AMPK substrate-like motif (Fig. 1C). Absence of detectable MNK1aWT phosphorylation using a kinase-dead AMPK further corroborated the notion that MNK1phosphorylation is dependent on the kinase activity of AMPK in vitro (Fig. 1D). To definitively identify the phosphorylated MNK1a residue, a recombinant MNK1a S353 to alanine mutant (MNK1a ${ }^{5353 \mathrm{~A}}$ ) was tested in cell-free assays. To exclude the possibility that the neighboring Ser352 residue was phosphorylated by AMPK under these conditions, we also generated a MNK1a ${ }^{\mathrm{S} 352 \mathrm{~A}}$ mutant. Whereas Mnk1a ${ }^{\mathrm{WT}}$ and MNK1a ${ }^{\mathrm{S} 352 \mathrm{~A}}$ were clearly detected by autoradiography, the $\mathrm{MNK}^{\mathrm{S}} \mathrm{S}^{\mathrm{S} 33 \mathrm{~A}}$ mutant protein was not radiolabeled under these conditions (Fig. 1E). Analogously, comparative analysis of MNK1a ${ }^{\text {WT }}$ and

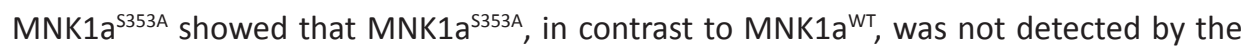
AMPK-substrate antiserum (Fig. 1F). This combined data strongly supports the idea that AMPK phosphorylates MNK1a ${ }^{\mathrm{WT}}$ at $\mathrm{S} 353$ in vitro.

\section{Cellular MNK1a is phosphorylated at S353 upon AMPK activation}

To establish that MNK1a phosphorylation at S353 occurs in living cells, we first compared MNK1a expression levels in different normal diploid and cancer cells. The osteosarcoma cell line U-2OS was found to express endogenous MNK1a at a very low level, whereas its AMPK level was relatively high (Fig. 1G). The functional interaction 
between AMPK and MNK1a was studied in these cells using retrovirally expressed 2PY:MNK1a. Cells were treated with the AMPK-activating compound AICAR; AMPK activity was assessed by PACC1 measurement. Whereas relatively low under control conditions (i.e. non-stimulated or serum-starved), AICAR dramatically increased 2PY:MNK1a ${ }^{\text {WT }}$ phosphorylation at an AMPK substrate-like motif (Fig. $\mathbf{1 H}$ ). Importantly, in contrast to immunoprecipitated (IP-ed) 2PY:MNK1aWT IP-ed 2PY:MNK1a ${ }^{5353 \mathrm{~A}}$ mutant protein did not show any detectable phosphorylation (Fig. $\mathbf{1 H}$ ). This data is congruent with cellular AMPK-mediated phosphorylation of MNK1a at S353.

To be able to study the biological context and relevance of MNK1a-phosphorylation at S353, we generated a polyclonal antiserum specifically recognizing S353phosphorylated MNK1a. Both phosphorylated recombinant GST:MNK1aWT and proteolytically released MNK1aWT were detected by the MNK1a-pS353 antiserum (Fig. 1/). The finding that recombinant GST:MNK1a ${ }^{\mathrm{S} 353 \mathrm{~A}}$ was no longer detectable by the MNK1a-pS353 antiserum under similar assay conditions, corroborated the specificity of the newly generated MNK1a-pS353 antiserum (Fig. 1J). To obtain direct evidence that MNK1a-S353 phosphorylation occurs in living cells, U-2OS cells expressing MNK1aWT or MNK1a $1353 \mathrm{~A}$ were treated with AICAR. As expected, AICAR increased AMPK-pT172 (pAMPK) and ACC1-pS79 (pACC1) in both cell types (Fig. 1K). Importantly, AMPKactivation correlated well with increased MNK1a-pS353 signal; and the MNK1a ${ }^{\mathrm{S} 353 \mathrm{~A}}$ mutant was not recognized by the MNK1a-pS353 antiserum (Fig. 1K).

MNK1a-S353 phosphorylation is AMPK-dependent and involves direct physical interaction

To obtain genetic evidence for the AMPK-dependency of MNK1a-S353 phosphorylation, 2PY:MNK1a-transduced mouse embryonic fibroblasts (MEF) derived from wild type (AMPK ${ }^{\mathrm{WT}}$ ) or $\mathrm{AMPK} \alpha 1 / \alpha 2$ double null-mutant mice (AMPK ${ }^{\mathrm{dKO}}$ ) were either treated with AICAR or A769662; the latter being an AMPK activator with a distinct mode of action (29,30). Both AICAR and A769662 enhanced pAMPK and pACC1 phosphorylation, which correlated well with enhanced MNK1a-S353 phosphorylation in AMPK ${ }^{\mathrm{WT}}$, but not in $\mathrm{AMPK}^{\mathrm{dKO}}$ MEFs (Fig. 2A). These data convincingly support the notion that MNK1a is phosphorylated at Ser353 in an AMPK-dependent fashion in vivo. We then asked whether AMPK physically interacts with MNK1a in living cells. Endogenous AMPK was immunoprecipitated (IP-ed) from 2PY:MNK1aWT U-2OS cells. The interaction between MNK1a was evident under basal conditions and increased dramatically upon AMPK activation by AICAR or glucose deprivation (Fig. 2B). Accordingly, AMPK/MNK1a complex formation is induced in response to AMPK activating stimuli.

Metabolic stress-induced MNK1a-S353 phosphorylation controls its kinase activity toward elF4E

To chart the consequences of AMPK-mediated MNK1a-S353 phosphorylation status 
A

\begin{tabular}{|c|c|c|c|c|c|c|}
\hline \multicolumn{3}{|c|}{ Predicted AMPK phospho-motif: } & LxRxxpS/pT & $\operatorname{xxp} / \mathrm{p} T$ & & \\
\hline MNK1 & \multicolumn{2}{|c|}{ H. sapiens } & \multicolumn{4}{|c|}{ QVLQRNSPSTMDLTLF } \\
\hline MNK1 & \multirow{2}{*}{\multicolumn{2}{|c|}{$\begin{array}{l}\text { M. musculus } \\
\text { R. norvegicus }\end{array}$}} & \multirow{2}{*}{\multicolumn{4}{|c|}{$\begin{array}{l}\text { QVLQRNSpSTMDLTLF } \\
\text { QVLQRNSpSTTMDLTLF }\end{array}$}} \\
\hline MNK1 & & & & & & \\
\hline MNK1 & \multicolumn{2}{|c|}{ B. taurus } & \multicolumn{4}{|c|}{ QVLQRNSpSTMDLTLF } \\
\hline B8XSK1 & \multicolumn{2}{|c|}{ S. scrofa } & \multicolumn{4}{|c|}{ QVLQRNSpSTMDLTLF } \\
\hline Mnk1 & \multicolumn{2}{|c|}{ X. laevis } & \multicolumn{4}{|c|}{ QVLQRNSp\$TMDLTLF } \\
\hline Protein & Position & Gene & Score & Phospho (STY) Probability & - ATP & + ATP \\
\hline Q9BUB5-2 & 353 & MKNK1 & 257.66 & $\mathrm{NS}[0.24) \mathrm{S}(0.74) \mathrm{T}(0.02) \mathrm{MDLTLFAAEAIALNR}$ & 0 & $1.00 \mathrm{E}+08$ \\
\hline
\end{tabular}

B

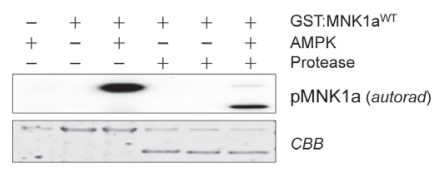

D

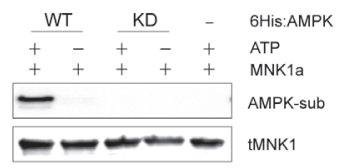

$\mathrm{F}$

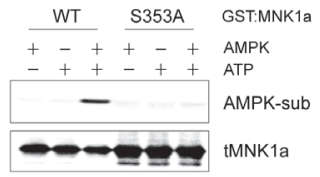

$\mathrm{H}$

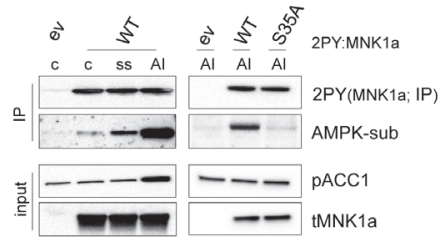

$J$

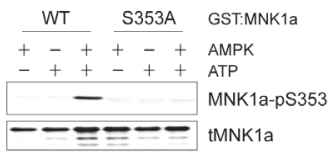

C

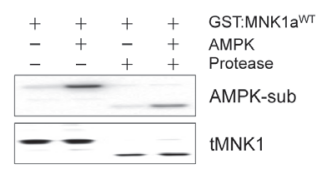

E

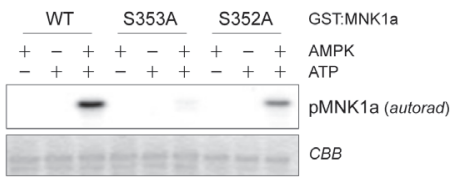

G

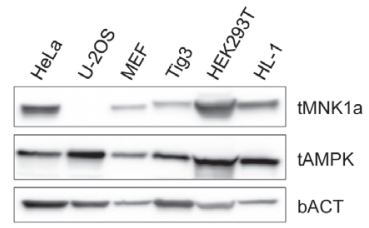

I

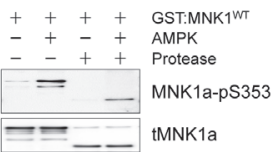

K

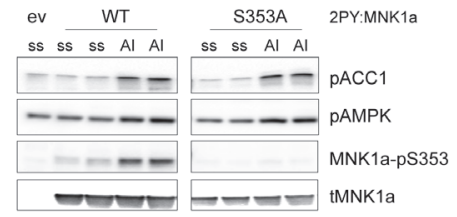

Figure 1. MNK1a-S353 is a novel AMPK target.

(A) (upper panel) Evolutionary conservation of putative MNK1a phosphorylation site. Sequence alignment of MNK1a proteins of human (Q9BUB5), mouse (O08605), rat (Q4G050), bovine (Q58D94), pig (B8XSK1) and Western clawed frog (Q66JF3) (www.uniprot.org). (lower panel) Identification of MNK1a phospho-peptide (aa 351-369; SwissProt: Q9BUB5-2); intensities of phospho-peptide MS spectra in presence or absence of ATP (+/-ATP); probabilities for each phosphorylatable residue are indicated between brackets in the aa sequence.

(B) In vitro kinase assays (IVK): purified GST:MNK1a protein was incubated with or without active AMPK in presence of [ ${ }^{-32}$ P]ATP; protease-mediated removal of the GST-tag was done as indicated. pMNK1a: autoradiograph (upper panel); Coomassie Brilliant Blue-staining (CBB) image: loading control.

(C) IVK assays as in A, using 'cold' ATP instead. Immunoblot detection (IB) of phosphorylated MNK1a using indicated antisera.

(D) As in C: IVK analyses include: active (WT), kinase-dead (KD) or no AMPK; IB detection was done using the indicated antisera. 
(E) IVK: purified recombinant GST:MNK1 $\mathrm{a}^{\mathrm{WT}}$ and mutant GST:MNK1 $\mathrm{a}^{\mathrm{S} 353 \mathrm{~A}}$ or GST:MNK1 $\mathrm{a}^{\mathrm{S} 352 \mathrm{~A}}$ proteins were incubated with active AMPK and [ $\left.\gamma^{-32} \mathrm{P}\right] A T P$. pMNK1a: autoradiograph (upper panel); CBB image: loading control.

(F) As in C: IVK analyses were performed with 'cold' ATP. IB detection was done using the indicated antisera.

(G) MNK1a and AMPK protein levels in HeLa cervical adenocarcinoma, U-2OS, MEF, TIG3 human primary fibroblasts, HEK293T human embryonic kidney, HL-1 immortal murine cardiomyocytes. IB analyses of total cell extracts using the indicated antisera.

(H) U-2OS cells expressing 2PY:MNK1a ${ }^{\mathrm{WT}}$, MNK1a ${ }^{\mathrm{S} 353 \mathrm{~A}}$ (control: empty vector, ev), were treated as indicated (c: control conditions; ss: serum-starved; Al: ss+AICAR). MNK1a was IP-ed using PY antiserum; IB analysis of IP and input material using the indicated antisera.

(I) As in C: IVK analyses using purified recombinant GST:MNK1a ${ }^{\text {WT }}$ protein, active AMPK and 'cold' ATP; protease-mediated removal of the GST-tag as indicated in the figure. IB of phosphorylated MNK1a using the indicated antisera.

(J) As in H: IVK analyses using purified GST:MNK1aWT or GST:MNK1a ${ }^{5353 A}$ with active AMPK and 'cold' ATP. IB was done using the indicated antisera.

(K) U-2OS cells expressing 2PY:MNK1 $\mathrm{a}^{\mathrm{WT}}$, 2PY:MNK1 $\mathrm{a}^{\mathrm{S} 353 \mathrm{~A}}$, or transduced with empty vector (ev), were treated as indicated (serum-starved (ss) or ss+AICAR).

as a function of time, 2PY:MNK1aWT U-2OS cells were glucose-deprived and AMPK and MNK1-phosphorylation were monitored. MNK1a-pS353 and pACC1 were both induced upon glucose deprivation; both phosphorylation events correlated well with AMPK activation (Fig. 2C). Relevantly, 1 hour after replenishment of glucose, cells downregulated MNK1-pS353 and pACC1, in parallel with pAMPK (Fig. 2C). These results are strongly suggestive of direct dynamic control of reversible MNK1a-phosphorylation at S353 by AMPK.

AMPK-activation aims to conserve cellular ATP by tuning energy consuming processes like mRNA translation to metabolic conditions. MNK1 is known to phosphorylate the eukaryotic initiation factor $4 \mathrm{E}$ (eIF4E) at S209, a rate-limiting component of the translation apparatus (31). To explore the potential functional relevance of AMPK-mediated MNK1a-S353 phosphorylation in regards to elF4E-S209 phosphorylation (peIF4E), we compared eIF4E phosphorylation status in the $\mathrm{U}-2 \mathrm{OS}$ model transduced with MNK12 $\mathrm{a}^{\mathrm{S} 353 \mathrm{~A}}$ or MNK1a ${ }^{53535 \mathrm{D}}$ mutants. Cells expressing MNK1a ${ }^{\mathrm{S353D}}$ showed an almost 2-fold increased elF4E phosphorylation at basal levels compared to cells expressing MNK1aWT or MNK1a ${ }^{5353 \mathrm{~A}}$ (Fig. 2D). Combined, these data suggest AMPK-dependent stimulation of MNK1a toward its downstream target elF4E, via MNK1a-S353 phosphorylation.

MNK1-T209/T214 are phosphorylated within the activation T-loop by the M/SAPKs ERK and P38 (21,22). The C-terminus of MNK1a, harboring S353, is thought to play a dual role in the regulation MNK1a kinase activity: the C-terminus acts repressive in the basal state while allowing full stimulation upon ERK/P38-dependent phosphorylation of T209/ T214 (21). To explore the potential functional interdependence of T209/T214 and S353 phosphorylation, we studied specific MNK1a phospho-mutants in U-2OS cells in combination with pharmacological stimulation rather than metabolic stress, as this 
A

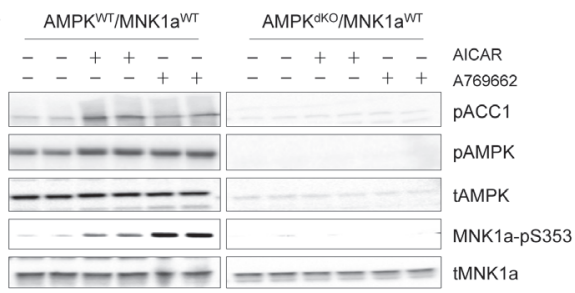

C

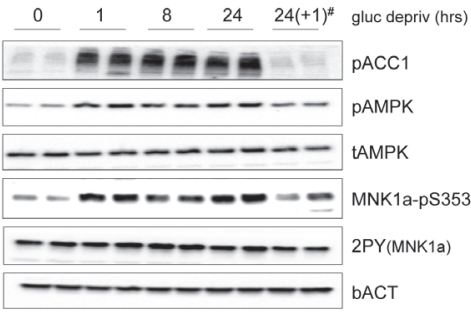

E

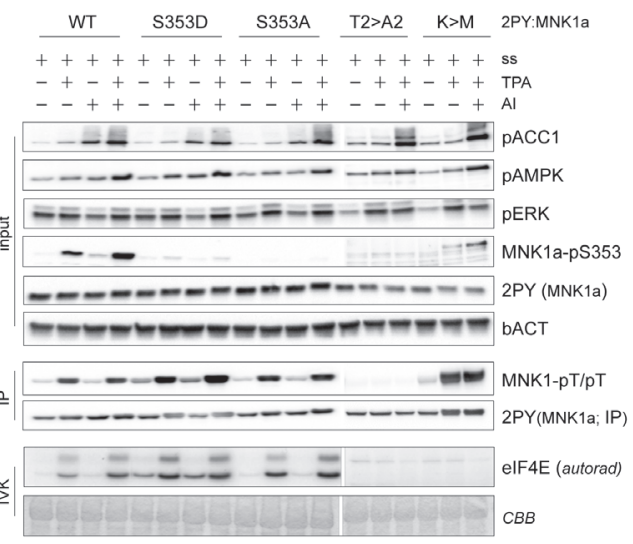

B

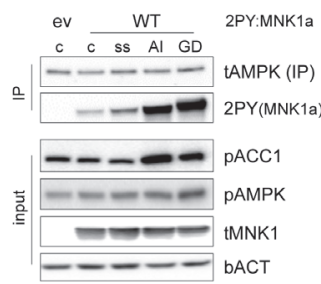

D

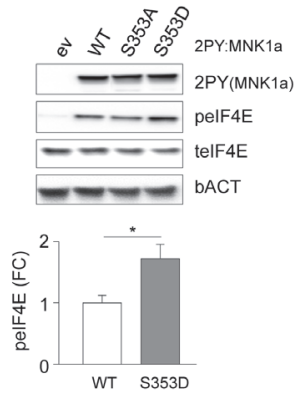

$\mathrm{F}$
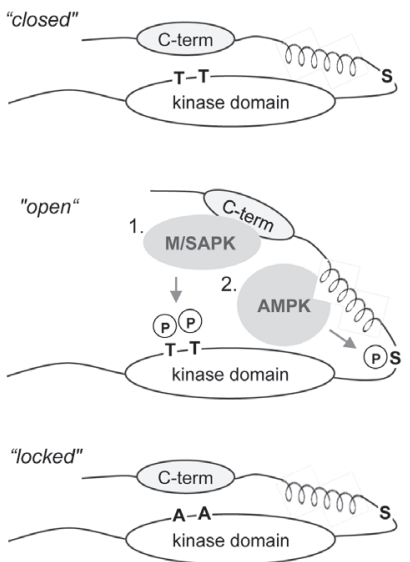

FIGURE 2. Metabolic stress-induced MNK1a-S353 phosphorylation enhances MNK1a kinase activity toward elF4E.

(A) $\mathrm{AMPK}^{\mathrm{WT}}$ and $\mathrm{AMPK}^{\mathrm{dNo}}$ MEFs expressing 2PY:MNK1 ${ }^{\mathrm{WT}}$ were treated with AICAR or A769662 as indicated. IB analyses of total cell extracts using the indicated antisera.

(B) U-2OS cells expressing 2PY:MNK1a ${ }^{\mathrm{WT}}$; (control: empty vector, ev), were treated as indicated: c, ss, Al (cf. Fig. 1G) or GD: glucose deprived). IB analyses of IP-ed and input material using the indicated antisera; $\beta$ Actin (bACT): loading control.

(C) U-2OS cells expressing 2PY:MNK1a ${ }^{\mathrm{WT}}$ were glucose deprived (GD; indicated in hrs); ${ }^{*}$ cells were glucose deprived, glucose was re-administered for $1 \mathrm{hr}$.

(D) U-2OS cells expressing 2PY:MNK1a ${ }^{\mathrm{WT}}$, 2PY:MNK1 $\mathrm{a}^{\mathrm{S} 353 \mathrm{~A}}$ or 2PY:MNK1a ${ }^{5353 \mathrm{D}}$ (control: empty vector, ev). IB analyses using the indicated antisera; $\beta A c t i n(b A C T)$ : loading control; (lower panel) quantitation pelF4E (FC: fold change) in U-2OS cells expressing 2 PY:MNK1a ${ }^{W T}$ or 2 PY:MNK1a ${ }^{53530}(n=5, * p<0.005)$. (E) U-2OS cells expressing 2PY-tagged MNK1a ${ }^{\mathrm{WT}}, \mathrm{MNK1} \mathrm{a}^{\mathrm{S} 353 \mathrm{~A}}, \mathrm{MNK1} \mathrm{a}^{\mathrm{S} 353 \mathrm{D}}, \mathrm{MNK}^{\mathrm{N}} \mathrm{a}^{\mathrm{T} 2 \mathrm{A2}}$ (a double T209A/T214A mutant) or MNK1 $\mathrm{a}^{\mathrm{K}>\mathrm{M}}$ (a kinase dead K78M mutant) were treated as indicated; AICAR, TPA or combination treatment (all preceded by ss). 2PY:MNK1a was IP-ed using PY antiserum (middle 
panels). IB analyses of IP-ed and input material using indicated antisera. IPs were used in IVKs with recombinant GST:eIF4E and [ ${ }^{-32}{ }^{32}$ ]ATP. White bars between sections indicate separate blots. Lower panels; pelF4E: autoradiograph; CBB image: loading control.

(F) A functional role for pS353 in MNK1a activation based on a previously suggested conformational change model (21): Inactive MNK1a is maintained in a 'closed' conformation (upper schematic). ERK and P38 (M/SAPK) binding of the MNK1a C-terminal binding domain (C-term) and subsequent M/ SAPK-mediated phosphorylation (encircled 'P's) at MNK1a-T209/T214 (bold 'TT') renders MNK1a receptive to AMPK-dependent phosphorylation at S353 (bold ' $\mathbf{S}$ '). In the context of metabolic stress, AMPK-mediated MNK1a-S353 phosphorylation stabilizes an active 'open' conformation. Replacement of T209/T214 by two non-phosphorylatable alanine residues (bold 'AA') desensitizes MNK1a to M/ SAPK signaling ('locked' state).

allows separation of upstream signaling events. AICAR treatment, alone or in combination with TPA (M/SAPK activator), consistently and highly induced PACC1, whereas TPA treatment alone only modestly induced pACC1 (Fig. 2E). TPA, with or without AICAR, massively increased MNK1-pT209/pT214 (MNK1a-pTpT) (Fig. 2E); these observations are in good agreement with reported upstream signaling events connecting M/SAPKs to MNK1a (22). Combination treatment with TPA and AICAR resulted in increased MNK1apS353, but only in the case of MNK1a ${ }^{\mathrm{WT}}$ and MNK1 ${ }^{\mathrm{K}>\mathrm{M}}$. Reduced S353 phosphorylation in U-2OS MNK1 $\mathrm{a}^{\mathrm{K}>\mathrm{M}}$ cells may be explained by consistently lower expression of the MNK1 ${ }^{K>M}$ mutant (Fig. 2E). As expected, the T209A/T214A (MNK1a ${ }^{T 2>A 2}$ ) mutant was no longer phosphorylated at the mutated phospho-sites, and neither IP-ed MNK1a ${ }^{\mathrm{T} 2>\mathrm{A} 2}$ nor MNK1 ${ }^{\mathrm{K}>\mathrm{M}}$ (K78M; kinase dead) mutant kinases phosphorylated elF4E (Fig. 2E). Remarkably, MNK1 $\mathrm{a}^{\mathrm{T} 2>\mathrm{A} 2}$ was no longer phosphorylated at S353, whereas, conversely, S353 mutation ( $>$ A or $S>D$ ) did not block the ability of T209/T214 to become phosphorylated (Fig. 2E). IP-ed MNK1a ${ }^{\mathrm{WT}}$ from AICAR only-treated cells lead to only marginally increased peIF4E, in support of the need for regulatory co-signaling by $M$ / SAPKs (Fig. 2E). In contrast, and in good agreement with the observations above (cf. Fig. 2D), MNK1a ${ }^{5353 D}$ consistently displayed enhanced pelF4E under AICAR or TPA onlytreated conditions; moreover, elF4E phosphorylation by MNK1a ${ }^{\mathrm{S} 353 \mathrm{D}}$ was already enhanced under non-stimulated conditions (Fig. 2E). Of note; pACC1 was not altered by MNK1a mutation. The combined data suggest that MNK1a selectively acts in the signaling downstream of AMPK leading to increased eIF4E phosphorylation, and points toward a hierarchical order of regulatory events within MNK1a: M/SAPK-mediated MNK1a-T209/ T214 phosphorylation precedes AMPK-dependent MNK1a-S353 phosphorylation.

\section{Discussion}

In this study we report that MNK1a is a direct AMPK target. We provide biochemical and genetic evidence that MNK1a-S353 is phosphorylated in vitro and in vivo in an AMPK-dependent manner and that AMPK and MNK1a physically interact. Finally, we show that MNK1a-pS353 correlates with increased elF4E phosphorylation in vitro and in 
vivo.

Members of the MAPK-activated protein kinases (MK) family fulfill multiple biological roles in cellular responses to extracellular cues (e.g. mitogenic stimulation, cellular stress). MNK1a, like other MAPKAPKs, is tightly regulated by M/SAPKs, among which ERK and P38 (32,33). The most well-characterized biochemical connection in regards to MNK1 is elF4E-S209 phosphorylation (24), although the exact relevance of MNK1mediated elF4E phosphorylation remains unclear (34). MNK1a mutation appears to affect phosphorylation of elF4E, not of ACC1, suggesting a selective role for MNK1a as a signaling intermediate in the regulation of protein synthesis, downstream of AMPK.

Based on a previously proposed regulatory model of MNK1a, our data suggest a physiological role for S353 phosphorylation in regulating MNK1a activity. MNK1a is activated upon T-loop phosphorylation, but also undergoes a conformational change to a more 'open' structure (21). Our MNK1a mutant analysis indicating that T209/T214 phosphorylation is a prerequisite for S353 phosphorylation appears congruent with this phospho-event being dependent on conformational change. Interestingly, an $\alpha$-helical structure from the first part of the unique MNK1a C-terminal region was predicted to suppress basal T-loop phosphorylation and activity (21); S353 is located at the start of this region. Based on existing and current data, we propose a functional extension to the MNK1a activation model: T-loop phosphorylation by canonical M/SAPK pathway activity precedes AMPK-mediated phosphorylation of MNK1a at S353 (Fig. 2F).

Our observations suggest that MNK1a-S353 phosphorylation by AMPK is not required for MNK1a activation per se, but affects and/or possibly directs kinase activity, upon a conformational change induced by M/SAPK. MNK1-pS353 may serve to fine-tune MNK1/ elF4E-mediated protein synthesis (mRNA translation) via AMPK. This finding has potential therapeutic implications for chronic or acute human conditions, including metabolic syndrome-associated disorders and cancer. Abnormal regulation of protein synthesis is known to drive tumor cell proliferation and survival. Importantly, both AMPK and MNK1a have been independently put forward as potential druggable targets $(35,36)$.

\section{Experimental procedures}

Expression vectors-For bacterial expression of MNK1a protein, glutathione S-transferase-tagged (GST)-MNK1a (pGEX-6P1) was kindly provided by C.G.Proud (Southampton, UK) (21). Active, hexahistidine-tagged (6His) AMPK was produced using a single hexacistronic expression vector encoding three AMPK and three LKB1 subunits as described (5). Expression of kinase-dead (KD) AMPK $\alpha 1^{\mathrm{D} 157 \mathrm{~A}}$ mutant was described earlier (37). Point mutations were introduced using QuickChange (Agilent). To generate eukaryotic expression vector, MNK1a cDNAs were subcloned in frame with an $\mathrm{N}$-terminal double polyoma 
(2PY)-tag into the BamHI and Sall sites of a retroviral pBabe vector (38); Amphotropic retrovirus was produced as described (39); transduced U-2OS and MEF cells were selected in medium containing $4 \mu \mathrm{g} / \mathrm{ml}$ puromycin.

Recombinant protein purification and cell-free kinase assays-Proteins were expressed in Rosetta 2 (DE3) E. coli cells (Merck Millipore, Germany) as described (5). 6His:AMPK and GST:MNK1a protein were purified using nickel-sepharose HP (GE Healthcare) and glutathione sepharose 4B (GE Healthcare), respectively. AMPK protein was eluted in elution buffer (50 mM NaH${ }_{2} \mathrm{PO}_{4^{\prime}}, 30 \%$ Glycerol, $0.5 \mathrm{M}$ sucrose, $250 \mathrm{mM}$ imidazole, $\mathrm{pH}$ 8) MNK1 a protein was eluted with freshly prepared buffer (Tris- $\mathrm{HCl} 50 \mathrm{mM}, 10 \mathrm{mM}$ reduced glutathione, $\mathrm{pH}$ 8).

Aliquots of resin-bound MNK1a protein $(10 \mu \mathrm{g})$ were incubated in $50 \mu \mathrm{l}$ kinase buffer (50 $\mathrm{mM}$ Hepes pH7.4, 5 mM MgCl, 0.04 mM AMP, 1 mM DTT, $200 \mu \mathrm{M}$ ATP) with 1 ug active AMPK protein and $4 \mu \mathrm{Ci}\left[\mathrm{Y}^{-32} \mathrm{P}\right] \mathrm{ATP}$ for $15 \mathrm{~min}$ at $37^{\circ} \mathrm{C}$. Beads were collected by centrifugation ( $5 \mathrm{~min}, 800 \mathrm{~g}$ ), washed and suspended in cleavage buffer (50 mM Hepes, $\mathrm{pH}$ 7.5, $150 \mathrm{mM} \mathrm{NaCl}, 0.5 \mathrm{mM}$ EDTA, $1 \mathrm{mM}$ DTT). For proteolytic removal of GST tags, resin-bound protein was incubated with PreScission protease (GE healthcare, UK) for 4 hrs at $4^{\circ} \mathrm{C}$ with constant mixing. Beads were pelleted (5 min, $800 \mathrm{~g}$ ); supernatant was transferred to a fresh tube. Samples were heated in SDS/PAGE sample buffer ( $5 \mathrm{~min}$, $95^{\circ} \mathrm{C}$ ). Samples were analyzed by SDS/PAGE ( $9 \%$ gels) electrophoresis followed by Coomassie Brilliant Blue (CBB) staining and/or autoradiography.

Mass spectrometry-GST:MNK1a and AMPK proteins were incubated with or without ATP in vitro as described above. Samples were separated by SDS-PAGE; MNK1a bands were excised and in-gel digested as described (40). Extracted tryptic peptides were desalted using homemade $\mathrm{C} 18$ columns, resuspended in $10 \%$ formic acid and analyzed by reversed phase nanoLC-MS/MS (Ultimate 3000 and Orbitrap Elite; Thermo Scientific). Peptides were trapped on a precolumn for $10 \mathrm{~min}$ (Acclaim PepMap100, C18, $5 \mu \mathrm{m}, 100 \AA$, 300 $\mu \mathrm{m}$ i.d. $\times 5 \mathrm{~mm}$, Thermo Scientific) in Buffer $A(0.1 \%$ formic acid in water) and separated on an analytical column (Acclaim PepMap100, C18, $5 \mu \mathrm{m}, 100 \AA, 75 \mu \mathrm{m}$ i.d. x $25 \mathrm{~cm}$ ) using a 70 min gradient (0-10 min: $5 \%$ buffer $B$ ( $80 \%$ acetonitrile, $0.1 \%$ formic acid), 10 $45 \mathrm{~min}$ : 10-45\% buffer B, 45-47 min: 45-99\% buffer B; 47-53 min 99\% buffer B; 53-70 min $5 \%$ buffer B) at $250 \mathrm{nl} / \mathrm{min}$. The mass spectrometer was operated in data-dependent mode with a 20s dynamic exclusion range. Full-scan MS spectra were acquired in the Orbitrap (range: m/z 350 to 1500) with a resolution of 120000 and an AGC of 1E6 ions. CID fragmentation in the ion trap was performed on the top 5 precursors of each full scan employing a collision energy of $35 \%$. Analysis of raw data was done by using MaxQuant (version 1.4.1.2 (41). The spectra were searched against the human SwissProt database version 06/2014 using the Andromeda search engine using default mass 
tolerance settings (42). Trypsin was set as the protease (two missed cleavages allowed). Fixed modification: Carbamidomethylation (Cys), variable modifications: Oxidation (Met), Phosphorylation (Ser, Thr, Tyr) and N-terminal protein acetylation. False discovery rate was set to 0.01 for peptides, proteins and modification sites. The minimum peptide score for modified peptides was set to 40 , the minimum peptide length was seven amino acids (aa).

Cell culture, Chemicals and Antibodies-Human osteosarcoma U2-OS cells (U2OS) and immortal mouse embryo fibroblasts (AMPK ${ }^{\mathrm{WT}}$ and $\mathrm{AMPK}^{\mathrm{dKO}}$ MEFs; (43) were cultured in DMEM (25 mM glucose; Gibco), supplemented with $10 \%$ (v/v) heat-inactivated fetal calf serum (iFCS, Bodinco BV, Alkmaar, The Netherlands) and penicillin/streptomycin (Invitrogen). Cellular AMPK activation was achieved with 5-Aminoimidazole-4carboxamide ribonucleotide (AICAR; 1.5 mM; Sigma) or A769662 (100 $\mu \mathrm{M}$; Tocris Biosciences, UK) for 45-60 min following 16 hrs serum starvation (ss; DMEM, 25 mM glucose). For M/SAPK activation, TPA $(100 \mu \mathrm{M})$ was used following ss. For glucose deprivation (GD), DMEM medium without glucose (Gibco) was used. Antibodies used: (total) tMNK1a (\#2195), pMNK1(T209/T214, \#2111), AMPK-pT172 (\#2535), AMPK (\#2532), elF4E-pS209 (\#9741) and pERK (\#9101; Cell Signaling Technology); pACC (\#07303; Merck Millipore); BActin (bACT, \#0869100; MP Biomedicals); elF4E (\#610269; BD Biosciences). Rabbit polyclonal MNK1a Ser353 phosphorylation-specific antibodies were custom-ordered (Genosphere Biotech Paris, France).

Immunoprecipitation and immunoblotting-Cells were lysed in mild lysis buffer ( $250 \mathrm{mM}$ $\mathrm{NaCl}, 0.1 \%$ Igepal (NP40), $5 \mathrm{mM}$ EDTA, $50 \mathrm{mM}$ HEPES pH 7.0) supplemented with $5 \mathrm{mM}$ benzamidine, $5 \mu \mathrm{g} / \mathrm{ml}$ antipain, $5 \mu \mathrm{g} / \mathrm{ml}$ leupeptin, $5 \mu \mathrm{g} / \mathrm{ml}$ aprotinin, $1 \mathrm{mM}$ sodium vanadate, $10 \mathrm{mM}$ sodium fluoride, $10 \mathrm{mM}$ pyrophosphate, $10 \mathrm{mM} \beta$-glycerophosphoate, $0.5 \mathrm{mM}$ DTT and $1 \mathrm{mM}$ PMSF. Extracts were sonicated on ice and centrifugated; $3 \%$ of the supernatant was stored as input $\left(-80^{\circ} \mathrm{C}\right)$. Endogenous AMPK was IP-ed using a mix of AMPK $\alpha 1$ and AMPK $\alpha 2$ antibodies (sheep polyclonal; kindly provided by D. G. Hardie, Dundee, UK); 2PY-tagged MNK1a (2PY:MNK1a) was IP-ed using PY antiserum (Covance, USA). For IP, $500 \mu \mathrm{g}$ of protein lysate was incubated with primary antibody under constant mixing at $4^{\circ} \mathrm{C}$ overnight, followed by incubation with Protein $\mathrm{G}$ sepharose beads ( $4 \mathrm{hrs}, 4^{\circ} \mathrm{C}$ ). Immune-complexes were collected by centrifugation and analyzed by immunoblotting as described (5). Signals were detected using enhanced chemoluminescence (ECL; Pierce). Band intensities were quantitated with Quantity One software (Bio-Rad). Data was statistically analyzed by performing 2-tailed paired t-tests using Microsoft Excel.

elF4E kinase assay- $350 \mu \mathrm{g}$ U-2OS 2PY:MNK1a cell lysates were incubated with PY antibody $\left(2 \mathrm{hrs}, 4^{\circ} \mathrm{C}\right) ; 40 \mu \mathrm{l}$ Protein G slurry was added for 1.5 hours $\left(4^{\circ} \mathrm{C}\right)$. Beads were 
pelleted ( $5 \mathrm{~min}, 800 \mathrm{~g}$ ) and washed twice with mild lysis buffer, twice with $0.5 \mathrm{M} \mathrm{LiCl}$ and twice with kinase buffer as previously described (21). Beads were re-suspended in $50 \mu \mathrm{l}$ kinase buffer and incubated $\left(15 \mathrm{~min}, 37^{\circ} \mathrm{C}\right)$ with $1 \mu \mathrm{g}$ of recombinant GST: elF4E. The reaction was terminated by adding SDS-PAGE sample buffer $\left(5 \mathrm{~min}, 95^{\circ} \mathrm{C}\right)$. Samples were analyzed by SDS-PAGE (9\% gels) and autoradiography. $200 \mu \mathrm{g}$ Cell lysates were processed in parallel with IP antibody as controls.

\section{Acknowledgement}

We thank R. Stead (Southampton, UK) and members of the Molecular Genetics department (Maastricht University) for helpful comments and support.

\section{Conflict of interest}

The authors declare that they do not have a conflict of interest.

\section{Author contributions}

$X Z$, JWV and DN designed the study; XZ, VD, RT, CP, BV, JWV, DN contributed to data acquisition, analysis and interpretation; $X Z, J W V, D N$ drafted the manuscript; $X Z, V D, R T$, $\mathrm{CP}, \mathrm{BV}, \mathrm{JWV}$, DN provided final approval of the submitted version.

\section{Footnotes}

Current research in the laboratory of DN is funded by The Netherlands Organization for Scientific Research (NWO) (VIDI grant number 864.10.007). XZ is supported by the Chinese Scholarship Council. The Proteomics Facility (CP) is funded by the IZKF Aachen. 


\section{References}

1. Hardie, D. G., Ross, F. A., and Hawley, S. A. (2012) AMPK: a nutrient and energy sensor that maintains energy homeostasis. Nat Rev Mol Cell Biol 13, 251-262

2. Steinberg, G. R., and Kemp, B. E. (2009) AMPK in Health and Disease. Physiol Rev 89, 1025-1078

3. Stein, S. C., Woods, A., Jones, N. A., Davison, M. D., and Carling, D. (2000) The regulation of AMP-activated protein kinase by phosphorylation. Biochem J 345 Pt 3, 437-443

4. Woods, A., Vertommen, D., Neumann, D., Turk, R., Bayliss, J., Schlattner, U., Wallimann, T., Carling, D., and Rider, M. H. (2003) Identification of phosphorylation sites in AMP-activated protein kinase (AMPK) for upstream AMPK kinases and study of their roles by site-directed mutagenesis. J Biol Chem 278, 28434-28442

5. Oligschlaeger, Y., Miglianico, M., Chanda, D., Scholz, R., Thali, R. F., Tuerk, R., Stapleton, D. I., Gooley, P. R., and Neumann, D. (2015) The recruitment of AMP-activated protein kinase to glycogen is regulated by autophosphorylation. $J$ Biol Chem 290, 11715-11728

6. Viollet, B., Foretz, M., and Schlattner, U. (2014) Bypassing AMPK phosphorylation. Chem Biol 21, 567-569

7. Dasgupta, B., and Chhipa, R. R. (2016) Evolving Lessons on the Complex Role of AMPK in Normal Physiology and Cancer. Trends Pharmacol Sci 37, 192-206

8. Li, W., Saud, S. M., Young, M. R., Chen, G., and Hua, B. (2015) Targeting AMPK for cancer prevention and treatment. Oncotarget 6, 73657378

9. Mihaylova, M. M., and Shaw, R. J. (2011) The AMPK signalling pathway coordinates cell growth, autophagy and metabolism. Nat Cell Biol 13, 1016-1023

10. Munday, M. R. (2002) Regulation of mammalian acetyl-CoA carboxylase. Biochem Soc Trans 30, 1059-1064

11. Gwinn, D. M., Shackelford, D. B., Egan, D. F., Mihaylova, M. M., Mery, A., Vasquez, D. S., Turk, B. E., and Shaw, R. J. (2008) AMPK phosphorylation of raptor mediates a metabolic checkpoint. Mol Cell 30, 214-226

12. Huang, J., and Manning, B. D. (2008) The TSC1TSC2 complex: a molecular switchboard controlling cell growth. Biochem J 412, 179-190

13. Ducommun, S., Deak, M., Sumpton, D., Ford, R. J., Nunez Galindo, A., Kussmann, M., Viollet, B., Steinberg, G. R., Foretz, M., Dayon, L., Morrice, N. A., and Sakamoto, K. (2015) Motif affinity and mass spectrometry proteomic approach for the discovery of cellular AMPK targets: identification of mitochondrial fission factor as a new AMPK substrate. Cell Signal 27, 978-988

14. Thali, R. F., Tuerk, R. D., Scholz, R., Yoho-Auchli, Y., Brunisholz, R. A., and Neumann, D. (2010) Novel candidate substrates of AMP-activated protein kinase identified in red blood cell lysates. Biochem Biophys Res Commun 398 296-301

15. Tuerk, R. D., Thali, R. F., Auchli, Y., Rechsteiner, H., Brunisholz, R. A., Schlattner, U., Wallimann, T., and Neumann, D. (2007) New candidate targets of AMP-Activated protein kinase in murine brain revealed by a novel multidimensional substrate-screen for protein kinases. J Proteome Res 6, 3266-3277

16. Banko, M. R., Allen, J. J., Schaffer, B. E., Wilker, E. W., Tsou, P., White, J. L., Villen, J., Wang, B., Kim, S. R., Sakamoto, K., Gygi, S. P., Cantley, L. C., Yaffe, M. B., Shokat, K. M., and Brunet, A. (2011) Chemical genetic screen for AMPKalpha2 substrates uncovers a network of proteins involved in mitosis. Mol Cell 44, 878-892

17. Moreno, D., Viana, R., and Sanz, P. (2009) Twohybrid analysis identifies PSMD11, a nonATPase subunit of the proteasome, as a nove interaction partner of AMP-activated protein kinase. Int J Biochem Cell Biol 41, 2431-2439

18. Mok, J., Im, H., and Snyder, M. (2009) Global identification of protein kinase substrates by protein microarray analysis. Nat Protoc 4, 18201827

19. Thali, R. F. (2010) Exploring the Target Spectrum of AMP-activated protein kinase, Diss. ETH no. 18981,, Zürich, Switzerland

20. Hou, J., Lam, F., Proud, C., and Wang, S. (2012) Targeting Mnks for cancer therapy. Oncotarget 3, 118-131

21. Goto, S., Yao, Z., and Proud, C. G. (2009) The C-terminal domain of Mnk1a plays a dual role in tightly regulating its activity. Biochem J 423, 279-290

22. Waskiewicz, A. J., Flynn, A., Proud, C. G., and Cooper, J. A. (1997) Mitogen-activated protein kinases activate the serine/threonine kinases Mnk1 and Mnk2. Embo J 16, 1909-1920

23. Waskiewicz, A. J., Johnson, J. C., Penn, B., Mahalingam, M., Kimball, S. R., and Cooper, J. A. (1999) Phosphorylation of the cap-binding protein eukaryotic translation initiation factor $4 \mathrm{E}$ by protein kinase Mnk1 in vivo. $\mathrm{Mol}$ Cell Biol 19, $1871-1880$ 
24. Wang, X., Flynn, A., Waskiewicz, A. J., Webb, B. L., Vries, R. G., Baines, I. A., Cooper, J. A., and Proud, C. G. (1998) The phosphorylation of eukaryotic initiation factor elF4E in response to phorbol esters, cell stresses, and cytokines is mediated by distinct MAP kinase pathways. J Biol Chem 273, 9373-9377

25. Pyronnet, S., Imataka, H., Gingras, A. C., Fukunaga, R., Hunter, T., and Sonenberg, N. (1999) Human eukaryotic translation initiation factor 4G (elF4G) recruits mnk1 to phosphorylate elF4E. Embo J 18, 270-279

26. Bhat, M., Robichaud, N., Hulea, L., Sonenberg, N., Pelletier, J., and Topisirovic, I. (2015) Targeting the translation machinery in cancer. Nat Rev Drug Discov 14, 261-278

27. Siddiqui, N., and Sonenberg, N. (2015) Signalling to elF4E in cancer. Biochem Soc Trans 43, 763772

28. Klaus, A., Zorman, S., Berthier, A., Polge, C., Ramirez, S., Michelland, S., Seve, M., Vertommen, D., Rider, M., Lentze, N., Auerbach, D., and Schlattner, U. (2013) Glutathione S-transferases interact with AMP-activated protein kinase: evidence for S-glutathionylation and activation in vitro. PLoS One 8, e62497

29. Goransson, O., McBride, A., Hawley, S. A., Ross, F. A., Shpiro, N., Foretz, M., Viollet, B., Hardie, D. G., and Sakamoto, K. (2007) Mechanism of action of A-769662, a valuable tool for activation of AMP-activated protein kinase. J Biol Chem 282, 32549-32560

30. Guigas, B., Sakamoto, K., Taleux, N., Reyna, S. M., Musi, N., Viollet, B., and Hue, L. (2009) Beyond AICA riboside: in search of new specific AMP-activated protein kinase activators. IUBMB Life 61, 18-26

31. Lu, C., Makala, L., Wu, D., and Cai, Y. (2016) Targeting translation: elF4E as an emerging anticancer drug target. Expert Rev Mol Med 18, e2

32. Roux, P. P., and Blenis, J. (2004) ERK and p38 MAPK-activated protein kinases: a family of protein kinases with diverse biological functions. Microbiology and molecular biology reviews : MMBR 68, 320-344

33. Ueda, T., Watanabe-Fukunaga, R., Fukuyama, H., Nagata, S., and Fukunaga, R. (2004) Mnk2 and Mnk1 are essential for constitutive and inducible phosphorylation of eukaryotic initiation factor $4 \mathrm{E}$ but not for cell growth or development. Mol Cell Biol 24, 6539-6549

34. Joshi, S., and Platanias, L. C. (2014) Mnk kinase pathway: Cellular functions and biological outcomes. World J Biol Chem 5, 321-333

35. Hardie, D. G. (2013) AMPK: a target for drugs and natural products with effects on both diabetes and cancer. Diabetes 62, 2164-2172

36. Proud, C. G. (2015) Mnks, elF4E phosphorylation and cancer. Biochim Biophys Acta 1849, 766773

37. Neumann, D., Suter, M., Tuerk, R., Riek, U., and Wallimann, T. (2007) Co-expression of LKB1, MO25alpha and STRADalpha in bacteria yield the functional and active heterotrimeric complex. Mol Biotechnol 36, 220-231

38. Morgenstern, J. P., and Land, H. (1990) Advanced mammalian gene transfer: high titre retroviral vectors with multiple drug selection markers and a complementary helper-free packaging cell line. Nucleic Acids Res. 18, 35873596

39. Kinsella, T. M., and Nolan, G. P. (1996) Episomal vectors rapidly and stably produce high-titer recombinant retrovirus. Hum.Gene Ther. 7, 1405-1413

40. von Kriegsheim, A., Preisinger, C., and Kolch, W. (2008) Mapping of signaling pathways by functional interaction proteomics. Methods Mol Biol 484, 177-192

41. Cox, J., and Mann, M. (2008) MaxQuant enables high peptide identification rates, individualized p.p.b.-range mass accuracies and proteomewide protein quantification. Nat Biotechnol 26, 1367-1372

42. Cox, J., Neuhauser, N., Michalski, A., Scheltema, R. A., Olsen, J. V., and Mann, M. (2011) Andromeda: a peptide search engine integrated into the MaxQuant environment. J Proteome Res 10, 1794-1805

43. Laderoute, K. R., Amin, K., Calaoagan, J. M., Knapp, M., Le, T., Orduna, J., Foretz, M., and Viollet, B. (2006) 5'-AMP-activated protein kinase (AMPK) is induced by low-oxygen and glucose deprivation conditions found in solidtumor microenvironments. Mol Cell Biol 26, 5336-5347

44. 

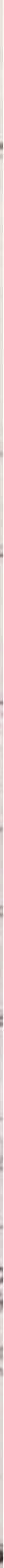

क्त

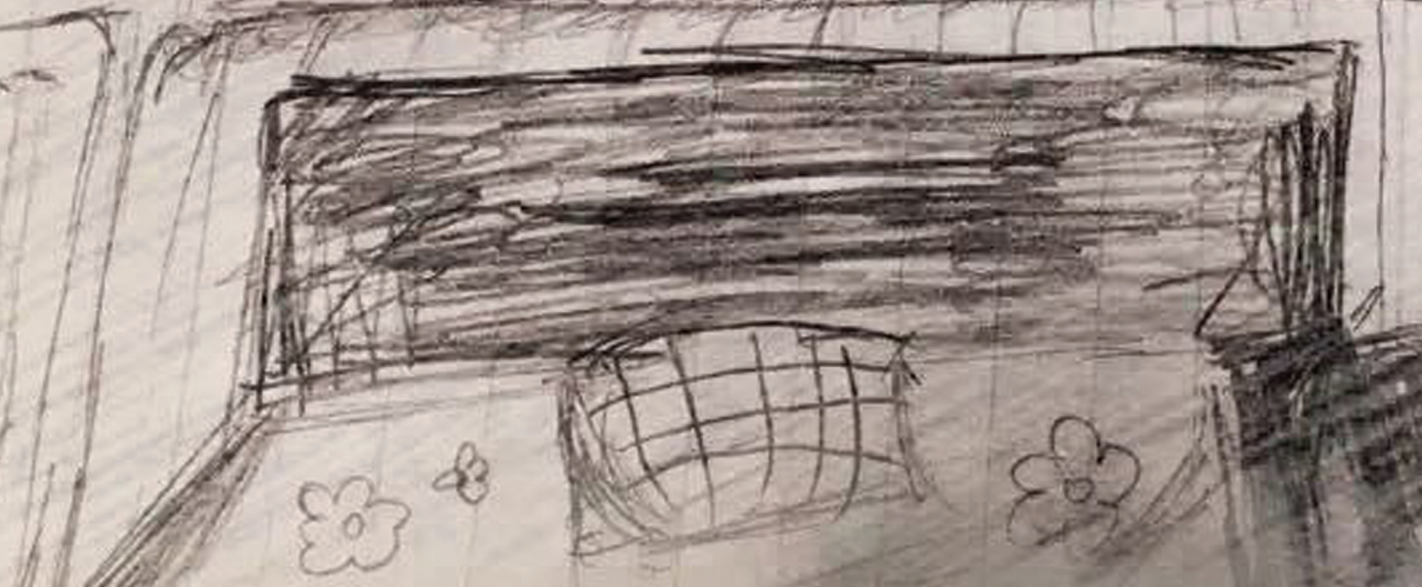




\section{Chapter 4}

\section{AMPK and ERK control MNK1a-mediated elF4E phosphorylation in cell survival}

Xiaoqing Zhu ${ }^{1}$, Vivian Dahlmans ${ }^{2}$, J. Willem Voncken ${ }^{2 \#}$, Dietbert Neumann ${ }^{1 \#}$

${ }^{1}$ Dept. of Molecular Genetics, CARIM School of Cardiovascular Diseases;

${ }^{2}$ Dept. of Molecular Genetics, Maastricht University Medical Center, Maastricht,

The Netherlands.

"These authors contributed equally 


\begin{abstract}
Protein translation is a tightly regulated process as it is crucially involved in many biological processes including cell proliferation and survival. The MAP kinaseinteracting serine/threonine kinases 1 and 2 (MNK1/2) phosphorylate eukaryotic translation initiation factor 4E (eIF4E), but the functional significance of this event for protein translation is incompletely understood. Recently, MNK1/2 have emerged as cancer therapy targets, partly motivated by the observed upregulation of elF4E phosphorylation in various tumors. We have previously shown that AMPK-dependent phosphorylation of the splice isoform MNK1a at Serine 353 causes increased cellular phosphorylation of elF4E. Here we report that this phosphorylation may act as a protective process on cell growth/survival under stress. At the molecular level, MNK1 is a stable AMPK binding partner in which complex ERK is also a player and the functional regulation of AMPK-MNK1 is tightly regulated by both its C-terminus and ERK. These findings uncover a novel effect of AMPK-MNK1 axis as a mediator for cell growth adaptation to energy stress.
\end{abstract}

Keywords: AMP-activated protein kinase (AMPK), MAP kinase interacting serine/ threonine kinase 1 (MNK1), phosphorylation, interaction, translation, cell growth/ survival 


\section{Introduction}

Protein synthesis, or mRNA translation, is vital for cell proliferation and survival (1). Compared with gene expression, it mediates faster cellular responses to microenvironmental changes, e.g. starvation and growth factors, and thus also plays decisive roles in metabolism $(1,2)$. The overall status of protein synthesis in cells is tightly controlled by translation initiation complexes, among which the eukaryotic initiation factor $4 \mathrm{E}$ (elF4E) is a rate-limiting factor that binds $\mathrm{m7G} 5$ 'cap-structures of mRNAs $(1,3,4)$. MAP kinase-interacting serine/threonine kinase 1 and 2 (MNK1/2) phosphorylate eIF4E (5), but it has remained unclear how it affects elF4E function. In line with the observed elF4E overexpression and high level of phosphorylation in various tumors (6), inhibition of MNK1/2 was shown to reduce cell proliferation and induce apoptosis in breast and prostate cancer cells (7-10). In sharp contrast, however, MNK1/2 are found to be dispensable for normal cell growth and development, though with essential roles in elF4E phosphorylation $(11,12)$.

MNK1/2 are downstream targets of a number of kinases, among which extracellularsignaling regulated kinases (ERK) and the related P38 stress activated kinase (5,13-15). In response to both mitogens and cellular stress, MNK1/2 are activated by phosphorylation of two conserved threonine residues in the activation loop (MNK1: T209 and T214; MNK2: T244 and T249) (3,5). Activated MNK1/2 phosphorylates elF4E at serine 209, which may change its affinity to the mRNA 5 'cap-structure $(5,13,16)$. The two human genes MKNK1 and MKNK2 by alternative splicing give rise to two protein variants for each: MNK1a, MNK1b and MNK2a, MNK2b, respectively (17). All four MNK isoforms carry a common nuclear localization signal (NLS) and elF4G protein binding site at their $\mathrm{N}$-termini (4). More marked differences are found in their C-terminal regions (18), such as a MAPK-binding site in MNK1a and MNK2a that is absent in MNK1b and MNK2b (3). Therefore, the $b$-isoforms are not substrates of ERK and P38; thus, their high basal kinase activity toward elF4E correlates with lack of regulatory control by M/SAPKs (mitogen/ stress activated protein kinases) (18-20). MNK2a requires low level of ERK/P38 activity for attaining high basal kinase activity, while MNK1a shows low basal activity that is highly increasing upon phosphorylation by ERK/P38 (16). Therefore, MNK1a may be essential for increased eIF4E phosphorylation in response to stress.

The function of elF4E is also regulated by the mammalian target of rapamycin (mTOR) signaling pathway via control of elF4E-binding proteins (4EBPs) (21). Binding of 4E-BP to elF4E is inhibitory to its action, which can be released by mTOR-dependent phosphorylation of $4 \mathrm{E}-\mathrm{BP}$ (22). mTOR is predominantly involved in global protein translation regulation and thus cell proliferation control upon various stimuli $(23,24)$. As a metabolic checkpoint for cell growth, AMPK directly phosphorylates both tumor 
suppressor tuberous sclerosis complex 2 (TSC2) (25) and regulatory associated protein of mTOR (Raptor) (26), thereby inhibiting mTOR complex 1 (mTORC1) kinase activity and reducing translational rate (27). Inhibitors of $\mathrm{mTOR}$, such as rapamycin, have been approved for treatment of various cancers $(28,29)$. However, elF4E phosphorylation appears to be independent of the mammalian target of rapamycin (mTOR) signaling pathway, since 4E-BPs still bind to phosphorylated elF4E (30).

We previously found that AMPK-mediated MNK1 serine 353 (S353) phosphorylation increases its kinase activity toward elF4E phosphorylation, indicating a novel and direct role of AMPK that may be expected to augment translation (31). Thus, the AMPK-MNK1 axis would be opposing to the well-established AMPK-mTOR axis both regulating protein translation but in different ways. Here we show that AMPK-mediated MNK1 S353 phosphorylation increases sensitivity to the rapamycin-induced inhibitory effect on cell growth, while it promotes cell survival upon stress probably via stress-related translation augmentation. Given the effect of S353D on cell growth control, we further explored the regulation mechanism on both physical and functional interaction of AMPK-MNK1 under stress condition. We find that physical interaction of AMPK-MNK1 is neither dependent on the $\mathrm{N}$ - and C-terminal MNK1 domains nor its kinase activity, and that the MAPKbinding domain at the C-terminal region of MNK1 regulates AMPK-mediated MNK1 S353 phosphorylation. Moreover, ERK seems to be both structurally and functionally involved in the regulation of AMPK-MNK1 complex.

\section{Material and Methods}

Expression vectors-MNK1a cDNAs were subcloned in frame with an N-terminal double polyoma (2PY)-tag into the BamHI and Sall sites of a retroviral pBabe vector as described $(31,32)$; site-directed mutagenesis was performed by using QuickChange (Agilent). Amphotropic retroviruses were produced as described (33); transduced cells were selected in medium with $4 \mathrm{\mu g} / \mathrm{ml}$ puromycin.

Cell culture, chemicals and treatment-Human osteosarcoma U-2OS cells (U-2OS) were cultured in DMEM (25 mM glucose; Gibco), supplemented with $10 \%$ (v/v) heatinactivated fetal calf serum (iFCS, Bodinco BV, Alkmaar, The Netherlands) and penicillin/ streptomycin (Invitrogen). For glucose deprivation (GD), DMEM medium without glucose (Gibco) was used for different time points as indicated. Replenishment of glucose was achieved by adding normal growth medium back for 1 hour. Medium with various glucose concentrations were used in cell growth measurement. Rapamycin (various concentrations as indicated) were used as treatment for 1 hour or as indicated in growth curves. MEK inhibitor (U0126; $10 \mu \mathrm{M}$ ) and p38 inhibitor (SB202190; $20 \mu \mathrm{M}$ ) were applied along with glucose deprivation. 
Immunoprecipitation and immunoblotting-Cells were lysed in mild lysis buffer ( $250 \mathrm{mM}$ $\mathrm{NaCl}, 0.1 \%$ Igepal (NP40), $5 \mathrm{mM}$ EDTA, $50 \mathrm{mM}$ HEPES pH 7.0) supplemented with $5 \mathrm{mM}$ benzamidine, $5 \mu \mathrm{g} / \mathrm{ml}$ antipain, $5 \mu \mathrm{g} / \mathrm{ml}$ leupeptin, $5 \mu \mathrm{g} / \mathrm{ml}$ aprotinin, $1 \mathrm{mM}$ sodium vanadate, $10 \mathrm{mM}$ sodium fluoride, $10 \mathrm{mM}$ pyrophosphate, $10 \mathrm{mM} \beta$-glycerophosphoate, $0.5 \mathrm{mM}$ DTT and $1 \mathrm{mM}$ PMSF. Extracts were sonicated on ice and centrifuged; $3 \%$ of the supernatant was stored as input $\left(-80^{\circ} \mathrm{C}\right)$. Endogenous AMPK was IP-ed using a mix of AMPK $\alpha 1$ and AMPK $\alpha 2$ antibodies (sheep polyclonal; kindly provided by D. G. Hardie, Dundee, UK); 2PY-tagged MNK1a was IP-ed using PY antiserum (Covance, USA). For IP, $500 \mu \mathrm{g}$ of protein lysate was incubated with primary antibody under constant mixing at $4^{\circ} \mathrm{C}$ overnight, followed by incubation with Protein $\mathrm{G}$ sepharose beads ( $4 \mathrm{hrs}, 4^{\circ} \mathrm{C}$ ). Immune-complexes were collected by centrifugation and analyzed by immunoblotting as described (5). Antibodies used: (total) tMNK1a (\#2195), pMNK1 (T209/T214, \#2111), AMPK-pT172 (\#2535), AMPK (\#2532), elF4E-pS209 (\#9741), pERK (\#9101), tERK (\#9102), pP38 (\#9211), and P38 (\#9212; Cell Signaling Technology); pACC (\#07-303; Merck Millipore); $\beta$-Actin (bACT, \#0869100; MP Biomedicals); elF4E (\#610269; BD Biosciences). Rabbit polyclonal MNK1a Ser353 phosphorylation-specific antibodies were customordered (Genosphere Biotech Paris, France).

Cellular translational rate assay-a SOP-puromycin-labelling assay was developed based on the SUnSET method (34). Briefly, cells were exposed to puromycin for exactly 10 minutes and incubation was stopped by adding RIPA buffer for cell lysates after washing twice with $0.9 \% \mathrm{NaCl}$ solution. Samples were sonicated for lysing and DNA content measurement was done for normalization. The de novo synthesized polypeptides with puromycin labelling were quantified with dot-blot in combination of puromycin-antibody.

Cell proliferation assays-U-2OS cells expressing MNK1 WT/S>A/S>D mutants were plated in 24-multiwell plates. For glucose deprivation treatment, cells were washed $3 x$ with PBS and incubated with DMEM medium containing different glucose concentrations as indicated. For rapamycin treatment, cells were incubated with normal growth medium containing rapamycin at different concentrations as indicated and cells incubated with medium containing DMSO served as control. At each time points, cells were washed twice with PBS and fixed for 10 minutes with 3.7\% formaldehyde at room temperature. After fixation, cells were rinsed $6 x$ with demi water. Cells were then stained with $0.1 \%$ Crystal violet for 30 minutes and washed $5 x$ with demi water. Crystal violet was extracted with $10 \%$ acetic acid and absorbance was measured spectrophotometrically at $590 \mathrm{~nm}$. Statistical analysis-Bar/linear graph data are presented as means \pm SEM. Statistical analysis was performed by using student's $t$-test and statistical analysis software Prism 5 (GraphPad Software Inc.). A p-value $<0.05$ was considered statistically significant. 


\section{Results and Discussion}

MNK1 S353D mutant increases cellular elF4E phosphorylation upon GD, but not translational initiation

Previously, we have reported that AMPK-mediated MNK1a phosphorylation increases its kinase activity toward elF4E phosphorylation in vitro and in cells (basal level) (31). To determine its potential consequences for translation, we tracked the kinetics of eFI4E phosphorylation (pelF4E) under metabolic stress (glucose deprivation; GD) as a function of time. To this end, pelF4E levels were measured in the osteosarcoma cell line U-2OS cells, which express very low endogenous MNK1a, in which PY-tagged MNK1 WT

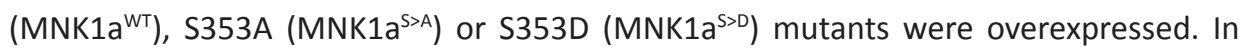
MNK1a ${ }^{\text {WT }}$ cells, pelF4E showed a multiphasic response, with an initial increase at $1 \mathrm{hr}$ post-GD and a subsequent peak induction at $4 \mathrm{hrs}$ post-GD, followed by a decline to base levels at 8-24 hrs post-GD (Figure 1A). This multiphasic response was paralleled by phosphorylation of acetyl-CoA carboxylase ( $\mathrm{PACC}$ ), a metabolic stress-related target of AMPK, in line with the reported biochemical connection of both targets to AMPK activation (Figure 1A) (31). As reported before, basal (i.e. non-GD) pelF4E levels were moderately elevated in MNK1 $\mathrm{a}^{\mathrm{S}>\mathrm{D}}$ cells (31). Although cells expressing mutant MNK1-S353 proteins displayed a comparable pACC profile in response to GD, both in the presence of either $M N K 1 a^{S>A}$ or $M N K 1 a^{S>D}$ the multiphasic pelF4E response was lost: whereas after an initial $1 \mathrm{hr}$ post-GD peak induction in both conditions, MNK1a ${ }^{\mathrm{S}>\mathrm{A}}$ cells showed a gradual decline of pelF4e to $24 \mathrm{hrs}$ post-GD, pelF4E levels were maintained at high levels in MNK1 ${ }^{\mathrm{S}>\mathrm{D}}$ cells. These observations are in line with our previous finding that S353 functionally links to regulation of pelF4E, but also suggests a general inability of MNK1a-S353 mutant proteins, and its down-stream target elF4E, to be properly controlled in the context of metabolic stress.

As these findings pointed to a potential effect of $M N K 1 a^{S>D}$ on regulation of mRNA translation, we next aimed to determine the effect of MNK1a-S353 mutation on translation. To this end we initiated measurements using a puromycin labelling assay, a technology that relies on incorporation and quantitative detection of puromycin into a nascent polypeptide chains (34-36). Our initial analyses focused on establishing differences at base line and under stressed conditions; for the latter we employed serum starvation (16 hrs) and mTOR inhibition by rapamycin (RAPA; $1 \mathrm{hr}$ ). Overexpression of MNK1 $1 \mathrm{a}^{\mathrm{WT}}$ showed a modest increase of detectable puromycin incorporation, which correlated well with increased pelF4E in U-2OS/MNK1aWT versus U-20S/ev (empty vector) cells (Figure 1B) (31). Serum starvation decreased, whereas RAPA increased general translational activity (Supplemental Figure 1); the latter was consistent with published findings that rapamycin induces translation initiation in a PI3K/MNK1a/elF4E 
A

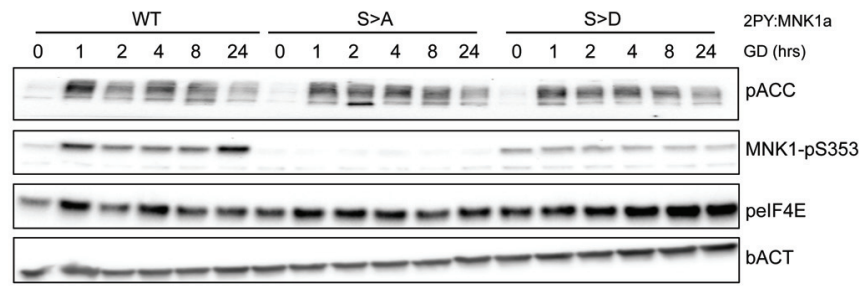

B

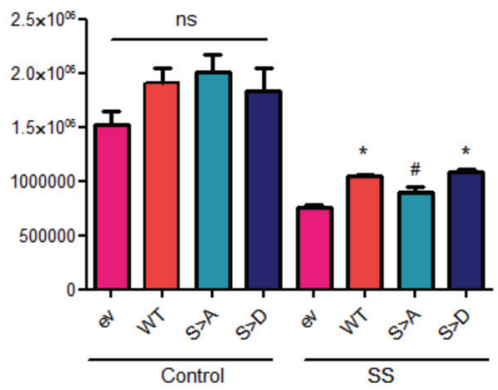

Figure 1. MNK1 $a^{S>D}$ maintains high elF4E phosphorylation under metabolic stress. (A) Time course experiment of glucose deprivation (GD) in U-2OS cells overexpressing MNK1a ${ }^{\mathrm{WT}}, \mathrm{MNK} 1 \mathrm{a}^{\mathrm{S}>\mathrm{A}}$ or MNK1 $\mathrm{a}^{\mathrm{S}>\mathrm{D}}$. Cell lysates were analyzed by immunoblotting with indicated antisera. (B) Translational rate was measured by puromycin labelling assay. Statistical test: Student's $t$-test ev vs. MNK1a WT/ S>A/S>D (ns: not significant; *: $p<0.05 ; \#: p=0.06)$.

dependent manner (15). These observations suggested that the methodology was suitable to measure differences in overall translation. However, under these conditions, no significant differences were observed between MNK1 ${ }^{W T}, M N K 1 a^{S>A}$ or MNK1 $a^{S>D}$ cells (Figure 1B). As we have established that S353 mutation does not compromise MNK1a's ability to induce elF4E phosphorylation, the short time span of the current experimental setting may have precluded detecting any differences in translation capacity. These data indicate that translational capacity should be measured at a time-point where pelF4E levels show the largest difference (e.g. 8 hrs post-GD); these experiments are ongoing.

MNK1-S353D increases sensitivity to rapamycin and allows higher proliferation under metabolic stress

In light of the importance of elF4E-mediated translational activity for cell proliferation and survival, we asked whether MNK1 ${ }^{\mathrm{WT}}$, MNK1 $\mathrm{a}^{\mathrm{S}>\mathrm{A}}$ or MNK1 $1 \mathrm{a}^{\mathrm{S}>\mathrm{D}}$ had an effect on U-2OS cell proliferation. Since cellular translation is co-regulated by multiple upstream signaling modules, including mTOR, cells were grown in the absence or presence of rapamycin to explore a possible interaction with the mTOR axis. Under control conditions ( 0 nM RAPA), overexpression of any form of MNK1a caused a general reduction of cell proliferation with no significant differences between the various MNK1a forms. In sharp contrast, at various rapamycin concentrations $(10 \mathrm{nM}-20 \mu \mathrm{M})$, the MNK1 $\mathrm{a}^{\mathrm{S}>\mathrm{D}}$ mutant expressing cells 


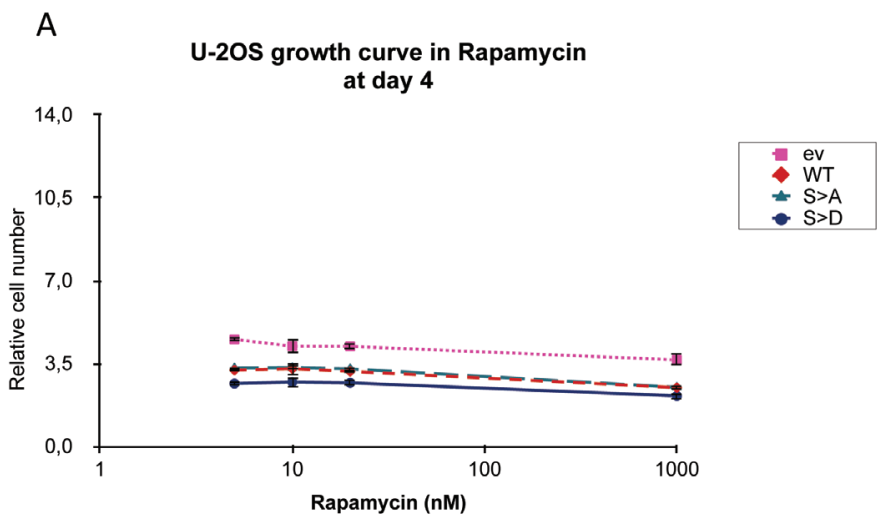

\section{B $U-20 S$ growth curve in low glucose medium at day 6}

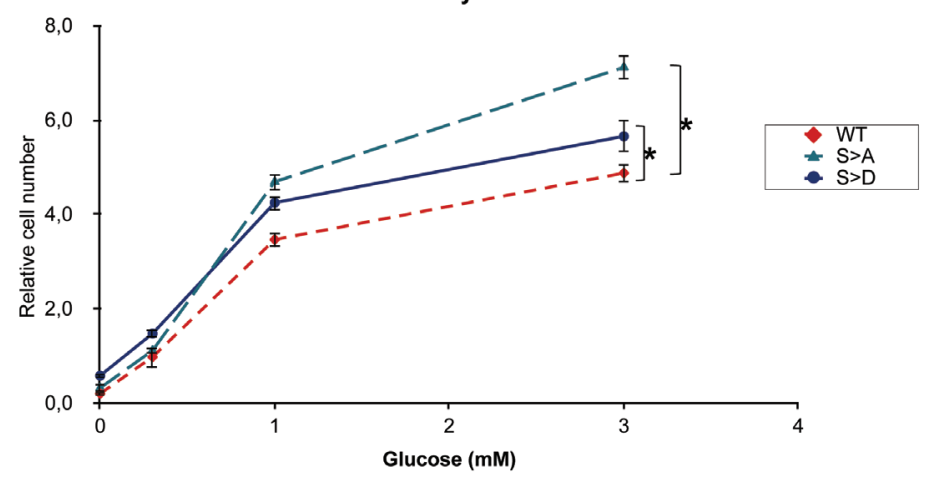

Figure 2. MNK1 $a^{S>D}$ mutation affects cell proliferation under stress. (A) Dose-response curve of U-2OS cells overexpressing MNK1 WT, S353A (S>A) and S353D (S>D) mutants to rapamycin. Cells were cultured for 4 days in the absence or presence of rapamycin at different concentrations $(0,5$, 10, $20 \mathrm{nM}$ ); cells with empty vector (ev) served as control. (B) MNK1-S353 phosphorylation promoted higher cell growth/survival under stress condition. U-2OS cells overexpressing MNK1 WT, S>A and $S>D$ mutants were cultured in medium with various low glucose concentrations $(0,0.3,1,3 \mathrm{mM})$. Cell numbers at day 6 are depicted in the graph. Cells numbers were measured by crystal-violet extraction assay (See: Methods section). Statistical test: Student's $t$-test MNK1a WT vs. MNK1a S>A/S>D mutants $(*: p<0.05)$.

consistently showed reduced proliferation rates compared to MNK1a ${ }^{\mathrm{WT}}$, MNK1 $\mathrm{a}^{\mathrm{S}>\mathrm{A}}$ cells (Figure 2A). This data indicated a higher sensitivity of MNK1a ${ }^{\mathrm{S}>\mathrm{D}}$ expressing cells to rapamycin. Given the GD-induced effect of MNK1a mutation on elF4E phosphorylation, we next tested the effect of metabolic stress on cell proliferation in the context of MNK1a mutation. At standard culturing conditions ( $25 \mathrm{mM}$ glucose) proliferation was similar for all MNK1a overexpression constructs (data not shown). Proliferation rate decreased when glucose was lower/absent in the culture medium. Under glucose-deprived conditions, however, the MNK1 $a^{\mathrm{s}>\mathrm{D}}$ consistently had a slight but significant proliferative 
advantage (Figure 2B). Beyond 4 days, cell numbers dropped sharply in all cultures, suggesting neither MNK1a overexpression nor mutation affected long-term metabolic stress-induced cell death (data not shown). This combined data suggests that under physiological stress, the MNK1 $\mathrm{a}^{\mathrm{S}>\mathrm{D}}$ mutant provided a temporal override of antiproliferative check-points that correlated with enhanced translational capacity. The enhanced sensitivity of MNK1 $\mathrm{a}^{\mathrm{S}>\mathrm{D}}$ for rapamycin supports the notion that mTOR signaling acts in concert with AMPK-MNK1a in cell proliferation and survival.

MNK1a stably binds AMPK in a MNK1a kinase activity independent manner

We have recently reported that AMPK and MNK1a physically interact (31). To further investigate this interaction in response to metabolic stress, a time-course glucose deprivation (GD) experiment was performed over a range of $24 \mathrm{hrs}$ and endogenous AMPK was immunoprecipitated (Figure 3A). Co-immunoprecipitation confirmed MNK1a as an AMPK binding partner at basal level and this interaction did not change significantly for up to $8 \mathrm{hrs}$ post-GD. We noticed that interaction between AMPK and MNK1a was dramatically enhanced at $24 \mathrm{hrs}$ post-GD. The increased binding to MNK1a occurred concomitantly with decreased overall cellular AMPK-T172 phosphorylation status (AMPK-pT172). Glucose-replenishment for $1 \mathrm{hr}$ at $24 \mathrm{hrs}$ post-GD, did not change the interaction of MNK1a with AMPK compared to 24 hrs post-GD, whereas it further reduced total cellular AMPK-pT172 (Figure 3A). These combined findings support the idea that the cellular AMPK:MNK1a complex formation is not dependent on phosphorylation status of MNK1a or AMPK. The MNK1a:AMPK physical interaction in response to sustained metabolic stress may point to a process that may be unrelated to early GD-induced changes in the AMPK or MNK1 activation status, and may be relevant for cell proliferation or survival-related processes.

To elucidate possible determinants regulating MNK1a-AMPK interaction, different MNK1 mutants were constructed with either altered catalytic activity (i.e. kinasedeficient $\mathrm{K}>\mathrm{M}$; M/SAPK-unresponsive $\mathrm{T} 2>\mathrm{A} 2$ ) or lack of $\mathrm{N}$-terminal or C-terminal interaction domains (Ndel, NLSyn, Cdel) (Figure 3B). The interaction capacity of these mutants with AMPK was verified at $24 \mathrm{hrs}$ post-GD. MNK1aWT overexpression cells showed the expected increased AMPK:MNK1a interaction upon $24 \mathrm{hrs}$ GD. Compared to the MNK1 $1 a^{\text {WT }}$ protein, the MNK1a ${ }^{\mathrm{T} 2>A 2}$ (M/SAPK-unresponsive) and MNK1a $a^{\mathrm{S}>\mathrm{A}}$ mutants did not show an obvious binding differences under these conditions (Figure $3 C$ ). Although showing a low expression level, MNK1 $\mathrm{a}^{\mathrm{K}>\mathrm{M}}$ interacted with endogenous AMPK at appreciable level. The MNK1 $\mathrm{a}^{\mathrm{NLSyn}}$ mutant that harbored an artificial NLS at the N-terminus (therefore mostly localized in nucleus) (see Chapter 5) displayed reduced binding to AMPK, suggesting that at $24 \mathrm{hrs}$, the AMPK-MNK1a interaction occurs preferentially in the cytosol (Figure $3 \mathbf{C}$ ). The MNK1a ${ }^{\text {cdel }}$ mutant that lacks the $\mathrm{C}$-terminal M/SAPK binding 
A ev

\begin{tabular}{lllllllll}
0 & 0 & 1 & 2 & 4 & 8 & 24 & 24 & $24(+1)^{\#}$ \\
\hline
\end{tabular}

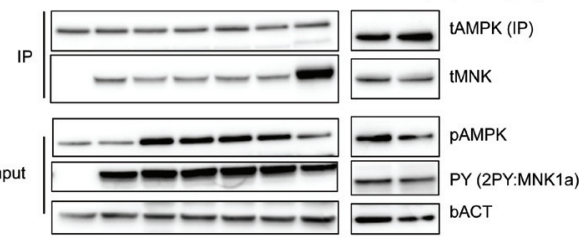

C

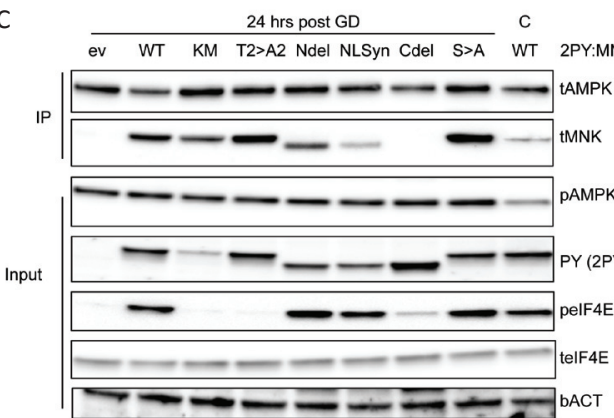

Figure 3. AMPK:MNK1 interaction is independent on MNK1 kinase activity. (A) MNK1 stably interacts with AMPK under prolonged metabolic stress. U-2OS cells expressing MNK1 ${ }^{\text {WT }}$ were glucosedeprived (GD) as indicated (in hours post GD), " cells were glucose deprived and then re-incubated with glucose for 1 hour. Cells carrying an empty vector (ev) served as control. Endogenous AMPK was immunoprecipitated (IP) using AMPK antibody. IB analyses of co-immunoprecipitated and input samples using the indicated antisera. (B) MNK1a constructs used in the study. Schematic representation of MNK1a showing the nuclear localization signal (NLS) and elF4G binding site, the kinase domain (ATP binding pocket marked by "K"), activation loop (T209/214, marked "TT"), the nuclear export signal (NES) and the MAP kinase binding. Serine 353 is marked as " $\mathrm{S}$ ". WT: wild-type; S>A/D: Serine 353>Alanine/Aspartic acid; K>M: Lysine 78>Methionine; T2>A2: T209/T214>A209/ A214; Ndel: deletion of 24 amino acids at N-terminal region; NLSyn: NLS replacement with an artificial NLS; Cdel: deletion of MAPK binding domain. (C) U-2OS cells expressing corresponding MNK1 mutants were metabolically stressed (GD) for 24 hours. Cells with empty vector (ev) and untreated cells with MNK1 ${ }^{\text {WT }}$ (C) served as control. Endogenous AMPK was immunoprecipitated (IP) using AMPK antibody. IB analyses co-immunoprecipitated and input samples using the indicated antisera.

domain could only be detected by using an antiserum detecting the 2PY-tag, as the tMNK1 antibody recognizes an epitope in this C-terminal region. However, the reciprocal immunoprecipitation of exogenous MNK1a using PY antibodies, allowed for successful detection of endogenous AMPK when mildly crosslinked by formaldehyde fixation before cell lysis. Using this protocol, the MNK1a ${ }^{\text {cdel }}$ mutant was found to interact with AMPK at basal levels (Supplementary Figure 2). Therefore, it could be concluded that at $24 \mathrm{hrs}$ post-GD a preferential cytosolic MNK1a:AMPK interaction is independent of MNK1a kinase activity.

\section{ERK controls AMPK-MNK1 complex formation and regulation}

Glucose deprivation over $24 \mathrm{hrs}$ followed by re-addition of glucose for $1 \mathrm{hr}$ previously 
A

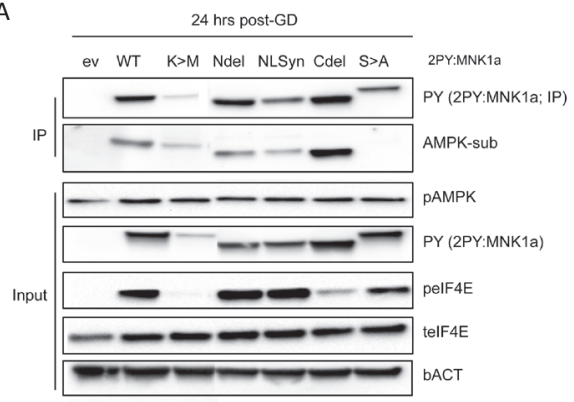

B

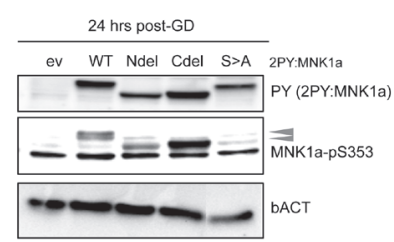

Figure 4. MNK1a C-terminal domain mediates MNK1-S353 phosphorylation. U-2OS cells expressing MNK1 mutants were treated with glucose deprivation (GD) for $24 \mathrm{hrs}$. Whole cell lysates were used for immunoprecipitation (IP, A) or immunoblotting (B). (A) MNK1 proteins were precipitated by using PY antibody and the immuno-complex and input samples were analyzed by antibodies as indicated.

(B) Cell lysates were analyzed by immunoblotting using antibodies as indicated.

revealed that MNK1-S353 phosphorylation is a reversible and dynamically controlled process (31). Since physical interaction of AMPK with MNK1a might correlate with phosphorylation at S353, we applied a similar treatment protocol but in combination with immunoprecipitation (IP) and AMPK-substrate antibody. In line with data shown in Figure 3A, AMPK activity increases after $1 \mathrm{hr}$ of GD and decreases upon re-administration of glucose at $24 \mathrm{hrs}$ post-GD. In further agreement with the observed strongly enhanced MNK1a:AMPK interaction at 24 hrs post-GD, the AMPK-dependent phosphorylation of MNK1a is highest at this time point (as indicated by the AMPK-substrate antibody) (Supplementary Figure 3). We recently proposed that the C-terminal domain of MNK1 may regulate the access of AMPK to MNK1-S353 for phosphorylation (31). Thus to further explore the effect of the MAPK-binding domain, MNK1a immunoprecipitation and AMPK-substrate antibody detection were applied to overexpressed MNK1aWT protein under the same condition ( 24 hrs post-GD). As expected, All MNK1a variant with an intact S353 showed S353 phosphorylation signal while MNK1a ${ }^{\text {S>A }}$ (negative control) was undetectable by the AMPK substrate antibody (Figure 4A). Remarkably, the MNK1a ${ }^{\text {cdel }}$ mutant that lacks the C-terminal MAPK binding domain, showed increased pS353, which is in line with the model and therefore was expected (31). This result was independently confirmed by analysis of cell lysates from MNK1a overexpressing cell lines using a site-specific phospho-MNK1 S353 antibody (pS353) (Figure 4B). Hence, the lack of the C-terminal MAPK-binding domain of MNK1a permits increased AMPKmediated MNK1a S353 phosphorylation. This finding is in good agreement with the proposed regulation of MNK1a by M/SAPKs.

We next asked how ERK and P38 activity affect MNK1a-S353 phosphorylation by AMPK in the context of metabolic stress. First the effect of ERK inhibition using MEK inhibitor U0126 was tested. In combination with GD 24 hours U0126 caused a dramatic 
A

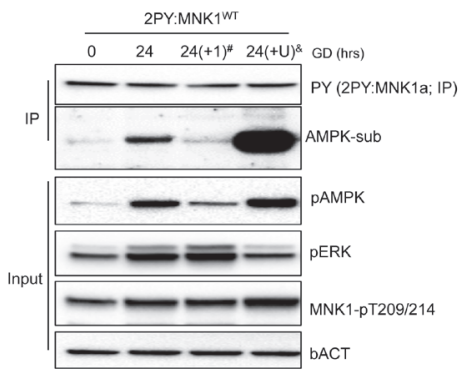

C

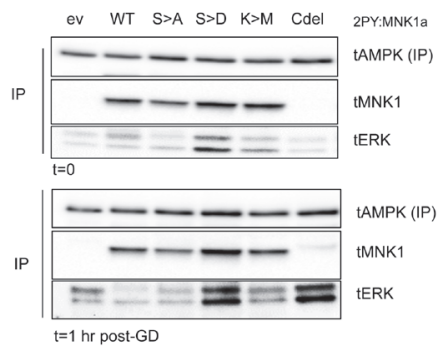

B
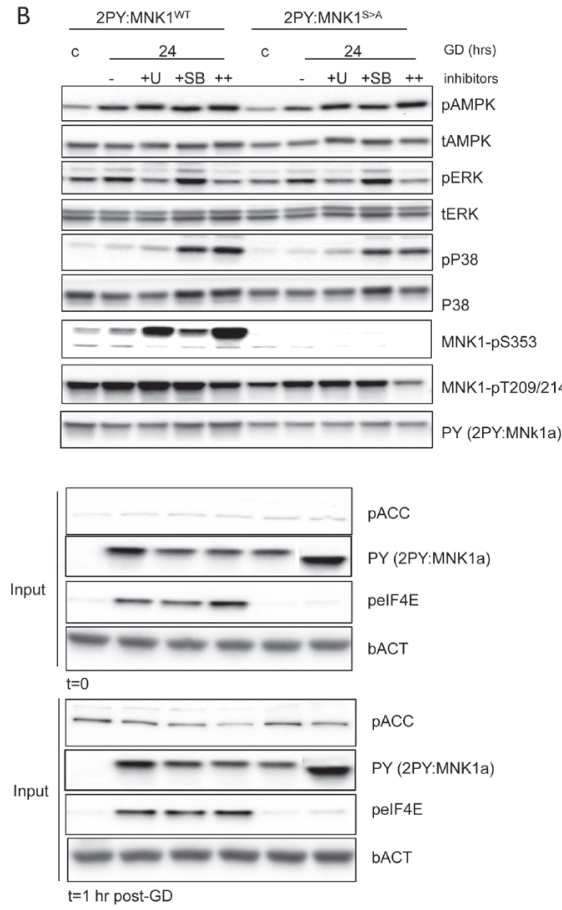

Figure 5. ERK control AMPK:MNK1a interaction. (A) U-2OS cells expressing MNK1 ${ }^{\text {WT }}$ were glucosedeprived (GD) for $24 \mathrm{hrs}$; untreated cells served as control. "cells were glucose deprived and then re-incubated with glucose for $1 \mathrm{hr}$; ${ }^{\&}$ cells were incubated with glucose-free medium containing MEK inhibitor U0126 (10 $\mu \mathrm{M})$ for $24 \mathrm{hrs}$. MNK1a proteins were precipitated by using PY antibody; immunocomplexes and the input samples were analyzed by antibodies as indicated. (B) U-2OS cells expressing MNK1a mutants were glucose-deprived (GD) for $24 \mathrm{hrs}$. MEKi (U0126, 10 MM) and P38i (SB202190, $20 \mu \mathrm{M})$ were used along with GD treatment separately (+U/+SB) or as double treatment (++). Cells untreated (c) served as control. Cell lysates were analyzed by immunoblotting with antibodies as indicated. (C) MNK1a-S353 phosphorylation promotes formation of AMPK:ERK complex. U-2OS cells expressing MNK1a mutants were untreated or glucose-deprived (GD) for $1 \mathrm{hr}$. Cells with empty vector (ev) served as control. Endogenous AMPK were immunoprecipitated (IP) using AMPK antibody. IB analyses co-IP and input samples using the indicated antibodies.

increase of MNK1a-S353 phosphorylation (AMPK-sub), while only a modest induction of AMPK activation (PAMPK) was observed (Figure 5A). Also, the MNK1 activation slightly increased, as evidenced by the stronger pMNK1a-T209/214 signal. These data were further validated and extended by using a P38 inhibitor (P38i) alone or in combination with a MEK/ERK inhibitor (MEKi) and detection by site-specific MNK1a-pS353 antibody; the MNK1a ${ }^{S>A}$ mutant was used as a control. P38i and MEKi independently induced MNK1a-S353 phosphorylation; the combination of both inhibitors was synergistic (Figure 5B). Nevertheless, MEKi inhibition appeared to be more effective in augmenting pS353 in the 24 hours GD condition. As ERK was identified as a binding partner for both AMPK (37) and MNK1a, we examined their interaction as part of a ternary complex in coimmunoprecipitation experiments (Figure 5C). Under basal conditions, AMPK, MNK1a 
and ERK formed an interaction complex and the MNK1 $1^{S>D}$ mutant showed more interaction of AMPK-ERK. It was further seen that, upon GD stress (IP: GD 1hr), MNK1 $1^{\text {cdel }}$ mutant, lacking ERK-binding domain, also resulted in higher level of ERK in the complex of AMPK:MNK1a. Taken together with the data that MNK1 $1^{\text {cdel }}$ mutation or MEKi led to higher level of S353 phosphorylation, it seems that MNK1a-S353 phosphorylation promoted AMPK:ERK interaction, that AMPK:ERK binding occurs independent on the interaction of MNK1a and ERK, and that MNK1a-S353 phosphorylation is negatively controlled by the presence of ERK in the ternary complex.

\section{Concluding discussion}

MNKs have been widely treated as cancer therapy target due to its key role in phosphorylating elF4E, which may regulate protein synthesis initiation via altered binding to the cap-structure of eukaryotic cytoplasmic mRNAs (38). However, the exact mechanism how phosphorylated elF4E controls protein translation remains unclear (3840). It is also unknown whether it regulates cellular translational level more generally or via specific mRNA translation control. As a result, the exact functional interaction of MNKs with elF4E remains undefined as well. Although the structural analyses of MNKs have revealed an interesting conceptual model $(5,17,20)$, also the complexity of MNK regulation requires detailed exploration.

We have demonstrated that AMPK-mediated MNK1a-S353 phosphorylation enhances its kinase activity with eIF4E phosphorylation under both basal and stressed conditions. Our observations may support a proposed model where elF4E phosphorylation affects mRNA translation: under normal condition with low phosphorylation of elF4E, short and unstructured 5'UTR-mRNAs ("strong" mRNAs) for basic cell function are mostly translated, e.g. $\beta$-actin; when more elF4E gets phosphorylated, long and structured 5'UTR-mRNAs ("weak" mRNAs) are then more translated, e.g. c-myc (41). Thus, a selective effect of elF4E phosphorylation is predicted, as it is also reasonable under conditions of stress to regulate the expression of certain targets instead of changing the global translational level. However, within the current experimental set-up, we have not been able to pinpoint such selective effect. Detailed analysis of translation capacity and specific mRNA translation under conditions where clear differences of elF4E phosphorylation are observed in the context of MNK1a mutation, should improve our understanding of the role of MNK1a-dependent elF4E phosphorylation.

In our study, MNK1a overexpression had an inhibitory effect on normal U-2OS cell proliferation. This result is in line with the observation that overexpression of Lk6 (MNK orthologue) in Drosophila resulted in growth inhibition (42), indicating a stressful and inhibitory role of MNK "overdose" on cell growth instead of promoting translation for proliferation. The observation that a higher cell growth/survival situation happening in 
cells overexpressing MNK1a further suggest a role of MNK1a in mediating cellular stressresponses, which could be unnecessary, or even "harmful" for normal cell growth. This idea has also been supported by our observation that cells overexpressing S353D mutant (AMPK-mediated MNK1 phosphorylation-mimic) lead to lower basal proliferation, whereas the same mutant showed higher proliferation/survival under stress (43). It is conceivable that under metabolic stress MNK1a/elF4E play a role in directing IRESmediated translation (44-46): MNK1a would control IRES rather than 5'cap-dependent translation. We are currently investigating this possibility.

The observation that deletion mutant of MAPK-binding domain (Cdel) showed high level of S353 phosphorylation provides functional confirmation of the extended regulatory model we have proposed in the previous study (31): the C-terminus covers the kinase domain of MNK1 at a "closed" state and MNK1 performs a conformational change to an "opened" state upon activation which could be easily accessed by AMPK. Considering the functional interaction of ERK in a complex with AMPK and MNK1a, two possibilities should be mentioned here: on one hand, due to the fact that MNK1a binds more strongly with inactive than active ERK (5), inhibition of ERK activity would yield more "opened" MNK1 proteins which are easier for AMPK to access. On the other hand, suppression of ERK activity was suggested to relieve its inhibitory effect on LKB1-AMPK signaling (47) and thus more activated AMPK would be available toward MNK1 phosphorylation. This could suggest that multiple, perhaps successive, M/SAPKmediated phosphorylation events determine MNK1a conformational changes, its interaction with AMPK and negative feedback on this process.

Taken together with the previous study (Chapter 3), we have identified AMPK as a novel upstream kinase for MNK1 S353 phosphorylation, which is a stress-related dynamic process and not necessary for MNK1 activation. As a stable binding partner of AMPK, MNK1a is tightly regulated by its C-terminal MAPK-binding region for AMPK-mediated S353 phosphorylation and ERK has been found to be an important regulator of both the functional and physical interaction between AMPK and MNK1. However, several problems are still unanswered in our setting. As a broad view, although the exact role of MNK1-eIF4E remains undecided for now, we have found that it seems to be a part of a protective process for cell proliferation/survival under stress, especially as an effect of MNK1-S353 phosphorylation. We anticipate that further identification of interaction partners for AMPK and MNK1a in the context of cell stress is expected to contribute to a better understanding of MNK1 function and to provide more insights in possibilities to develop AMPK/MNK1a and translation as a target in cancer treatment. 


\section{References}

1. Grzmil, M., and Hemmings, B. A. (2012) Cancer Res 72, 3891-3900

2. Bhat, M., Robichaud, N., Hulea, L., Sonenberg, N., Pelletier, J., and Topisirovic, I. (2015) Nat Rev Drug Discov 14, 261-278

3. Diab, S., Kumarasiri, M., Yu, M., Teo, T., Proud, C., Milne, R., and Wang, S. (2014) Chem Biol 21, 441-452

4. Hou, J., Lam, F., Proud, C., and Wang, S. (2012) Oncotarget 3, 118-131

5. Waskiewicz, A. J., Flynn, A., Proud, C. G., and Cooper, J. A. (1997) Embo J 16, 1909-1920

6. Mamane, Y., Petroulakis, E., Rong, L., Yoshida, K., Ler, L. W., and Sonenberg, N. (2004) Oncogene 23, 3172-3179

7. Wheater, M. J., Johnson, P. W., and Blaydes, J. P. (2010) Cancer Biol Ther 10, 728-735

8. Ramalingam, S., Gediya, L., Kwegyir-Afful, A. K., Ramamurthy, V. P., Purushottamachar, P., Mbatia, H., and Njar, V. C. (2014) Oncotarget 5, 530-543

9. Lim, S., Saw, T. Y., Zhang, M., Janes, M. R., Nacro, K., Hill, J., Lim, A. Q., Chang, C. T., Fruman, D. A., Rizzieri, D. A., Tan, S. Y., Fan, H., Chuah, C. T., and Ong, S. T. (2013) Proc Natl Acad Sci U S A 110, E2298-2307

10. Bianchini, A., Loiarro, M., Bielli, P., Busa, R., Paronetto, M. P., Loreni, F., Geremia, R., and Sette, C. (2008) Carcinogenesis 29, 2279-2288

11. Ueda, T., Watanabe-Fukunaga, R., Fukuyama, H., Nagata, S., and Fukunaga, R. (2004) Mol Cell Biol 24, 6539-6549

12. Gorentla, B. K., Krishna, S., Shin, J., Inoue, M., Shinohara, M. L., Grayson, J. M., Fukunaga, R., and Zhong, X. P. (2013) J Immunol 190, 10261037

13. Fukunaga, R., and Hunter, T. (1997) Embo J 16, 1921-1933

14. Orton, K. C., Ling, J., Waskiewicz, A. J., Cooper, J. A., Merrick, W. C., Korneeva, N. L., Rhoads, R. E., Sonenberg, N., and Traugh, J. A. (2004) J Biol Chem 279, 38649-38657

15. Wang, X., Yue, P., Chan, C. B., Ye, K., Ueda, T., Watanabe-Fukunaga, R., Fukunaga, R., Fu, H., Khuri, F. R., and Sun, S. Y. (2007) Mol Cell Biol 27, 7405-7413

16. Scheper, G. C., Morrice, N. A., Kleijn, M., and Proud, C. G. (2001) Mol Cell Biol 21, 743-754

17. Parra, J. L., Buxade, M., and Proud, C. G. (2005) J Biol Chem 280, 37623-37633

18. Buxade, M., Parra-Palau, J. L., and Proud, C. G. (2008) Front Biosci 13, 5359-5373

19. O’Loghlen, A., Gonzalez, V. M., Pineiro, D., Perez-Morgado, M. I., Salinas, M., and Martin,
M. E. (2004) Exp Cell Res 299, 343-355

20. O’Loghlen, A., Gonzalez, V. M., Jurado, T., Salinas, M., and Martin, M. E. (2007) Biochim Biophys Acta 1773, 1416-1427

21. Muller, D., Lasfargues, C., El Khawand, S., Alard, A., Schneider, R. J., Bousquet, C., Pyronnet, S., and Martineau, Y. (2013) Translation (Austin) 1, e25819

22. Mader, S., Lee, H., Pause, A., and Sonenberg, N. (1995) Mol Cell Biol 15, 4990-4997

23. Bjornsti, M. A., and Houghton, P. J. (2004) Cancer Cell 5, 519-523

24. Showkat, M., Beigh, M. A., and Andrabi, K. I. (2014) Mol Biol Int 2014, 686984

25. Huang, J., and Manning, B. D. (2008) The Biochemical journal 412, 179-190

26. Gwinn, D. M., Shackelford, D. B., Egan, D. F., Mihaylova, M. M., Mery, A., Vasquez, D. S., Turk, B. E., and Shaw, R. J. (2008) Mol Cell 30, 214-226

27. Hay, N., and Sonenberg, N. (2004) Genes Dev 18, 1926-1945

28. Garber, K. (2001) J Natl Cancer Inst 93, 15171519

29. Law, B. K. (2005) Crit Rev Oncol Hematol 56, 4760

30. Scheper, G. C., van Kollenburg, B., Hu, J., Luo, Y., Goss, D. J., and Proud, C. G. (2002) J Biol Chem 277, 3303-3309

31. Zhu, X., Dahlmans, V., Thali, R. P., C., Viollet, B., Voncken, J. W., and Neumann, D. (2016) J Biol Chem accepted for publication

32. Morgenstern, J. P., and Land, H. (1990) Nucleic Acids Res. 18, 3587-3596

33. Kinsella, T. M., and Nolan, G. P. (1996) Hum. Gene Ther. 7, 1405-1413

34. Schmidt, E. K., Clavarino, G., Ceppi, M., and Pierre, P. (2009) Nat Methods 6, 275-277

35. Starck, S. R., Green, H. M., Alberola-lla, J., and Roberts, R. W. (2004) Chem Biol 11, 999-1008

36. Miyamoto-Sato, E., Nemoto, N., Kobayashi, K., and Yanagawa, H. (2000) Nucleic Acids Res 28, 1176-1182

37. Lopez-Cotarelo, P., Escribano-Diaz, C., GonzalezBethencourt, I. L., Gomez-Moreira, C., Deguiz, M. L., Torres-Bacete, J., Gomez-Cabanas, L., Fernandez-Barrera, J., Delgado-Martin, C., Mellado, M., Regueiro, J. R., Miranda-Carus, M. E., and Rodriguez-Fernandez, J. L. (2015) J Biol Chem 290, 827-840

38. Proud, C. G. (2015) Biochim Biophys Acta 1849, 766-773

39. Hsieh, A. C., and Ruggero, D. (2010) Clin Cancer Res 16, 4914-4920 
40. Hay, N. (2010) Proc Natl Acad Sci U S A 107, 13975-13976

41. De Benedetti, A., and Graff, J. R. (2004) Oncogene 23, 3189-3199

42. Reiling, J. H., Doepfner, K. T., Hafen, E., and Stocker, H. (2005) Curr Biol 15, 24-30

43. Teo, T., Yu, M., Yang, Y., Gillam, T., Lam, F., Sykes, M. J., and Wang, S. (2015) Cancer Lett 357, 612623

44. Komar, A. A., and Hatzoglou, M. (2011) Cell Cycle 10, 229-240
45. Holcik, M., and Sonenberg, N. (2005) Nat Rev Mol Cell Biol 6, 318-327

46. Joshi, S., and Platanias, L. C. (2014) World J Biol Chem 5, 321-333

47. Kawashima, I., Mitsumori, T., Nozaki, Y., Yamamoto, T., Shobu-Sueki, Y., Nakajima, K., and Kirito, K. (2015) Exp Hematol 43, 524-533 e521 


\section{Supplemental information}

Translation measurement

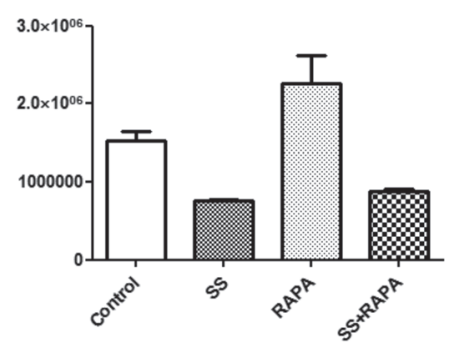

Supplementary Figure 1. Cellular translation measurement by puromycin assay. U-2OS cells were treated as indicated. SS: serum starvation for $16 \mathrm{hrs}$; RAPA: $20 \mathrm{nM}$ rapamycin for $1 \mathrm{hr}$; SS+RAPA: 20 $\mathrm{nM}$ rapamycin for $1 \mathrm{hr}$ following SS. Cellular translational rate was measured by a puromycin labelling assay.

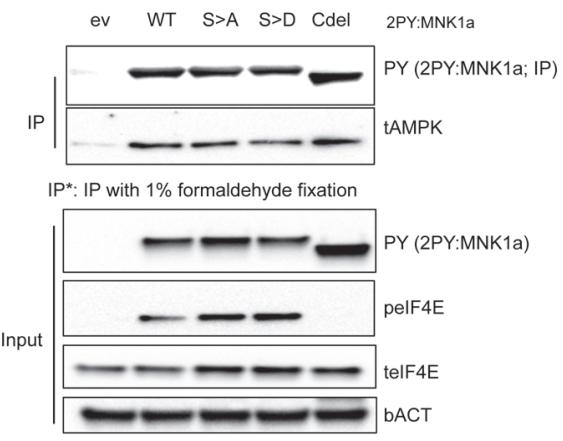

Supplementary Figure 2. MNK1a'ael mutant interacts with AMPK under basal condition. U-2OS cells expressing MNK1 mutants were untreated. Cells with empty vector (ev) served as control. Cells were fixed with $1 \%$ formaldehyde for 10 minutes and the fixation was stopped by $0.2 \mathrm{M}$ glycine (freshly prepared) for 5 minutes, prior to cell lysis. MNK1a protein was immunoprecipitated (IP) using PY antibody. IB analyses IP-ed and input samples using the indicated antibodies.

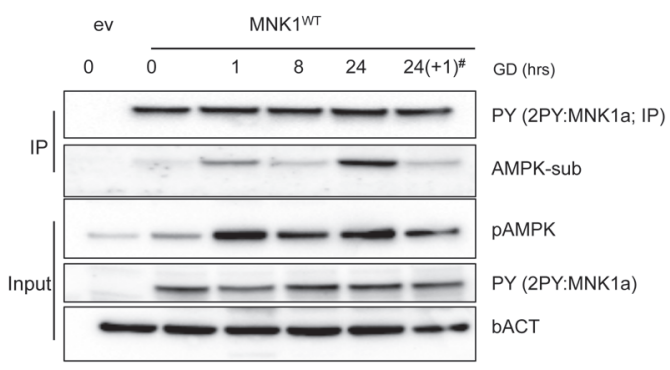

Supplementary Figure 3. AMPK-mediated MNK1 phosphorylation is a dynamic regulated process upon metabolic stress. U-2OS cells expressing MNK1 mutants were glucose-deprived (GD) as indicated (in hrs), "cells were glucose-deprived and then incubated with glucose re-administered for 1 hour. Cells with empty vector (ev) served as control. MNK1 proteins were immunoprecipitated (IPed) using PY antibody. IB analyses IP-ed and input samples using the indicated antibodies. 


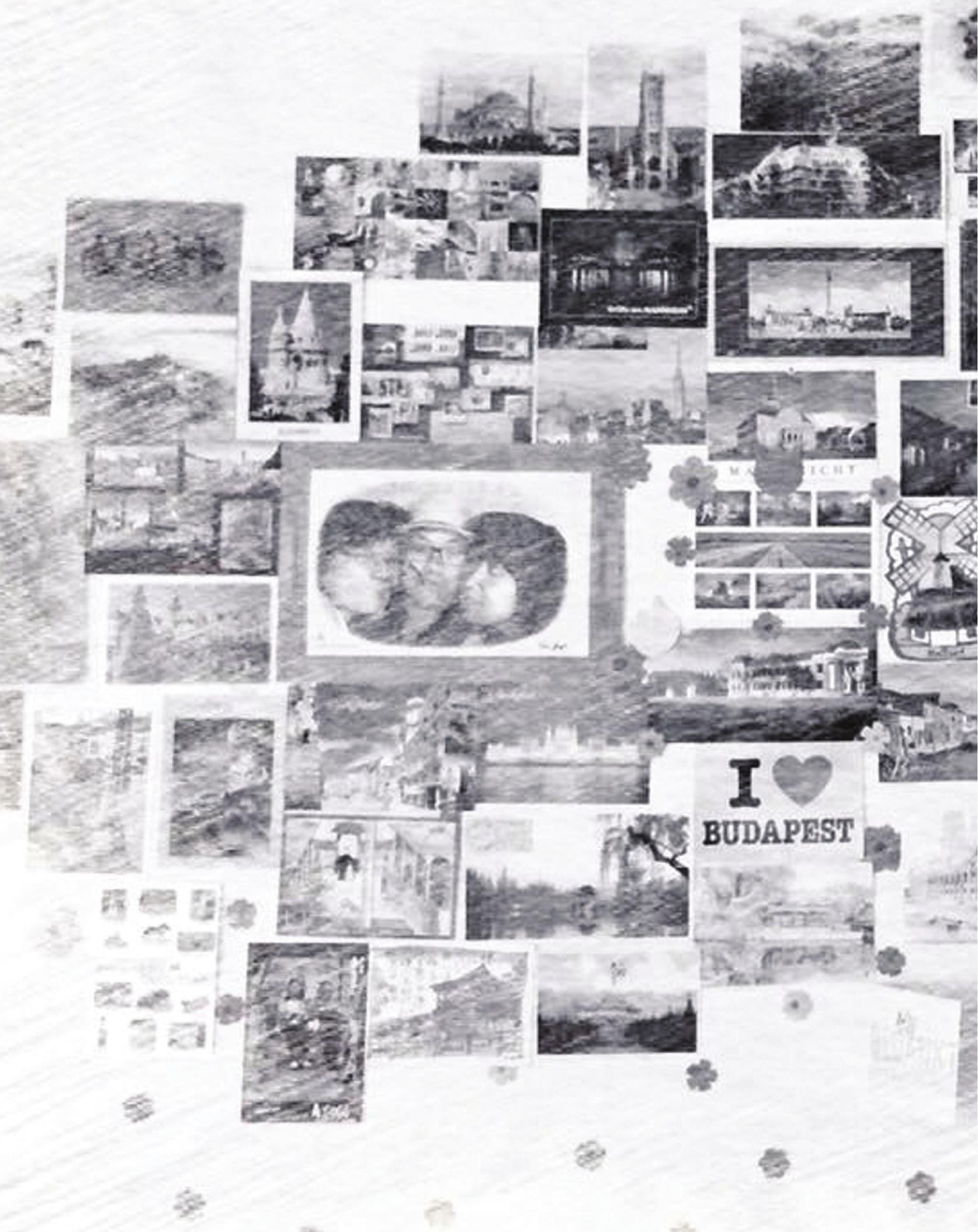




\title{
- '(4)
}

\section{Ghapter 6}

\author{
General Discussion
}
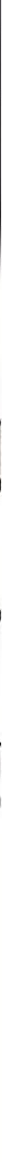


\section{Main findings of the thesis}

As an energy sensor which is activated by a low intracellular ATP level, AMPK is involved in a great variety of cellular processes, e.g. metabolism, growth, autophagy, polarity and migration (1). Despite a growing list of AMPK targets in the context of metabolism, studies aimed at revealing additional targets remain urgent to determine the relevance of AMPK in pathological conditions, such as metabolic syndrome or cancer (2). In a previous protein microarray screening for AMPK substrate proteins, MNK1 appeared as a promising AMPK target with highest score.

In this thesis, the AMPK-MNK1a signaling axis was identified and further investigated revealing potential roles in the regulation of both translation/cell growth and transcription. The main cornerstones and findings of this thesis are as follows:

1. A methodological overview summarizes the most prevalent in-vitro methods for the study of AMPK (Chapter 2)

2. A workflow protocol describes the necessary steps for AMPK novel target identification and verification in vitro. (Chapter 2)

3. AMPK phosphorylates MNK1a at S353 in vitro and in cells. (Chapter 3)

4. MNK1a S353 phosphorylation enhances its kinase activity toward elF4E phosphorylation. (Chapter 3)

5. Cell survival upon metabolic stress is promoted by AMPK-mediated MNK1a S353 phosphorylation. (Chapter 4)

6. AMPK, MNK1 and ERK are part of a ternary complex and AMPK-mediated MNK1 S353 phosphorylation is regulated by ERK via the C-terminal region of MNK1. (Chapter 4)

7. AMPK, MNK1a and EGR1 bind to chromatin and engage in complex formation that controls the subcellular localization of AMPK during adaptive responses to metabolic stress. (Chapter 5 )

8. Initial analyses suggest that AMPK and MNK1a, in concert with EGR1, are required to tune the second phase of the adaptive transcriptional response. (Chapter 5)

In conclusion, the studies give rise to a novel signaling branch of AMPK regulating MNK1a. Further, new insights in the functional links between AMPK, ERK and MNK1a are provided. As shown, these findings are relevant in cell stress responses. In this current chapter, a few selected topics are discussed. Firstly, the focus is on elF4E that appears to be regulated by AMPK via mTOR and MNK1a. Secondly, an effect of MNK1a protein level on cell growth control is proposed. Thirdly, the MNK1a activation mechanism by phosphorylation is revisited. Fourthly, the known cross-talk between AMPK and ERK 
pathways is contrasted with the novel AMPK-MNK1a signaling. Finally, the MNK1:AMPK:ERK complex in the context of transcriptional regulation is debated.

\section{(1) The translational regulator elF4E is controlled by AMPK via two dif- ferent pathways}

Cell growth and cell cycle progression are cellular processes with direct relevance for cell proliferation. In these processes, protein translation is an essential and highly energyconsuming activity. Therefore, protein translation requires immediate and fast responses for cellular adaptation to changes in the microenvironment. Regulation of protein translation occurs at three levels: translation initiation, elongation and termination (3). Regarding the complexity of its regulation, translation-initiation has been described as the most crucial step. Among all the regulators, elF4E is believed to act as a rate-limiting factor based on its direct binding to mRNA with 5' cap-structure and guiding the complex formation with ribosomes (4). Two separate signaling pathways tightly regulate the activity of elF4E in response to stimuli: M/SAPKàMNK1/2 and mTORà4E-BPs (elF4E binding proteins) $(5,6)$. Since protein translation is a major ATP consuming process, AMPK has been extensively studied for its regulatory involvement. It is now well established that AMPK inhibits mTOR activity (through several mechanisms), resulting in the inhibitory occupation of elF4E by $4 \mathrm{E}-\mathrm{BPs}$, thus identifying AMPK as a suppressor of cell proliferation under nutrient deprivation (7). The functional connection of AMPK to the other translational control pathway involving M/SAPK and MNK1/2 was unknown. However, the studies on the novel functional link between AMPK and MNK1a (Chapter 3) suggest the existence of such additional AMPK-mediated control mechanism that can trigger increased elF4E phosphorylation (Figure 1).

As a potential oncogene, elF4E overexpression has been found to correlate with tumor progression via its anti-apoptotic effect (8). Yet, the role of elF4E in translation regulation remains unclear and knowledge about its regulation is similarly scarce. Currently, the most reliable theory of elF4E-mediated translation is based on structural features of mRNAs: although in general elF4E increases the global protein synthesis, under normal condition its availability is low, which is believed to be sufficient for translation of "strong" mRNAs (short and unstructured 5'- UTR), which are essential for maintenance of cell function, e.g. $\beta$-actin. When more elF4E becomes available, i.e., by stimulation of mTOR or overexpression of elF4E, "weak" mRNAs (long and structured 5 '- UTR) are then also translated. Such factors are essential for cell proliferation and survival, e.g. c-myc and cyclin-D1 (8-10). Following this line of reasoning, it would be conceivable to view AMPK-mediated MNK1 phosphorylation in the context of adaptation under metabolic stress, as seen by the effects on cell survival (Chapter 4, Figure 2B) via increased elF4E phosphorylation (Chapter 3, Figure 2D). Subsequently, "weak" mRNAs 


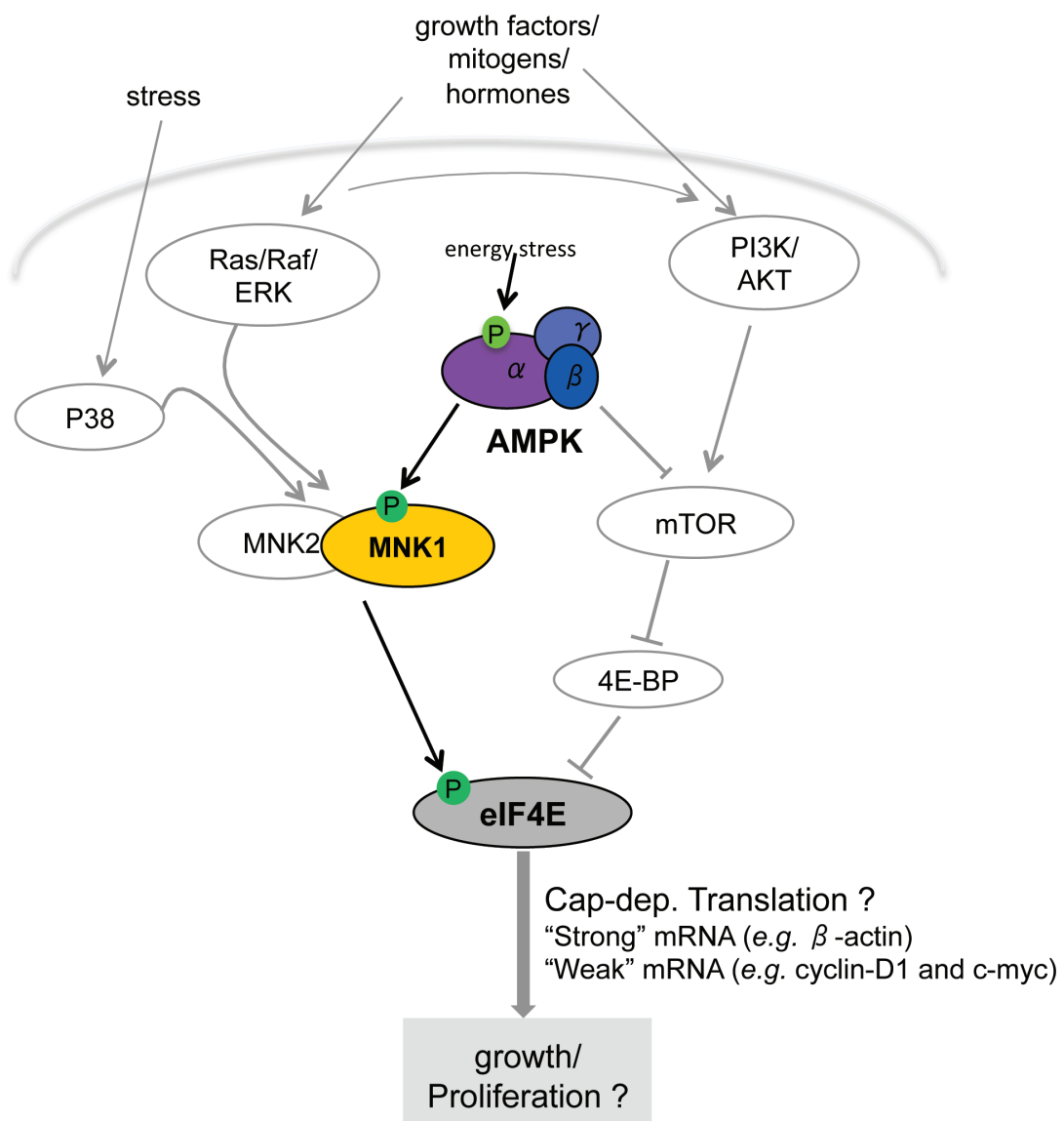

Figure 1. Involvement of AMPK in signaling pathways that regulate eIF4E. As a rate-limiting factor in translation initiation, elF4E is regulated by two signaling pathways: MNK1/2 and mTOR. According to the prevalent view (8), elF4E mainly directs cap-dependent translation initiation and its limited availability may decide for a selective translation of "strong" over "weak" mRNAs. However, the role of elF4E phosphorylation in cell growth/proliferation control remains unclear. MNK1/2 directly phosphorylate elF4E as a downstream target. The activity of MNK1/2 is stimulated by ERK and P38 in response to growth factors/mitogens via Ras-Raf or stress, respectively. By inhibiting the activity of elF4E-binding proteins (4E-BPs), mTOR increases eIF4E availability. AKT signaling, activated by a variety of growth factors, mitogens and hormones, induces the activation of MTOR; while AMPK (upon energy stress) counteracts eIF4E release by inhibiting mTOR signaling. Therefore, AMPK decreases elF4E availability, while simultaneously supporting its phosphorylation. The highlighted proteins and phosphorylation events are described in Chapter 3.

may be translated without the need for upregulation of global translation, which could allow for cellular adaptation despite generally reduced protein synthesis. If true, it would provide a function to elF4E phosphorylation, i.e., solving a long-standing issue. However, such hypothesis at present is far-fetched and clearly requires further investigation. Notably, by inference our data suggest that enhanced induction of elF4E phosphorylation by a constitutively active MNK1a ${ }^{5353 \mathrm{D}}$ mutant, is "harmful" to cell growth under normal 
growth condition (Chapter 4, Figure $\mathbf{2 A}$ ), which may be explained by the production of (for this situation) inappropriate stress-related proteins. Relevantly, screening for specific MNK-dependent protein changes at translational level could provide valuable leads to directly reveal phospho-eIF4E targets. Our results also emphasize a crucial role for MNK1a as a pivotal integrator of extracellular stimuli and intracellular signals. From our data one could derive a protective function of MNK1 allowing the cell to preserve a limited orchestra of protein translation/cell growth in response to stresses that would otherwise be blunted via mTOR inhibition. In summary, two different signaling branches both controlled by AMPK regulate eIF4E and further studies are needed to unveil their exact roles and contributions.

\section{(2) MNK1 "dosage" effect on cell growth control}

MNK1 and MNK2 have been found to be dispensable for normal cell growth and even mouse development $(11,12)$. However, MNK1/2 exhibit anti-apoptotic effects upon serum starvation (13) and their deficiency inhibits tumor formation in both cancer cells and mouse models of tumorigenesis (14-16). In this current thesis work, similar results were observed in two different cell lines. MNK1 knock-down (KD) reduced both fatty acid and glucose uptake in mouse HL-1 cardiomyocytes (likely via inducing senescence; pilot study) (Figure 2). Further, U2OS cells that express low levels of endogenous MNK1 underwent cell death upon infection of shRNA for MNK1 knockdown, leading to a failure of stable cell line generation (personal observations; data not shown). These observations support a crucial role of MNK1 in cell growth. Lowering the amount of endogenous MNK1, or complete lack of this kinase, seems to inhibit cell proliferation/ growth in cancer cell lines. Vice versa MNK overexpression (OE) was barely used in the context of investigating its effects on cell growth. In a previous study, it has been demonstrated that loss of LK6 (Drosophila Mnk1/Mnk2 Homolog) induced growth reduction upon reduced diet (stress), while overexpression also inhibited growth even under normal diet (17). Taking into consideration data showing reduced U-2OS cell proliferation upon MNK1-OE (Chapter 4, Figure 2A), we might actually observe a "dosage" effect of MNK1 on cell growth control. Interestingly, overexpression of MNK1, especially S353D mutant mimicking AMPK-mediated phosphorylation, appeared to support cell proliferation under stress condition longer than wild-type (Chapter 4, Figure 2B). These observations may also be consistent with the fact that MNK1 KO (Knock-out) mouse models did not show any phenotype. However, viability, metabolism and development may be affected once stress would be applied to these mice, but as yet such data has remained scarce. Hence, the underlying molecular and physiological mechanisms of the altered cell proliferation should be examined in detail under conditions of cellular stress using both MNK1 KD and OE models. 
A

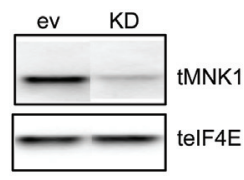

C

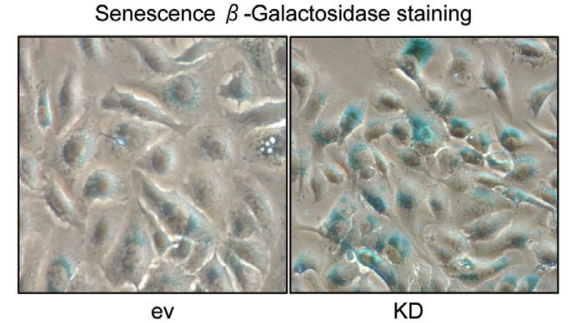

B
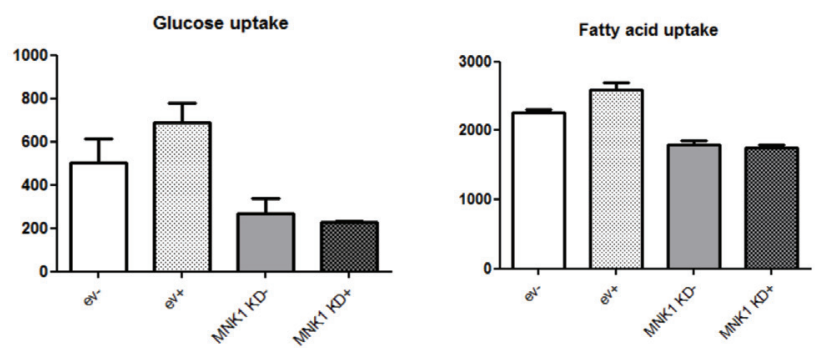

Figure 2. MNK1a knock-down in HL-1 cells reduced both glucose and fatty acid uptake probably via induction of senescence. (A) MNK1a knock-down (KD) in HL-1 cells was achieved by infection of lenti-virus containing shRNA targeting MNK1a mRNA 3' UTR. Cells infected by lenti-virus containing empty vector (ev) served as control. KD efficiency was indicated by immunoblotting with tMNK1a antibody. (B) Pilot study: HL-1 cardiomyocyte cell lines (ev/KD) were serum starved for 16 hours. Uptake of 2-Deoxy-D-[1- $\left.{ }^{3} \mathrm{H}\right]$ glucose and $\left[1-{ }^{14} \mathrm{C}\right]$ palmitic acid were measured with $(+) /$ without $(-)$ insulin treatment. (C) $\beta$-Galactosidase staining was done as indication of senescence.

\section{(3) The molecular process of MNK1a activation.}

ERK and p38 are targeting MNK1a at T209/T214, which to date are the best-studied MNK1 phosphorylation sites. Although T344 phosphorylation in the C-terminus of MNK1a has been identified, its regulation by upstream kinase is unknown (18). We have identified S353 as an AMPK target site. However, initially, we also considered S353 as a potential MNK1a autophosphorylation site. Hence, in-vitro kinase (IVK) assays (as described in Chapter 3) were performed with purified recombinant MNK1aWT and MNK1 ${ }^{\mathrm{KM}}$ (kinase-dead mutant) proteins that were exposed to active ERK in presence or absence of radiolabelled ATP. The displayed autoradiograph indicated the efficiency of the IVK (Figure $3 A$, upper panel). MNK1 $a^{\mathrm{KM}}$ showed reduced signal level, which may correspond to the lower MNK1a protein level, as indicated by CBB staining (Figure 3A, lower panel). Parallel assays were performed using 'cold' ATP for mass spectrometric (MS) analysis. In both MNK1 $\mathrm{a}^{\mathrm{WT}}$ and MNK1 $\mathrm{a}^{\mathrm{KM}} \mathrm{T} 344$ and S180/S185 were identified as phosphorylation sites in presence of active ERK and ATP, and the induction of these phosphorylation events showed no difference between MNK1 $\mathrm{a}^{\mathrm{WT}}$ and MNK1 $\mathrm{a}^{\mathrm{KM}}$ samples. S353 remained unphosphorylated in this assay. It is further noted that T209/T214 were not detected by MS, which presumably is due to the protein peptide comprising these sites is very large after trypsinisation and thus remains undetectable in MS. As shown in 

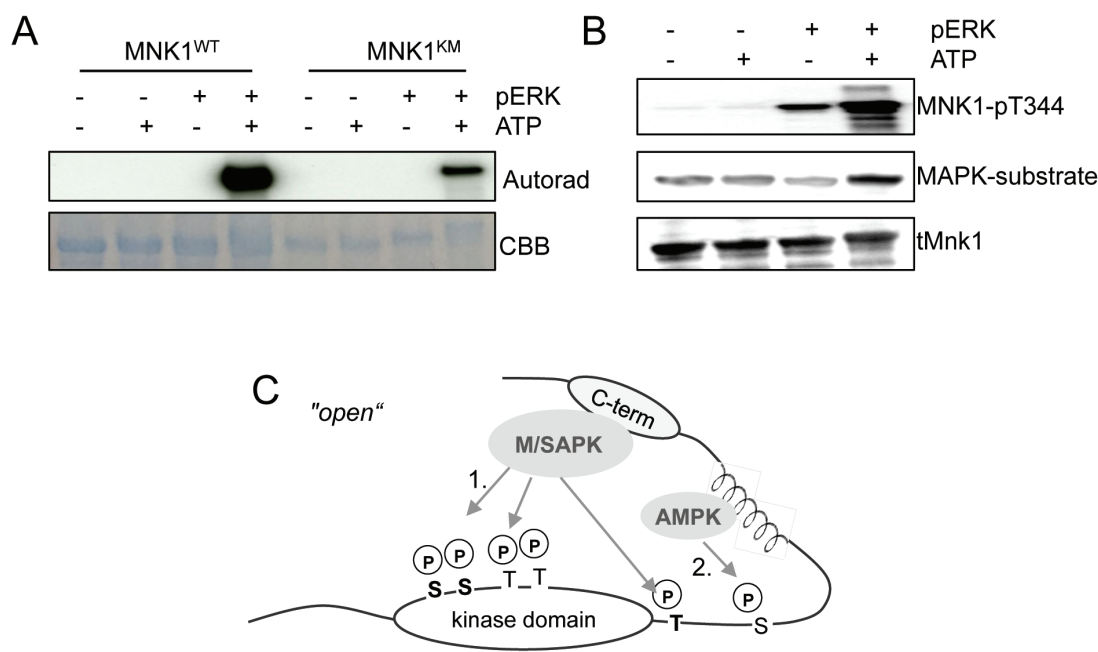

Figure 3. Post-translation modifications of MNK1 by ERK. (A) IVK: purified GST:MNK1aWT and mutant GST:MNK1 $1 a^{\mathrm{KM}}$ were incubated with or without active ERK in presence of [ $\left.\gamma^{-32} \mathrm{P}\right]$ ATP. pMNK1a: autoradiograph (upper panel); Coomassie Brilliant Blue-staining (CBB) image: loading control. (B) Immunoblots with indicated antisera of the same IVKs as in (A) but using 'cold'/non-radioactive ATP. (C) Post-translation modifications in MNK1a "open" conformation model. In the context of metabolic stress, ERK and P38 (M/SAPK) bind the C-terminal binding domain (C-term) of MNK1a and subsequently mediate phosphorylation (encircled 'P's) at MNK1a-S180/S185 (bold 'SS'), T209/T214 ('TT') and T344 (bold ' $\mathrm{T}$ ') in unknown orders (marked as ' 1 ' as the prerequisite step). AMPK then mediates MNK1a S353 phosphorylation ('S') to stabilize it in an active 'open' conformation (marked as '2').

Western blot data, MNK1aWT samples in the presence of pERK were detected by MNK1 pT344 and MAPK substrate (PXpS/pTP motif) antisera (Figure $3 \mathbf{B}$ ).

Based on these data we cannot generally exclude MNK1 autophosphorylation. However, the results are in support of MNK1-S353 phosphorylation as not being ERKdependent but AMPK-mediated (Chapter 3). Moreover we here describe for the first time that S180/S185 and T344 may be direct targets of ERK. Although the mechanistic implications for the regulation of MNK1 kinase activity are currently unclear, these observations suggest that MNK1a is subject to more complex regulation than is currently supported by literature. It has been reported that T344A/E mutants not only increase basal/TPA-induced MNK1 kinase activity, but may also induce conformational changes in the C-terminus (19), i.e., therefore T344 may have a similar function as S353 phosphorylation. Phosphorylation of S180/S185 is not evident from specific MNK literature, even though several high-throughput proteomics approaches have evidenced the phosphorylation of this site (www.phosphosite.org). Remarkably, instead of a common DFG motif in other kinases, MNK1a contains a unique DFD motif (Asp191Phe192-Asp193) and adopts a DFG/DFD-out conformation, which prevents the 
accessibility of ATP to the ATP-binding pocket and thus keeps the kinase in an inactive state (20). Therefore, it has remained elusive how an active kinase conformation may evolve upon T-loop phosphorylation. Since S180/S185 sites are close to the DFD-motif, it is tempting to speculate that their phosphorylation might be required for DFD/DFG-in conformation as a prerequisite of MNK1a kinase activity. Hence, as an extension of the model that was presented in Chapter 3, we here propose a MNK1a activation model that incorporates the possible implications of S180/S185 and T344 phosphorylation: M/ SAPKs may thus create an "open" configuration of MNK1a by carrying out multiple phosphorylations: a) T209/214, b) S180/185, c) T344 (“T" bold) (Figure 3C). Next AMPK may come into play to phosphorylate S353 and thereby further stabilize the open conformation (Chapter 3). However, at present we cannot conclude on the order of events or their individual function. It also remains unclear which of the newly identified ERK targeted MNK1 sites are similarly phosphorylated by P38. Therefore, further investigation of the exact molecular details of MNK1 kinase activity regulation and how these may be tuned to specific needs of a cell in any given context still remain necessary.

\section{(4) Inhibitory cross-talk between LKB1-AMPK and Raf-MEK-ERK path- ways: A role for AMPK-MNK1a signaling?}

ERK function has been mainly linked to regulation of cell proliferation and survival, also in response to a multitude of stressors among which nutrient deprivation. Since ERK associates with AMPK, we have studied the potential tripartite regulatory interaction between AMPK, MNK1 and ERK. In Chapter 4, ERK has been found as a physical interaction partner of the AMPK:MNK1 complex. Inhibition of ERK increased AMPKmediated MNK1 phosphorylation significantly (Chapter 4, Figure 5), which indicates an inhibitory effect of ERK on AMPK-mediated phosphorylation of MNK1. This observation is consistent with previous reports that ERK inhibition inversely correlates with AMPK activation level (21-23) and that AMPK could be a target of ERK in cell proliferation (21). Of additional relevance in this context, ERK was shown to be involved in negative regulatory feedback on AMPK, via the LKB/AMPK axis $(24,25)$. AMPK also inhibits ERK either via BRAF (an individual RAF protein) that is an upstream kinase of MEK/ERK, or via induction of DUSPs (dual-specificity phosphatases), which are negative regulators of ERK activation $(26,27)$. Thus, an intricate, reciprocal inhibitory cross-talk between ERK and AMPK is evident from literature that is likely to impact on ERK- and AMPK-dependent MNK1a regulation (Figure 4). This upstream signaling network puts an extra challenge on obtaining a clear picture of the regulatory events involved. As MNK1a is a downstream target of both Raf-MEK-ERK and, once in an open conformation, subsequently by LKB1AMPK, the relevance of AMPK-MNK1a signaling should be restricted to conditions when both pathways are active. It should also be mentioned that P38, i.e., the alternative 


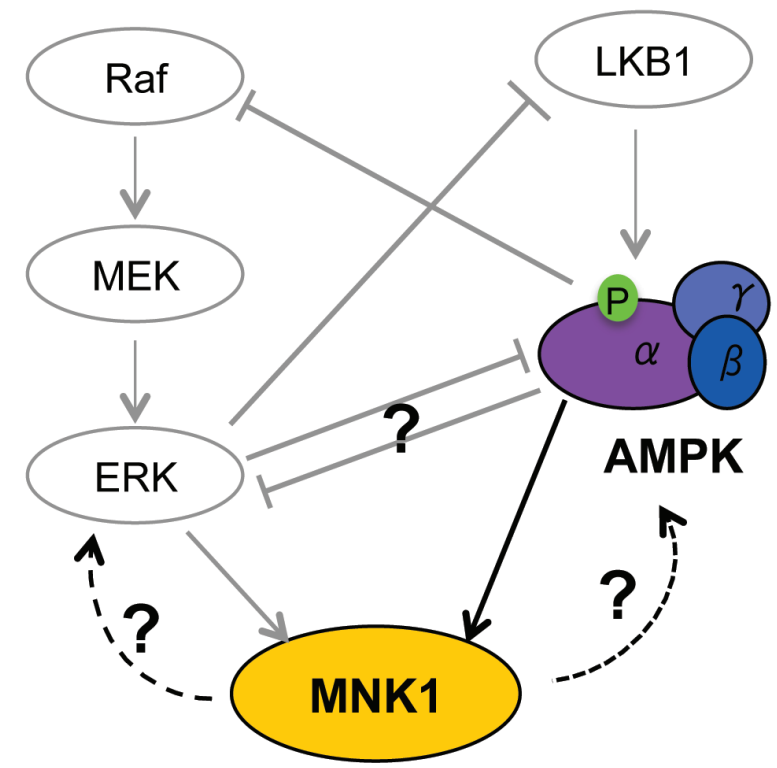

Figure 4. Inhibitory cross-talk of AMPK:ERK complex. Combined with data from this thesis, MNK1 activity is regulated by both Raf/MEK/ERK and LKB1/AMPK signaling pathways. ERK and AMPK showed inhibitory cross-talk. Though they are found in a complex, the cross-talk among ERK, AMPK and MNK1 remains unclear.

upstream kinase of MNK1a, can be activated by AMPK via recruitment to the scaffolding protein TAB1 $(28,29)$. Therefore, AMPK might also take effect on MNK1a-elF4E-translation via ERK-independent signaling, i.e., the P38 pathway. Clearly, a number of research questions can be formulated that are calling for further studies.

\section{(5) MNK1:AMPK:ERK complex in nucleus for transcription regulation}

In Chapter 5, we report that AMPK and MNK1 interact at the chromatin level and form a functional ternary complex with ERK in the nucleus. Although our observations do not provide an exact molecular understanding of these interactions yet, they are in line with earlier reports of MAPKAPK-family kinases taking part in a negative regulatory feedback mechanism to restrict the activity of M/SAPKs: our group previously reported a functional interaction between MK3, ERK/P38 and Polycomb Group transcriptional regulators that controls e.g. Atf3 expression (30); here we show that MNK1a regulates AMPK:ERK association with chromatin. In the context of Egr1 gene expression, the reduced basal Egr1 mRNA levels in $\mathrm{AMPK}^{\mathrm{dKO}}$ and MNK1 $\mathrm{a}^{\mathrm{KD}}$ MEFs suggests that the presence of cellular AMPK or MNK1a act to maintain a steady-state level of Egr1 transcription. Alternatively, as AMPK (as well as MNK1a) is directly connected to mRNA translation, these differences may reflect an inability of AMPK deficient cells to maintain an appropriate translational response as a result of altered cellular physiology. Future 
studies employing specific defective interaction and/or cell compartment-restricted mutant protein forms may provide additional insight in the co-regulation of these cellular processes. It should be noted that the AMPKa1-KO model still expressed an AMPK $\alpha 1$ which lacks a functional kinase domain. Hence it is currently not clear whether at the level of chromatin, its physical presence affects transcription (in analogy to what has been reported for MAPKAPKs in this and other studies $(30,31)$ ). In the context of MNK1a chromatin-binding, these findings may point out that nuclear shuttling of MNK1a governs compartmentalization of its function and that MNK1a is retained in cytoplasm via a cytoplasmic binding partner, e.g. elF4G. As a future perspective, comparison of MNK1a WT and NLSyn mutant (mainly in nucleus) in fractionation and immunoprecipitation assays would be informative to test this hypothesis. It is conceivable that the functional tripartite interaction (phosphorylation) of AMPK, M/SAPKs and MNK1a determines their subcellular localization and thereby their availability to participate in defined cellular processes. Definition of interaction domains and full complement of deletion and phosphor-mutant analysis should be able to address this idea. In addition, exploring molecular mechanisms at the chromatin level requires definition of gene targets. Our current efforts aim at identification of potential direct targets of EGR1 in the context of metabolic stress, using high-throughput gene expression analysis. Chromatin immunoprecipitation assays providing evidence for the (combined) presence of ERK, EGR1, AMPK and MNK1a at such potential target genes would certainly determine their roles in transcriptional regulation.

\section{Concluding remarks}

The two main subjects of this study are AMPK and MNK1a. AMPK activators are considered as treatment strategies in various metabolic diseases and cancer, and $\mathrm{MNK} 1 / 2$ is widely being investigated as a cancer therapy target for its regulation of elF4E phosphorylation. This thesis links both kinases with the discovery of a new AMPK-MNK1a signaling axis, by studying the molecular consequences of its activation, and by investigating its potential effect in the context stress-induced regulation of translation and transcription. With still a long way ahead in regard to elucidation of the biochemical and biological consequences of this interaction, identification of specific bindingpartners, signaling targets and pathways involved, the current thesis holds promise for both improved understanding of and ultimate application of this knowledge in human pathological conditions, especially in cancer, where AMPK and MNK1 previously had their independent stand. Namely, the finding that AMPK augments MNK1a activity towards elF4E, which is contrary to MNK1/2 inhibition as anti-cancer strategy, bears obvious relevance for the cancer field. 


\section{References}

1. Hardie, D. G., Ross, F. A., and Hawley, S. A. (2012) Nat Rev Mol Cell Biol 13, 251-262

2. Mihaylova, M. M., and Shaw, R. J. (2011) Nat Cell Biol 13, 1016-1023

3. Gebauer, F., and Hentze, M. W. (2004) Nat Rev Mol Cell Biol 5, 827-835

4. Waskiewicz, A. J., Johnson, J. C., Penn, B., Mahalingam, M., Kimball, S. R., and Cooper, J. A. (1999) Mol Cell Biol 19, 1871-1880

5. Raught, B., and Gingras, A. C. (1999) Int J Biochem Cell Biol 31, 43-57

6. Sonenberg, N., and Gingras, A. C. (1998) Current opinion in cell biology 10, 268-275

7. Motoshima, H., Goldstein, B. J., Igata, M., and Araki, E. (2006) J Physiol 574, 63-71

8. Diab, S., Kumarasiri, M., Yu, M., Teo, T., Proud, C., Milne, R., and Wang, S. (2014) Chem Biol 21, 441-452

9. Graff, J. R., Konicek, B. W., Carter, J. H., and Marcusson, E. G. (2008) Cancer Res 68, 631-634

10. De Benedetti, A., and Graff, J. R. (2004) Oncogene 23, 3189-3199

11. Ueda, T., Watanabe-Fukunaga, R., Fukuyama, H., Nagata, S., and Fukunaga, R. (2004) Mol Cell Biol 24, 6539-6549

12. Gorentla, B. K., Krishna, S., Shin, J., Inoue, M., Shinohara, M. L., Grayson, J. M., Fukunaga, R., and Zhong, X. P. (2013) J Immunol 190, 10261037

13. Chrestensen, C. A., Eschenroeder, A., Ross, W. G., Ueda, T., Watanabe-Fukunaga, R., Fukunaga, R., and Sturgill, T. W. (2007) Genes Cells 12, 1133-1140

14. Ueda, T., Sasaki, M., Elia, A. J., Chio, II, Hamada, K., Fukunaga, R., and Mak, T. W. (2010) Proceedings of the National Academy of Sciences of the United States of America 107, 13984-13990

15. Wheater, M. J., Johnson, P. W., and Blaydes, J. P. (2010) Cancer Biol Ther 10, 728-735

16. Ramalingam, S., Gediya, L., Kwegyir-Afful, A. K., Ramamurthy, V. P., Purushottamachar, P., Mbatia, H., and Njar, V. C. (2014) Oncotarget 5, 530-543

17. Reiling, J. H., Doepfner, K. T., Hafen, E., and Stocker, H. (2005) Curr Biol 15, 24-30

18. O'Loghlen, A., Gonzalez, V. M., Jurado, T., Salinas, M., and Martin, M. E. (2007) Biochim Biophys Acta 1773, 1416-1427
19. Goto, S., Yao, Z., and Proud, C. G. (2009) Biochem J 423, 279-290

20. Hou, J., Teo, T., Sykes, M. J., and Wang, S. (2013) ACS Med Chem Lett 4, 736-741

21. Du, J., Guan, T., Zhang, H., Xia, Y., Liu, F., and Zhang, Y. (2008) Biochem Biophys Res Commun 368, 402-407

22. Lopez-Cotarelo, P., Escribano-Diaz, C., GonzalezBethencourt, I. L., Gomez-Moreira, C., Deguiz, M. L., Torres-Bacete, J., Gomez-Cabanas, L., Fernandez-Barrera, J., Delgado-Martin, C., Mellado, M., Regueiro, J. R., Miranda-Carus, M. E., and Rodriguez-Fernandez, J. L. (2015) J Biol Chem 290, 827-840

23. Hwang, S. L., Jeong, Y. T., Li, X., Kim, Y. D., Lu, Y., Chang, Y. C., Lee, I. K., and Chang, H. W. (2013) BrJ Pharmacol 169, 69-81

24. Damm, E., Buech, T. R., Gudermann, T., and Breit, A. (2012) Mol Endocrinol 26, 643-654

25. Kawashima, I., Mitsumori, T., Nozaki, Y., Yamamoto, T., Shobu-Sueki, Y., Nakajima, K., and Kirito, K. (2015) Exp Hematol 43, 524-533 e521

26. Kim, M. J., Park, I. J., Yun, H., Kang, I., Choe, W., Kim, S. S., and Ha, J. (2010) J Biol Chem 285, 14617-14627

27. Martin, M., and Marais, R. (2013) Mol Cell 52, 155-156

28. Lanna, A., Henson, S. M., Escors, D., and Akbar, A. N. (2014) Nat Immunol 15, 965-972

29. Li, J., Miller, E. J., Ninomiya-Tsuji, J., Russell, R. R., 3rd, and Young, L. H. (2005) Circ Res 97, 872879

30. Prickaerts, P., Niessen, H. E., Mouchel-Vielh, E., Dahlmans, V. E., van den Akker, G. G., Geijselaers, C., Adriaens, M. E., Spaapen, F., Takihara, Y., Rapp, U. R., Peronnet, F., and Voncken, J. W. (2012) Epigenetics Chromatin 5, 12

31. Ronkina, N., Kotlyarov, A., Dittrich-Breiholz, O., Kracht, M., Hitti, E., Milarski, K., Askew, R., Marusic, S., Lin, L. L., Gaestel, M., and Telliez, J. B. (2007) Mol Cell Biol 27, 170-181 


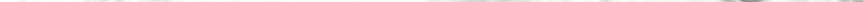




\title{
Appendices
}

\author{
Summary \\ Samenvatting \\ 总结 \\ Valorization \\ Curriculum vitae \\ Acknowledgments
}




\section{Summary}

Cell energy balance is tightly regulated by AMPK, which becomes activated to increase energy production and inhibit energy-consuming processes. Based on this crucial role, AMPK has been intensively studied as a signaling-hub controlling both cell growth and metabolism. MNK1 emerged from a screening for novel AMPK substrates. MNK1 stands out as a known regulator of mRNA translation and therefore its potential functional connection to AMPK was comprehensively investigated in this thesis, entitled "The AMPK-MNK1 signaling axis".

Upon phosphorylation by upstream kinases and stimulated by allosteric activators, AMPK adjusts energy balance via enhancing catabolism of (stored) fuels (e.g. glucose/ fatty acid uptake, oxidation) and inhibiting anabolic processes (e.g. glycogen synthesis, storage). However, the exact role of AMPK in cell growth and survival is presently under discussion. We have identified a potential novel AMPK-target in this thesis, MNK1, a well-known regulator of the translation initiator factor $4 \mathrm{E}$ (eIF4E) and therefore an interesting cancer therapy target. Thus, a general introduction focused on the two key players in the thesis: AMPK and MNK1 (Chapter 1).

In order to investigate and reveal diverse roles of AMPK in various diseases, different study methods have been developed. As a summary for in vitro study, methodological insights into production of AMPK as a heterotrimeric protein, its biochemical characterization and cellular signaling studies were included in this thesis (Chapter 2). Notably, a workflow was described that specifies the necessary steps for novel AMPKtarget identification and their validation in cell-free and cellular systems.

Using the protocol above, MNK1a was identified as a target of AMPK both in in vitro kinase assays and in the cellular environment (Chapter 3). MNK1a serine 353 (S353) was identified as the target phospho-site and its phosphorylation was facilitated by prior T-loop activation. In cells, MNK1a was found to be a physical binding partner of AMPK and the functional modification of MNK1a at S353 turned out to enhance its kinase activity toward eIF4E phosphorylation. These findings describe a novel signaling branch of AMPK in mRNA translation and cell growth control.

The function of AMPK-mediated MNK1a-S353 phosphorylation in cell proliferation was then investigated (Chapter 4 ). In this regard it is important to note that the functional consequences of elF4E phosphorylation for translational initiation as yet have not been clarified. Although a rate-limiting factor in translation initiation, upregulation of elF4E phosphorylation by over-expression of MNK1a ${ }^{\text {S353D }}$ (a phosphorylation-mimicking mutant) did not conclusively show induction of global mRNA translation compared to wild-type MNK1a. However, overexpression of MNK1 ${ }^{53530}$ increased the sensitivity of 
cells to rapamycin, as evidenced by lower growth rate. Conversely, MNK1a ${ }^{\mathrm{S} 353 \mathrm{D}}$ expression resulted in higher metabolic stress-resistance, reflected in decreased cell death rate under conditions of glucose deprivation. These data begin to identify AMPK-MNK1a signaling as a functional axis contributing to cell proliferation and survival control in response to stress. At the molecular level, we found that ERK regulates AMPK-mediated MNK1a phosphorylation and participates in the formation of stable ternary AMPKMNK1a-ERK complex.

The hitherto unknown chromatin-association of MNK1a and AMPK indicated their potential involvement in transcription regulation (Chapter 5). Nuclear abundance of MNK1a upon metabolic stress was found to mediate AMPK-chromatin binding, in which also ERK appears to play a regulatory role. Localization of proteins to chromatin often is associated with transcriptional control. AMPK-MNK1a regulated the basal immediate early EGR1 gene expression and both physically interacted with the EGR1 protein at the level of chromatin. Such EGR1 complexes may be involved in the regulation of the second phase of adaptive transcriptional responses or may be associated with transcriptioncoupled processes that govern adaptive responses.

Selected topics were finally discussed in relation to the main findings of this thesis (Chapter 6). The current knowledge of elF4E in cell growth control and the involvement of AMPK, MNK1 and mTOR were reviewed. The potential involvement of MNK1a in regulation of cell growth was explored in relation to its activation mechanism. Concerning the role of AMPK-MNK1 in signaling transduction, the inhibitory cross-talk between LKB1-AMPK and Raf-MEK-ERK was summarized as an extended remark. The potential of (co)transcriptional regulation was hypothesized for the AMPK-MNK1a-ERK complex in nucleus.

In conclusion, this thesis present a new AMPK signaling branch to MNK1a that controls cell division and growth and provides novel insights in MNK1a function that pave the way to further explore the regulatory mechanisms of gene transcription and mRNA translation. 


\section{Samenvatting}

De energie balans van een cel wordt strikt gereguleerd door AMPK, een eiwit dat, wanneer geactiveerd, de productie van energie verhoogt en energieverbruikende processen remt. Vanwege deze cruciale rol wordt AMPK intensief bestudeerd als een knooppunt van regulering van zowel celgroei als metabolisme. In een biochemische screening voor nieuwe AMPK substraten kwam MNK1a naar voren. Omdat MNK1 bekend staat als een regulator van mRNA translatie zijn potentieel functionele verbindingen met AMPK uitgebreid onderzocht in dit proefschrift, getiteld "The AMPKMNK1 signaling axis".

$\mathrm{Na}$ fosforylering door eerder geplaatste signaalkinases en gestimuleerd door allosterische activatoren, past AMPK de cellulaire energiebalans aan via het verhogen van afbraak van (opgeslagen) brandstoffen (bijv. opname en/of verbranding van glucose/ vetzuren ) en het remmen van anabolisme (bijv. glycogeen synthese, opslag). Echter, hoe exact AMPK celgroei en overleving reguleert is nog steeds onderwerp van veel discussie. We beschrijven een potentieel nieuw AMPK-target in dit proefschrift, MNK1, een bekende regulator van de translatie initiatie factor $4 \mathrm{E}$ (eIF4E) en daarom een interessant doelwit voor kankertherapie. In de algemene inleiding worden de huidige kennis over beide belangrijke spelers, AMPK en MNK1, beschreven (Hoofdstuk 1).

Om de diverse functies van AMPK in verschillende ziekten te onderzoeken en begrijpen zijn verschillende werkwijzen ontwikkeld. Bij wijze van samenvatting van in vitro onderzoeksmethoden, zijn inzichten in de productie van AMPK als een heterotrimeer eiwit, de biochemische karakterisering en cellulaire signalering ervan opgenomen in dit proefschrift (Hoofdstuk 2). Met name werd een workflow beschreven die de essentiele stappen voor identificatie van nieuwe AMPK-targets en hun validatie in cel-vrij en cellulaire systemen specificeert.

Gebruikmakend van een derrgelijk protocol werd MNK1a geïdentificeerd als een AMPK-target, zowel in in vitro kinase-assays als in cellulaire essays (Hoofdstuk 3). MNK1a serine 353 (S353) werd geïdentificeerd als het belangrijkste aminozuurresidue voor fosforylering door AMPK, die gefaciliteerd wordt door T-loop activering. In cellen blijkt MNK1a een fysieke bindingspartner van AMPK en de fosforylering van MNK1a-S353 bleek de kinase-activiteit van MKN1a richting elF4E te verhogen. Deze bevindingen beschrijven een nieuwe signaleringsas vanuit AMPK in de context van regulering van mRNA translatie en celgroei.

De functie van AMPK-gemedieerde MNK1a-S353 fosforylering in celproliferatie werd vervolgens onderzocht (Hoofdstuk 4). In dit verband is het belangrijk op te merken dat de functionele gevolgen van elF4E fosforylering voor translatie-initiatie nog niet geheel 
opgehelderd zijn. Ofschoon een snelheidsbeperkende stap in translatie-initiatie, lijkt toename van elF4E-fosforylering als gevolg van overexpressie van MNK1a ${ }^{\text {S353D }}$ (een mutatie die op fosforylering lijkt) vooralsnog niet overtuigend tot een hogere globale mRNA translatie te leiden vergeleken met wild-type MNK1a. Echter, overexpressie van MNK1a ${ }^{5353 D}$ verhoogde de gevoeligheid van cellen voor rapamycine, zoals blijkt uit verminderde celdeling. Omgekeerd resulteerde MNK1a ${ }^{5353 \mathrm{D}}$ expressie in een hogere metabole stressbestendigheid, hetgeen bleek uit een verminderde celsterfte onder omstandigheden waarin glucose beperkt was. Deze experimenten suggereren dat AMPK-MNK1a signalering als functionele as bijdraagt aan de regulering van celdeling en overleving onder stress. Op moleculair niveau bleek dat ERK AMPK-gemedieerde fosforylatie van MNK1a reguleert en deelneemt aan de vorming van een stabiel ternair AMPK-MNK1a-ERK complex.

De tot nog toe onbekende chromatine-associatie van MNK1a en AMPK duidt op hun mogelijke betrokkenheid bij transcriptionele regulering van genetische informatie (Hoofdstuk 5). Een toename van MNK1a in de celkern in reactie op metabole stress bleek AMPK-chromatine binding tot stand te brengen, waarbij ook ERK een regulerende rol lijkt spelen. Binding van eiwitten met chromatine is vaak geassocieerd met transcriptionele controle. AMPK-MNK1a regelde de basale expressie van het immediate early gnene EGR1 en beide laten een fysieke interactie met het EGR1 eiwit op chromatineniveau zien. Dergelijke complexen zouden betrokken kunnen zijn bij de regulatie van de tweede (late) fase van een adaptieve transcriptionele respons of zou geassocieerd kunnen zijn met transcriptie-gekoppelde processen die adaptieve responsen regelen.

Een aantal geselecteerde onderwerpen werd uiteindelijk besproken met betrekking tot de belangrijkste bevindingen in dit proefschrift (Hoofdstuk 6). De huidige kennis van elF4E in de regulering van celdeling en -groei en de betrokkenheid van AMPK, MNK1a en mTOR zijn hierin uiteengezet. De mogelijke betrokkenheid van MNK1a bij de regulatie van celgroei in relatie tot het moleculaire activeringsmechanisme is belicht. De rol van AMPK-MNK1 in cellulaire signaaloverdracht is uitgebreid besproken in de context van de remmende regulering tussen LKB1-AMPK en Raf-MEK-ERK. Dit hoofdstuk sluit af met de hypothese dat het AMPK-MNK1a-ERK complex in de kern betrokken is bij (co) transcriptioneel regulerende processes.

Tot slot, dit proefschrift presenteert een nieuwe AMPK signalerings as naar MNK1a die celdeling en -groei regelt en levert hiermee nieuwe inzichten op met betrekking tot de functie van MNK1a; deze inzichten zullen bijdragen aan het verder onderzoeken en ophelderen van regulerende mechanismen van gen transcriptie en mRNA translatie. 


\section{总结}

AMP 依赖的蛋白激酶（AMPK），是生物能量代谢调节的关键因子; 其在激活 状态下可提高能量生成, 同时抑制能量消耗。基于此作用机制, AMPK已作为控 制细胞生长和代谢过程的信号中心被广泛研究。在对AMPK下游目标蛋白的笁选 中，蛋白芯片技术显示MAP激酶相互作用的丝氨酸/苏氨酸激酶1（MNK1）是 AMPK的磷酸化目标。作为已知的mRNA翻译调节器, 本课题对MNK1与AMPK的相 互作用进行了研究, 即“AMPK-MNK1信号通路”。

在上游蛋白激酶的磷酸化激活或者变构激活剂的刺激下, AMPK可调节能 量代谢平衡, 主要通过提高 (存储) 能量的催化利用（如葡萄糖/脂肪酸摄取 和氧化），以及抑制能量合成代谢（如糖原合成和储存），而目前AMPK在细 胞生长及存活中的确切作用仍未有定论。本论文中, 我们笁选出MNK1是一个 潜在的AMPK下游蛋白酶, 其因调节翻译起始因子 $4 E(e I F 4 E)$ 而成为了癌症治疗 靶标。因此, 本论文第一章对两个研究对象AMPK和MNK1分别进行了概括介 绍。

为了揭示AMPK在各种疾病中的角色, 很多不同的研究方法已被开发出来。本 论文第二章, 通过三个方面（异源三聚体蛋白AMPK的纯化、生化特征探索以及 细胞信号通路)，对AMPK体外学习方法进行了系统的总结。值得注意的是，本 章对鉴定AMPK目标蛋白以及利用体外和细胞系统识别并验证该目标的工作流程 进行了详尽的描述。

利用上述流程，本论文第三章利用体外酶反应以及细胞信号系统对MNK1a 作 为AMPK下游目标蛋白进行了集中验证。MNK1a氨基酸结构中, 第353位的丝氨酸 (S353)被确认为AMPK磷酸化作用位点, 并且该磷酸化作用是在MNK1a苏氨酸活化 基础上发生的。同时，在细胞体系实验中，MNK1a是AMPK的结合蛋白，而且其 介导的S353磷酸化可提高MNK1a酶活性, 从而导致elF4E磷酸化水平的升高。这些 发现提供了AMPK信号通路在mRNA蛋白翻译以及细胞生长控制过程中的一个新分 支。

论文第四章对MNK1a S353磷酸化在细胞增殖过程中的作用进行了探索。在 此, 需要注意的是eIF4E的磷酸化在蛋白翻译起始中的作用至今并未被揭示清楚。 本章中, 与野生基因型过表达的细胞系相比, 尽管 MNK1a S353D基因突变型的过 表达升高了作为翻译限速因子的eIF4E的磷酸化水平, 细胞系的整体蛋白翻译水平 并未有变化。然而, MNK1a S353D基因突变型的过表达提升了细胞对rapamycin的 敏感性, 具体表现为细胞生长速率的降低; 相反的是, 在葡萄糖缺失的压力条件 下，S353D基因突变型的过表达降低了细胞死亡率，体现了较好的代谢应激能 力。这些数据体现了AMPK-MNK1信号通路在细胞增殖和存活控制过程中的作用。 同时在分子水平，我们发现上游蛋白激酶ERK参与调控AMPK介导的MNK1a磷酸 化, 并且三者可形成稳定的蛋白复合体。 
论文第五章重点分析了位于染色体上的AMPK和MNK1a在基因转录调控过程中 的潜在作用。我们发现细胞核中MNK1a 的增多降低了AMPK在染色体上的分布, 同时ERK也参与其中。由于蛋白在细胞核内的分布通常与其对转录的调控有关, 在本章中我们发现, AMPK-MNK1a调控立早基因 EGR1的基本转录水平, 并且三者 在染色体水平上发生共沉，而这样的EGR1蛋白复合体有可能参与应激反应后期适 应性转录水平的调控, 或者是与调控适应性反应相耦合的转录水平控制有关。

论文第六章通过结合论文中的新发现，对几个相关问题进行了深入的讨论：我 们总结了 eIF4E在细胞增殖过程中的作用, 以及AMPK、MNK1a和 mTOR的参与作 用; 也对 MNK1a的激活机制和其对细胞生长的调控进行了探讨。对于AMPKMNK1a在信号传导中的角色，我们也对LKB1-AMPK和Raf-MEK-ERK之间的相互抑制 作用进行了拓展讨论, 并且分析了 AMPK - MNK1a -ERK复合体在转录共调控中的可 能作用。

总之, 本文展示了AMPK-MNK1a作为一条新的信号分支在细胞分裂生长过程中 的调控, 并且对MNK1a功能的探索也为揭示其对基因转录和mRNA翻译的调控奠 定了基础。 


\section{Valorization}

In addition to the scientific relevance of this thesis, the presented work uncovered a new research area that could offer leads for future therapeutic strategy development and thus carries promising societal relevance.

\section{Social relevance of the study objectives}

Modern worldwide economic development has induced dramatic changes in lifestyle and the Metabolic syndrome has become one of the biggest threats for healthy living. The Metabolic syndrome is a cluster of the most prominent heart disease risk factors, including diabetes and obesity, which has a prevalence of $20-25 \%$ in adults worldwide. Diabetes itself has become a top cause of death in developed countries. Logically, the burden on healthcare systems is rising dramatically and the cost of treatment is enormous [1].

Due to its crucial role in energy-balance, AMPK is a highly valuable pharmacological target in the treatment of metabolic disorders. However, at present only a subset of AMPK functions and substrates have been elucidated. By revealing more downstream targets of AMPK, a more complete functional map could be obtained, which could potentially offer various possibilities for prevention of disease development, or specific treatment options for certain risk factors. Regarding MNK1 function, most recently a novel role of MNKs has been reported in mediating HFD-induced insulin resistance [2], in light of the discoveries described in this thesis, this could represent a new hidden therapeutic connection with AMPK.

Similarly, as one of the other leading causes of morbidity and mortality worldwide, cancers in 2012 reached approximately 14 million new cases and 8.2 million deaths [3]. The survival rate of divers cancers are known to vary among types and stages and they range between disease-free survival to mortality within five years after diagnose. More strikingly, although several treatment methods have been developed for cancer therapy, the long-term side effects of these methods are almost as destructive to a patients' health as the disease itself, both physically and mentally. As a result, research in the field of cancer therapy, focusses on identification of underlying molecular mechanisms in individual cases and defining personalized approaches. Thus far, the exact role of AMPK in cancer remains unclear due to its two-faced involvement: several tumor types have been observed with loss of AMPK activity, while AMPK activation may be advantageous for other tumors cells to adapt to metabolic stress [4]. In contrast, high elF4E expression has been found in many tumor cell lines and even in solid tumors, including cancers of breast, lung, prostate and colon [5]. As the sole-known upstream kinase of elF4E, MNKs have therefore been treated as cancer therapy targets and have also been associated to 
drug resistance. In this thesis we aimed to determine a potential connection between AMPK and MNK1 to understanding their functional relationship in cell growth control and to advance insight in their potential application in cancer treatment.

\section{Novelty of the concept}

Current knowledge of MNK1 as a therapeutic target in cancer is limited to its regulation on elF4E phosphorylation in response to both growth factors and stress via ERK/P38. Yet, relatively little is known concerning the exact mechanisms of its activation and functional regulation. In this thesis, we further developed a probable MNK1 activation model based on earlier reported structural models. We described its localization to both cytoplasm and nuclei, potentially revealing a role on both translational and transcriptional processes. The novel link of MNK1 to AMPK may be interpreted as evidence for its potential involvement in metabolic disorders. The results thus far showed a non-linear correlation between them elF4E activity and cellular translation level, implying a more delicate/selective control of elF4E in protein translation. From the perspective of AMPK, the novel connection to regulation of MNK1 activity has extended its role in protein translation, which previously comprised the mTOR signaling pathway. These observations may be at the basis of AMPKs dual role in cell proliferation, growth control and cancer.

\section{Future directions \& potential applications}

The extended knowledge of MNK1 in this thesis could be applied to related studies of both MNK1 structure analysis and MNK1-dependent signaling pathways. Several studies have indicated that location matters: subcellular compartmentalization of particular proteins restricts molecular interactions and dictates function and regulation. This concept applies to AMPK as well as MNK1, as both appear to "shuttle" between the cytoplasm and the nucleus. Future studies should be aimed at further elucidation of the biological relevance of AMPK and MNKs subcellular localization.

Beyond the directions above, this study has proven the protein microarray screening as an efficient and accurate technology and this method shows high potential for a broad application of substrate-screening for other protein kinases. In addition, the novel antibody we have generated in this study, has been proven to be effective in detection of a specific activity state of MNK1, and is expected to improve our knowledge on the exact conditions, mechanisms and relevance of MNK1a regulation. Given the observation that many more post-translationally modified, potentially regulatory amino acid residues await identification, both in AMPK and MNK, this holds promise for research as well as marketing avenues. 
1. The IDF consensus worldwide definition of the metabolic syndrome. International Diabetes Federation, 2006.

2. C. E. J. Moore, J. Pickford, F. R. Cagampang, R. L. Stead, S. Tian, X. Zhao, X. Tang, C. D. Byrne\& C. G. Proud. MNK1 and MNK2 mediate adverse effects of high-fat feeding in distinct ways. Scientific Reports 6, Article number: 23476 (2016)

3. http://www.who.int/mediacentre/factsheets/fs297/en/

4. Faubert, B., Vincent, E. E., Poffenberger, M. C., Jones R. G..The AMP-activated protein kinase (AMPK) and cancer: Many faces of a metabolic regulator. Cancer Letters (2015)

5. Yaël Mamane, Emmanuel Petroulakis, Liwei Rong, Kaori Yoshida, Lian Wee Ler and Nahum Sonenberg. elF4E - from translation to transformation. Oncogene (2004) 


\section{Curriculum Vitae}

Xiaoqing Zhu was born on the 13th of May, 1987 in Shandong, China. After completion of high school in her hometown, she was accepted by Beijing University of Chinese Medicine (BUCM) in 2006 and there she joined in a six-year program for a combination of Bachelor and Master study without further examination. In the first four years of Bachelor study (2006-2010), she accomplished different courses regarding Chinese Medicine, molecular biology and pharmaceutical engineering. With excellent study achievements, she got National scholarships twice and University scholarship once. In 2008, she was selected as an excellent volunteer of Beijing Olympic Games. In 2010, she started her master study with Master student Scholarship in the department of Molecular Pharmacognosy, BUCM. In this period, she participated in the project "The source investigation of Clematis terniflora var. mandshurica in Northeastern China" and accomplished her master thesis in the project of "The Copy Number Variations (CNVs) construction of genes in glycyrrhizin production process (HMGR, SQS, $\beta$-AS) in Pichia bacteria" in 2012. In the same year, she started as a PhD candidate in the department of Molecular Genetics, Maastricht University, the Netherlands. She studied under close supervision of Dr. Dietbert Neumann and Dr. J. Willem Voncken and was supported by the Chinese Scholarship Council for four years (2012.09-2016.09). 


\section{Publications}

1. Xiaoqing Zhu, Vivian Dahlmans, Ramon Thali, Christian Preisinger, Benoit Viollet, J. Willem Voncken, Dietbert Neumann. (2016) AMP-activated protein kinase upregulates MAP kinase interacting serine/threonine kinase 1a-dependent phosphorylation of eukaryotic translation initiation factor 4E. Journal of Biological Chemistry.

2. Xiaoqing Zhu, J. Willem Voncken, Dietbert Neumann. (2016) In vitro methods to study AMPK. Book title: "AMP-activated protein kinase", Ed. M. Cordero and B. Viollet. Book series: Experientia Supplementum. Springer. ISBN 978-3-319-43589-3.

3. Ying Liu, Xiaoqing Zhu, Wendong Li, Hao Wen, Ya Gao, Yong Liu, Chunsheng Liu. Enhancing production of ergosterol in Pichia pastoris GS115 by over-expression of 3-hydroxy-3-methylglutaryl CoA reductase from Glycyrrhiza uralensis[J]. Acta Pharmaceutica Sinica B, 2014, 4(2): 161-166.

4. Mohammad M. Al-bataineh, Hui Li, Kazuhiro Ohmi, Fan Gong, Allison L. Marciszyn, Sajid Naveed, Xiaoqing Zhu, Dietbert Neumann, Qi Wu, Lei Cheng, Robert A. Fenton, Nuria M. Pastor-Soler, and Kenneth R. Hallows. Acute Activation of the Metabolic Sensor AMP-Activated Protein Kinase Inhibits Aquaporin-2 Function in Kidney Principal Cells. (Accepted by American Journal of Physiology - Renal Physiology)

5. Marie Miglianico, Yvonne Oligschlaeger, Dipanjan Chanda, Kanin Wichapong, Will A Coumans, Armand Jaminon, Ricardo Rodriguez-Calvo, Özge D Özcete, Roy Schrijver, Xiaoqing Zhu, Ivo Bleylevens, Nynke MS van den Akker, Daniel GM Molin, Jan FC Glatz, Gerry AF Nicolaes, Dietbert Neumann. Pharmacological targeting of the AMPK carbohydrate-binding pocket. (Submitted)

6. Dipanjan Chanda, Yvonne Oligschlaeger, Yilin Liu, Xiaoqing Zhu, Jieyi Li, Marie Miglianico, Will Coumans, Joost J.F.P. Luiken, Jan F.C. Glatz, Dietbert Neumann. 2-Arachidonoylglycerol reverses inflammation-induced insulin resistance in cardiomyocytes. (Submitted) 


\section{Scientific activities}

2016.03

2015.10

2015.09

2015.04

2014.09

2013.09

2013.03

Plenary Meeting-Department of Genetics \& Cell Biology, Maastricht, The Netherlands

Pitch presentation

Maastricht -Nijmegen Science day, Nijmegen, The Netherlands Pitch presentation

2nd European AMPK workshop, Maastricht, The Netherlands Co-organizer \& Oral presentation \& Poster presentation Genetic Retreat, Kerkrade, The Netherlands Oral presentation

$$
\text { FASEB conference, Lucca, Italy }
$$

AMPK: Biological action and therapeutic perspectives 1st European AMPK workshop, Maastricht, The Netherlands Genetic Retreat, Kerkrade, The Netherlands 


\section{Acknowledgement}

It is tacky to say that time flies, but it is. Now, four-year study has come to an end and a closure seems to be necessary. I have to say my life was great in Maastricht with wonderful memories and some regrets as well. Maastricht, with an awkward name in Chinese (马斯特里赫特), is a place beyond all my expectations with enjoyable weather (better if with less rain), beautiful scenes and warm-hearted people. These four years is a crucial part in my 29-year life and I really appreciate all the nice people I know here, because all of you enriched my life, a better life I believe.

First my appreciation goes to my promoter-Prof. Jan Glatz. Dear Jan, I still remember how excited I was when I got your email introducing me to Willem. I appreciated your help so much. And then it turned out that you are such a nice "boss" of the department with smiles and easy-going personality in these four important years for me. Jan, thanks a lot to your great help and I had a good time in Molecular Genetics.

Next, the most important people in these four years, with whom I talked almost every week-everyday, about the project, about opinions of both Europe and China, about life... my dearest supervisors Dr. Neumann and Dr. Voncken. Here I guess you two probably are smiling or laughing to read my words and thinking that Xiaoqing is still too serious/nervous to call us like this. But as always, it contains respect, appreciation and also fun.

Willem, dear Willem! My first impression of you is from the picture hanging on the wall of the library and actually I like it very much, though you do not. In the first meeting we had, you started with a story that Chinese people were saying "yes" all the time, then you stopped and looked in to my eyes. I remembered at that moment I replied "yes" and everyone laughed. It was a funny beginning and it also became a great reminder to me whenever I need to say yes to you or others. In the first two years, I have to admit that I had a hard time when I felt a bit overwhelmed by your knowledge, your interpretation and your fast mind. But I felt very free to talk with you about all my feelings and you were also always there to explain from a basic concept or even a word. As you told me every time I "cried", I improved a lot even without noticing myself, but I do know it is because of you! Soon, I learned to say "no", sometimes in a very direct/rude way. Though you said you liked it, I know I became a bit tricky to deal with. But still, like a father, you kept calm, listened and talked. When I recalled this part in my memory, tears are always full of my eyes. Willem, thank you very much for taking me as your student and I do believe it is an honor. Also, I do hope that I left an impression of a "qualified" student to you. Willem, do you remember, every time I went back to China, you would tease and ask "are you still coming back"? Unfortunately, this time the answer is "no", for near future at least. To make it less sad, I want to let you know that I will take what I have learned 
from you with me for a longer and more confident journey and I am always sending my best wishes to you wherever I will be.

Dietbert, I always wanted but did not make it to tell you that you are the nicest supervisor/boss/friend I would like to work with and continue to work for, which I hope Willem will not be jealous on. As I told for thousands of times, the scene we first met in front of the information desk was an unforgettable experience forever: when I was staring at Willem's photo, you stood behind and gently said "hi" with your hand in the air for me and your super handsome smile. It not only drove away the tiredness and nervousness completely, but also implanted a super good impression of Germans in my mind. I was also very touched when you talked with me seriously about my problems of working on weekend and that you said I should let you know if I was unhappy. I think I even wrote a blog to appreciate that. The other day you sent me home after a late party and told me that you feel it is your responsibility to keep me safe home. You know how precious it is for a student living abroad himself/herself?! All in all, in these four years, we had great times with our group in dinners, bars, trips, workshops and ceremonies. Dietbert, thanks a lot for letting me feel very welcomed here and also learned me a lot in both science and life. Thanks for sharing with me a lot with easy and direct talks. Thanks for always being there with smiles and listening. With you, I saw a good scientist with kindness, patience, openness and respect all the time, a person whom I want to be myself. It is time to say goodbye, but I do believe our "friendship/supervisor-studentship" never ends. At last, beyond my best wishes to you, your wife and your lovely twins, I invite you to have a trip in China and I will be for sure your guide. LOOK FORWARD TO THAT DAY!

The greatest hug next goes to another great person-Vivian, my paranymph, who "walked" along with me and offered her super power into this project. Literally, I cannot imagine how it would end without you. Vivian, you are a great helper in the lab, but more than that, you made me feel very warm to work with you, talk with you and share with you. Thanks for sharing your lifestory with me and I like to hear them far beyond than science only; thanks for being my paranymph and I actually feel honored to have you there; thanks for knowing me with the great lavender and I do get the smell of southern France; thanks for listening to me and cheering me up with good suggestions all the time. I feel we two formed such a good team in cell culturing, cloning and so on. How lucky I am! Vivian, you are the warm person for my life in Maastricht whenever I think of and I hope this is the best way for you to get my grateful feeling. Please also send my best wishes to your husband and kids! Wish you all the best!

Within and beyond this project, I have also gotten several "sisters" and "brothers" with whom I had all the best memories: 
Sweet Marie, our young sister, at the beginning you used your wonderful experience and openness to embrace me into this unfamiliar place, though it was also new for you; it turned out later that I am so willing to share with you every thought I had, every joke I made and every story I got, and of course also listen to your suggestions, rules and life interests; in the fourth year though you left here, I felt we even walker further with our friendship by greetings, cheers and meetings; I am so happy to see your progress in getting your new job, a great one I am sure and I know we will go for lifetime as sisters! Marie, keep in touch and I will be always there for you. Hugs!

Hey Yvonne, our beautiful sister, thank you the most for helping me in the lab by teaching and telling all the techniques in great details; thank you for always being patient in Dutch translations; thank you for all the great help in my life in Maastricht! I am happy for you with a new and relaxing life! Good luck!

Dip, brother No.1, we did not talk casually that much, but I do remember all the novel/same ideas I have learned from you! And it was a great time our group had in Italy, FASEB conference. You treated me with "expensive" drinks there and took me along in the social event. Honestly, I like talking with you very much since both of us can be open, direct and "brutal"! I admire your cleverness and I am sure you will be a great group leader soon. J

Hey, hey, hey, Ricardo bro!!!!!! Smiles are always on our faces when Yilin and I talked about you. I missed your great cooking and our walk nearby; I missed all your jokes and kindness; I missed your hard-working together with us! Ricardo, Yilin always pictured you as the Winnie the Pooh and I think it is the best picture I had for you as well: warm, cute and caring. I like to hear you call me "sister" and I am glad that you are enjoying a lot together with Marta and around your parents. Hope we can manage to meet in Barcelona!!!

Next greetings go to my students: Daphne, thanks for being my first student when I was not sure about myself and thanks for sharing your great feeling about my tutoring; it was a pleasure to work with you and good luck! Milou, you are such an excellent student with pressure on me, but I took it as very positive power I got from you, who are always full of passion for both science and life; I miss your chocolate pie a lot and hope I can have a taste once more!!! Ben, I think you came into this project just in the perfect timing and offered your expertise in data analysis which I appreciated very much; I am glad that we can talk about everything and also had great dinners over Chinese food and Mahjong game!!!

In the Department of Molecular Genetics, I met nice group leaders and also their great group members.

Joost, do you still have the chocolate medal we got together? It was a great time as 
a group in the latest labuitje and you brought so much fun which made that day wonderful. I wish you all the best with your beloved CD36 research and also climbing!!!

Ronit, you are an amazing woman with great charm as a group leader and of course professor; your great life story also inspired me a lot! Wish you and your families had a good time in China! And I do feel the honor to have you as the chairman of my thesis committee. Thanks a lot!

Ilvy and Amber, it was great to meet you in the last year of my study and got great talks and fun in our games and dinner!!! Tim, congratulations on your marriage with your model-girlfriend; Sofie, thanks for always sharing entertainment information with us and good luck on your tennis training; Mike and Albert, look forward to good news with your career; Tom, enjoy your last year of study and wish you can achieve your goal, of course thanks a lot for offering your car many times; Miranda, best wishes on your papers! Will and Patrick, I appreciated your help a lot in the lab; Marion, thanks a lot for your tea leaves and still no idea what I should send to you as a gift! Petra and Henny, your great and kind help is highly appreciated during my study, in both small and big occasions and you always have my best wishes. Hanneke, I had a great time working with you in organizing AMPK-workshop and thank you! All in all, together with Yeliz, Guus, Peggy and Emiel, I have gotten through a lot of happy moments in parties, funparks and labuitjes with you guys and thanks to everyone!!!

I also got great help from nice people of other departments: Minh, you always gave me support for everything and I am very touched; good luck on your project! Mieke, I was amazed by your interest in Chinese culture and we had so much to talk about; next time when you are in Qingdao, remember to contact me and we will do Tai Chi together! Dr. Christian from Aachen, though we did not meet that much, I am so thankful for your great work in MS analysis for us! Dr. Ramon, thanks for offering your precious suggestion to my project! Dr. Tim and Andy, your kind help made me finish the thesis well and I appreciated it so much! Miriam, you are such a warm-hearted lady and best wishes to you! Ivo and Tom, I had a good time with you in the Genetic retreat and hope both of you a happy life!

Except for a new and different work-life here, this project also brought me a lot of good friends who have decorated a colorful journey for my social life!

Nadine, my first Dutch friend, how are you? It is a wonderful feeling that we have our birthday on the same day and we became friends! We talked a lot in my small room and cooked together of Lasagna for the first time in my life. I was glad that you invited me to join in a visit to your boyfriend in Sittard. The moment you told me that you two were about to settle down with your own house, I was very happy for you! I sincerely hope you are with all the happiness now and I want to visit you soon, if you do not mind my 


\section{missing after a hard year!}

婕一和俊芳, 感谢你们多次的款待, 为你们的幸福祝贺, 也被你们的甜蜜感 染，对人生充满希望，当然最感激的是我们点缀了彼此的无聊生活，有麻将三国 杀还有火锅, 最后祝你们一切顺顺利利吧; 张硕, 感谢你和小安的招待, 以及时 常带给我新鲜感的各种想法, 室内攀岩时感谢你的带领和帮助, 想祝福你完成一 切人生计划, 期待你们的好消息; 华仔和徐青, 虽然认识时间不长, 但也度过了 一些欢乐的游戏聚餐时光, 祝你们好运, 无论生活还是工作。倩儿, 我们见面机 会不多, 但是每次你来或者我往, 都让我觉得像是异国他乡亲人一般的存在, 感 谢你不时的鼓励和慰问, 总带给我正能量, 我衷心希望朴实简单如你和他, 能收 获你们人生中的最美。

亲爱的敬，我们和周芳在首都机场集合并且历尽千辛万苦到达马城的第一天， 是我一辈子都不会忘掉的一幕场景。幸运的是, 我们都没有丢掉彼此, 我们的友 谊在相处过程中从头延续到了现在, 并且定会绵延不绝: 。第一次海牙行, 周芳 带领我开启了欧洲的旅行，再后来我们四个终于圆满完成了意大利的北部观光， 我依然记得我们在米兰的饥饿, 在威尼斯的臭美和在维罗纳的交心。因为见证了 你和伟子的幸福, 更加坚定我对爱情的执着以及信心！敬，你总是如一个沉静的 思考者, 于我, 似姐似妹, 为友为师。感恩有你陪伴, 无论任性时, 高兴时, 失 意时, 抱怨时, 感动时..... 敬, 愿你幸福。

正哥啊, 品睿啊, 相处还未够, 怎就要告别!!! 一开始, 我就知道我们都是 有壁垒的人，但是没想到的是，壁垒之后，我们是如此惺惺相惜的同类好友。不 记得我们是怎么样和何时开始的午餐小聚, 那样的温馨总是让我觉得单调的生活 也可以充满乐趣。作为妹妹, 在你们面前, 我可以做我自己, 说我想说的任何 话, 表达我所有的感情, 那样的感觉多么让我快乐。如老友般, 我们会沿着附近 的小路散步, 评论富贵小区里我们喜欢的车子房子和果子; 如亲人般, 你们让我 在节日里吃各种菜式到肚儿圆圆; 如孩子般, 我们任性交谈, 当然也插科打 诨, “胡说八道”。我最喜欢的字眼是温暖, 因为我觉得这力量最细淢强大, 而 你们, 在这小小的马城, 也是我获得这一力量的坚实依靠。当然, 我希望我也给 予了你们同样的温暖, 就像我从你们那里收获的一样多! 不想说再见, 却就要分 离; 正哥, 品睿, 愿安康, 唯愿安康。

陈方, 方姐姐, 达令, 亲爱的, 我们出乎意料又情理之中的成为了好朋友。 从最初高中时听说的你, 到异国他乡见面用最亲切的乡音问候, 我们人生中最精 彩的四年点点滴滴都分享给了彼此，大到什么是爱国青年，小到 “睡吧”。陈 方, 我们的布达佩斯旅行是多么念念不忘啊, 记忆中最新鲜的是, 旅馆房间门 口, 端着被切好拼盘的十斤大西瓜, 身着粉色长裙的长发的你, 对我笑。可惜, 之后的日程都没有再排开来一场说走就走……方姐姐, 那么多一个人度过的日子 里, 我说我好想说话, 你告诉我, 你在呢; 上一秒, 你问我这条裙子怎么样, 下 一秒, 我说可以考虑但并不完美; 我说那么瘦了不用减肥了, 你说你注意体重保 
持健康。达令, 这四年, 你的每个故事都好精彩, 我多么喜欢这个, 在不停推倒 自己重塑自己的Lady, 在不停寻爱又延伸爱的姑娘。亲爱的, 我们都想抛掉现在 奔向新生活, 而这即将变旧的生活里, 你是我不舍的一部分, 可是, 我知道, 新 生活里的你要幸福, 也会幸福！谢谢你爱我, 我也爱你。

刘同学, 刘轶林, 终于, 你想要的结束、终结, 在这样一个美丽的夏天到来 了: 因为知道你的痛苦与挣扎, 所以特别想为你欣喜欢呼; 因为好奇与祝福, 也 好想知道我认识的了解的那个勇敢无畏的你, 会有怎么样的新生活; 可是, 又因 为四年来一直陪伴的熟悉感, 我发现我竟什么也说不出。长大后, 我学会尽量不 依赖别人、不做戏剧性的吵架与和好, 可是这些还是在 29 岁的时候统统又跑回 来, 跟你。刘轶林, 事儿妈如我, 不喜欢你的 “虚荣” , 苛责你的 “不客气”, 抱怨你的 “自私”，打击你的 “器张”，可是当我写下这段文字的时候，我感谢 你不停地包容, 无尽的鼓舞, 每一天的陪伴, 以及让我成长成熟的支持与力量。 我告诉你, 我从来想不出, 跟你最深刻的一次相处/旅行/谈话...到底是哪一次, 这样听起来，你肯定很伤心，可是我想那是因为四年来我们在彼此生活的每一 天, 而哪一次又是没有你的呢, 所以我说不出, 真的。刘同学, 纵然四年的生活 想起来有些简单清苦, 可是也是你的喜怒哀乐, 塑造了我的自信, 慰藉了我的孤 独, 丰富了我的人生, 我想这也算是一种我想要的相知相惜。祝福的话, 也不必 客套的对你讲, 那就愿再次相见，还能熟悉的挽起彼此的胳膊，咯咯地笑……

最后, 在中国一个小村落里, 我的㸘妈, 我的姐姐姐夫, 我的嘟嘟和果儿, 你 们是我无论在哪儿都能回头看到的光亮, 更是我用尽全力努力奋斗的原因。虽然 二十九年的人生并未有过如何绚烂的骄人成就, 但是在如此平凡平淡的存在中, 我总是感觉自己因为你们收获了好多好多独一无二的幸福和欢乐。㸘妈，感谢你 们的辛劳拼搏让我跟姐姐有了一个富足甚至浪漫的童年, 无论经历多少风雨, 家 都被你们守护着, 春夏秋冬鸟语花香; 每次收到你们发来的照片, 心里唯有感 恩, 感恩安定, 感恩健康, 感恩我们在一起。姐姐姐夫, 你们给全家带来了最最 珍贵的宝贝们, 我相信他们不仅治愈了父母们的失落, 更让每个人得到了不一样 的欢乐与爱; 姐姐姐夫, 生活的压力都被你们承担, 我无法想象换做是自己会有 怎么样的结果, 甚至能不能撑到底都是问题, 妹妹惭愧的同时更加从心底钦佩你 们, 所以妹妹即使学无所成, 也必倾尽全力, 也时刻觉得幸福, 请你们放心。嘟 嘟、果儿, 小姨想对你们说, 也对自己说: 相亲相爱, 心存感恩, 过自己想过的 生活, 就好。

In these four years, though still with "a lot of" shortcomings to work on, I have known myself better and gotten a clear mind in what I want. I am grateful for my choice to meet everyone in my life here! And I am sure that I will appreciate what I have everyday and hold hope for everything upcoming. Finally, I dedicated this book to my sister-Sharon (Xiaowei), who is always there for me with endless love. 虽然越来越了解自己身上的缺 
点短处, 可是我竟越来越满意自己过成现在的样子, 即便有很多遗憾存在, 心中 的美好却不曾减少半分, 我把这一切归功于, 我的姐姐。姐姐, 这本书, 致谢 你，致谢你给予我最无穷的爱。

Xiaoqing Zhu

August 20th,

2016

朱小庆

于2016年8月20日 